\title{
ESTUDO DO POTENCIAL DE DESENVOLVIMENTO DE UM MERCADO FUTURO DE MILHO NO BRASIL
}

\section{EDUARDO LUIS LEÃO DE SOUSA}

Engenheiro Agrônomo

Orientador: Prof. Dr. PEDRO VALENTIM MARQUES

Dissertação apresentada à Escola Superior de

Agricultura "Luiz de Queiroz", Universidade de São Paulo, para obtenção do titulo de Mestre em

Ciências, Área de Concentração: Economia Aplicada.

P I R A C I C A B A

Estado de São Paulo - Brasil

Abril de 1996 
Dados Internacionais de Catalogação na Publicação (CIP)

DIVISÃo DE BIBLIOTECA E DOCUMENTAÇẪO - Campus “Luiz de Queiroz”/USP

Sousa, Eduardo Luis Leão de

Escudo do potencial de desenvolvimento de um mercado futuro

de milho no Brasil / Eduardo Luis Leão de Sousa. - - Piracicaba, 1996.

122p. : il.

Dissertação (mestrado) - - Escola Superior de Agricultura Luiz de Queiroz,

1996.

Bibliografia.

1. Mercado futuro - Desenvolvimento - Brasil 2. Milho - Aspecto eco nômico - Brasil I. Título

CDD 338.17315 


\section{ESTUDO DO POTENCIAL DE DESENVOLVIMENTO DE UM MERCADO FUTURO DE MILHO NO BRASIL}

Eduardo Luis Leão de Sousa

Aprovado em: 10.06.1996

Comissão julgadora:

Prof. Dr. Pedro Valentim Marques

ESALQ/USP

Prof. Dr. Fernando Bento Homem de Melo FEA/USP

Prof. Dr. Flávio Condé de Carvalho

IEA

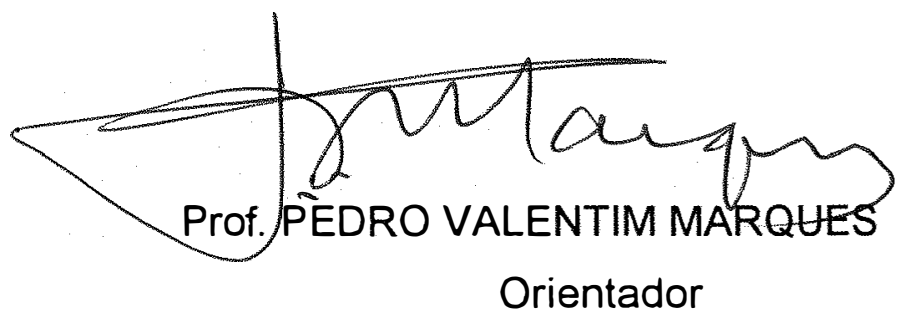


Ao meu pai Eduardo e meu avô Luiz que, muito mais do que seus nomes, me deram inconteste exemplo de caráter, amor e justiça. 
À minha mãe Diva, cuja doce lembrança se completa com a presença da Amanda, que ilumina nossas vidas através de seu afeto, beleza e sabedoria, e a quem, da mesma forma, dedico este trabalho.

Aos irmãos Patricia, Andrea, Valéria, Adriana e Fábio, minha sobrinha Renata e cunhados Dawton e Alexandre, companheiros de todos os momentos e exemplos de união e amor.

À minha avó, pelo seu imensurável afeto, dedicação e incentivo, em todas as fases da minha vida. 


\section{Agradecimentos}

Ao Professor Dr. Pedro Valentim Marques, orientador desta tese, pelo constante apoio, ensinamentos valiosos e pelo exemplo de figura humana digna e pertinaz.

Ao corpo docente do Departamento de Economia e Sociologia Rural DESR/ESALQ e, em especial, aos professores Pedro Carvalho de Mello, Evaristo Marzabal Neves e Ricardo Shirota, pelo incentivo e inúmeras sugestões para o aperfeiçoamento deste trabalho.

À Sra. Doris Gomez Ticerán, pela decisiva contribuição no tratamento estatístico desta dissertação.

Ao Centro de Pesquisa em Economia Agrícola da Fundação de Estudos Agrários "Luiz de Queiroz", pelo relevante auxílio prestado na condução das pesquisas realizadas, através do Prof. Dr. Joaquim Bento de Souza Ferreira Filho.

Aos colegas Engenheiros Agrônomos Luiz Claudio Caffagni e Ana Beatris Penteado Alves, pela amizade, constante estímulo e valiosas sugestões na realização deste trabalho.

Aos colegas do curso de mestrado, especialmente aos amigos Ricardo Luiz Lopes, Thereza Christina Pippa Rochelle, Carlos Estevão Leite Cardoso, José Luiz Parré e Eduardo Spers, pelo companheirismo e constante intercâmbio de idéias e ideais. 
À Sra. Maria Angélica Amado Fanaro e Srta. Luciana Cristina Cipriano, bibliotecárias da Biblioteca do DESR da ESALQ/USP, pela revisão das referências bibliográficas e da estrutura e apresentação desta dissertação.

Aos demais funcionários do DESR, pela atenciosa cooperação e, em especial, às secretárias Cristiane Cipriano, Maria Aparecida Maielli Travalini e Helena Aparecida Cardoso de Oliveira, pela inestimável presteza e dedicação, ao longo de todo o curso.

Ao CNPq, pela bolsa de estudos concedida durante o curso de mestrado e à Fapesp, pelo auxílio financeiro para a realização deste trabalho.

À Bolsa de Mercadorias e Futuros - BM\&F, pela cooperação no fornecimento de brindes para os respondentes da pesquisa. .

Ao zootecnista Marcelo Rolim Fernandes Fontes, amigo fraterno e companheiro constante, pelo permanente apoio e incentivo, e a todos os demais colegas e amigos que, direta ou indiretamente, contribuíram para a conclusão deste trabalho. 


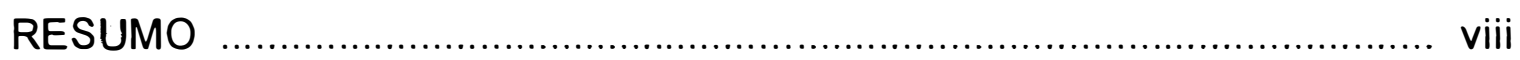

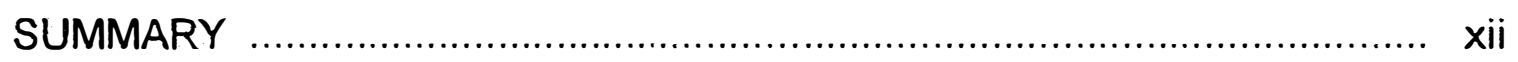

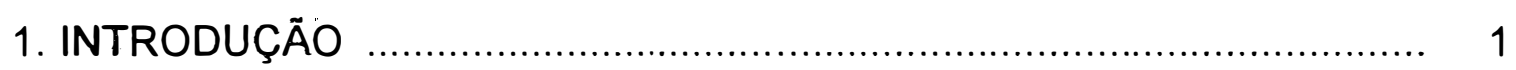

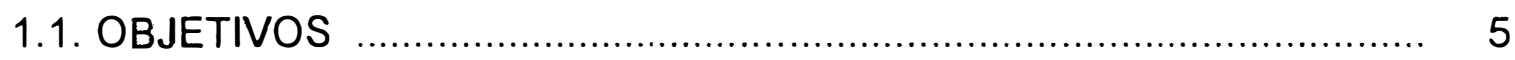

2. A CADEIA AGROINDUSTRIAL DO MILHO ....................................... 7

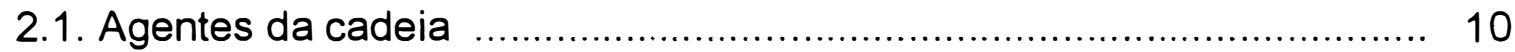

2.1.1. O setor de insumos ............................................................... 10

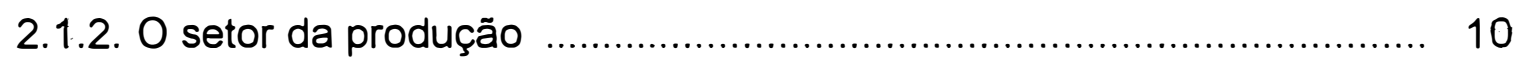

2.1.3. O setor da agroindústria ......................................................... 22

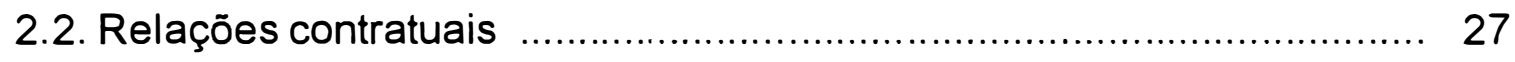

2.3. Comportamento e formação dos preços ............................................ 33

2.3.1. Comportamento dos preços ........................................................ 33

2.3.2. Formação dos preços ............................................................... 36

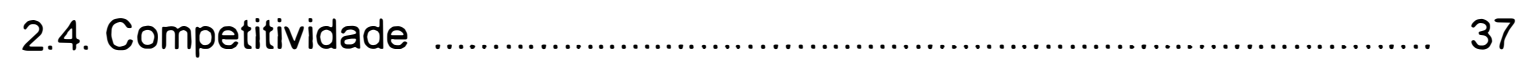

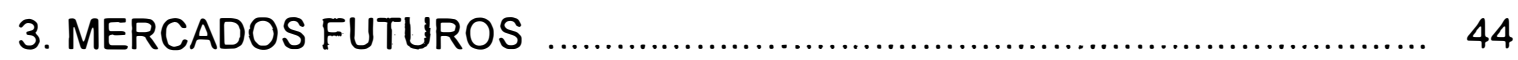

3.1. Condições para o funcionamento do mercado .................................. 46

3.2. Benefícios dos mercados futuros .................................................... 48

3.3. Principais dificuldades para a implantação dos mercados futuros ........ 56

3.4. Aspectos favoráveis .....................................................................6 60

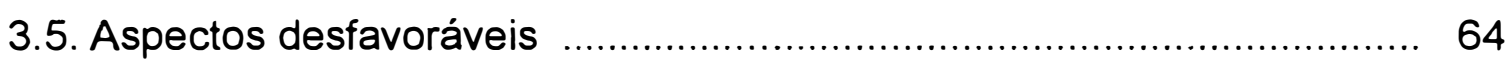

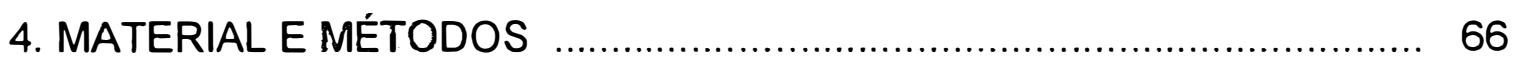

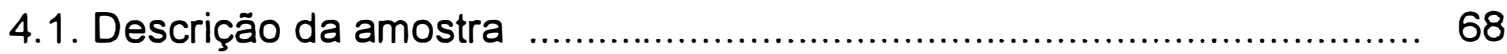

4.2. Descrição do questionário ................................................................ 71

4.3. Condução da pesquisa ................................................................... 71

5. RESULTADOS E DISCUSSÃO …................................................... 73

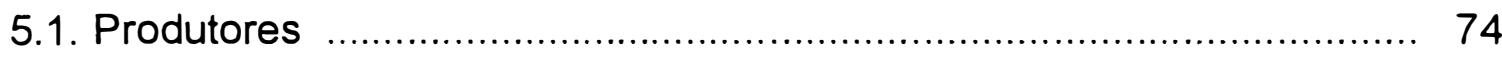




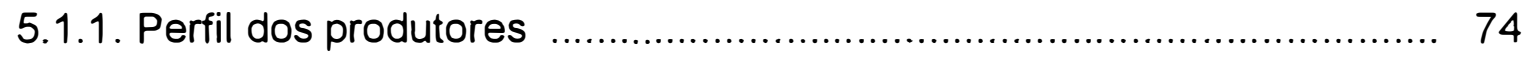

5.1.2. Nivel de conhecimento, motivação e opiniões dos produtores .......... 77

5.2. Traders de cooperativas e agroindústrias ......................................... 83

5.2.1. Perfil dos traders e das empresas .............................................. 83

5.2.2. Opiniões e sugestões dos traders ............................................... 88

5.3. Corretores de Mercados Futuros .................................................... 91

5.3.1. Perfil dos corretores e das empresas ........................................... 91

5.3.2. Opiniões e sugestões dos corretores .......................................... 92

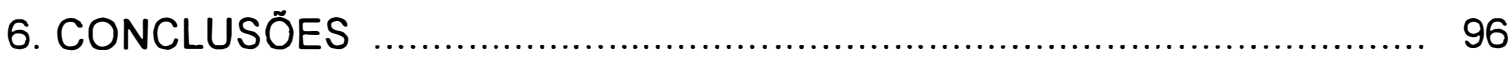

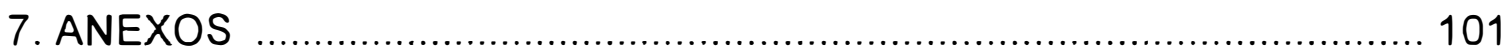

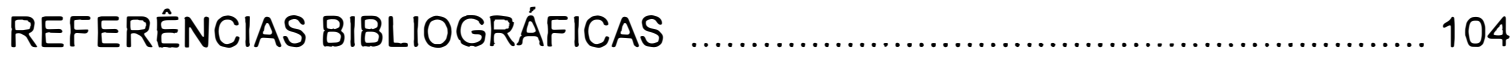

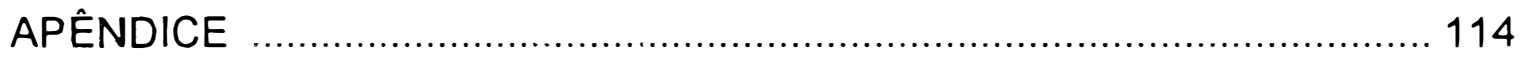




\title{
ESTUDO DO POTENCIAL DE DESENVOLVIMENTO DE UM MERCADO FUTURO DE MILHO NO BRASIL
}

\author{
Autor: EDUARDO LUIS LEÃO DE SOUSA \\ Orientador: Prof. PEDRO VALENTIM MARQUES
}

\section{RESUMO}

Acredita-se que o desenvolvimento de um mercado futuro de milho no Brasil possibilitaria uma minimização de riscos aos agentes envolvidos transferindo-os aos capitais especulativos privados e complementando instrumentos de comercialização que vêm sendo desenvolvidos, como CPR e CM-G. O presente trabalho procurou relacionar as caracteristicas da cadeia agroindustrial do milho com as condições necessárias para a implantação de mercados futuros, os beneficios para os diversos agentes e as possiveis causas de insucesso no desenvolvimento destes mercados. À partir desta análise, pode-se identificar os principais aspectos favoráveis e desfavoráveis para a implantação do mercado futuro de milho no país, que nortearam a pesquisa realizada junto a produtores rurais, traders de agroindústrias e cooperativas e corretores de mercados futuros e onde se procurou identificar as seguintes questões: 1) verificar o nivel de conhecimento e o grau de resistência dos produtores rurais quanto aos mecanismos de mercados futuros; 2) avaliar a importância do papel das Bolsas de Futuros na alavancagem de recursos para financiamentos agrícolas; 3 ) verificar o grau de motivação das corretoras com relação aos mercados futuros agricolas: 4) dimensionar o potencial destes mercados e identificar os principais entraves para o seu desenvolvimento, na 
visão dos atores e 5) propor alternativas, através de sugestões dos agentes envolvidos e a partir de elementos obtidos na revisão literária.

Os resultados da presente investigação permitiram as seguintes conclusões:

- O nivel de conhecimento dos produtores quantos aos mecanismos dos mercados futuros mostrou-se baixo $(51 \%)$, considerando-se que a população considerada era formada por produtores com grande acesso à informação. Pode-se, também, comprovar uma relação direta entre o porte do produtor e o seu nivel de conhecimento. Os produtores se mostraram dispostos a vender parte de sua produção caso houvesse um mercado futuro de milho com transparência e liqüidez.

- Observou-se que as Bolsas de Futuros tem exercido papel importante como instrumento auxiliar na alavancagem de recursos de financiamenta para outras culturas, como a soja, atuando como instrumento de proteção para o setor industrial e exportador e importante referencial de preço para o produtor.

- Os corretores de mercados futuros acreditam no potencial de desenvolvimento dos mercados futuros agricolas e o milho é considerado por estes agentes como a segunda commodity agricola em potencial. No entanto, cerca de $54 \%$ afirmam que, entre as maiores dificuldades para sua implantação, destaca-se o desconhecimento do mercado físico de milho por parte dos corretores.

- Os principais fatores que determinam seu grande potencial. segundo os diversos agentes são o expressivo volume financeiro e físico movimentado pelo setor com grande possibilidade de crescimento, pulverização e diversificação dos mercados de produtores e agroindustrial, alta volatilidade dos preços e a recente estabilização econômica. 
- Quanto aos maiores benefícios e vantagens deste mercado destacam-se a possibilidade de menores riscos aos agentes, funcionando como proteção e sinalização de preços, a diminuição da oscilação de preços ao longo do ano, maiores dificuldades de cartelização na fixação de preços e a possibilidade de alavancagem de recursos para o financiamento de safras agricolas.

- Quanto às maiores restrições a estes mercados destacam-se o desconhecimento dos mecanismos de mercados futuros junto ao meio produtor. assim como dos corretores quanto ao mercado físico, falta de integração e afinidade entre o meio rural e o setor financeiro. constantes intervenções governamentais no mercado e a desuniformidade fiscal e elevada carga tributária.

- Finalmente, são apresentadas uma série de sugestões de ordem educacional, estrutural e operacional. 


\title{
STUDY OF THE POTENTIAL FOR DEVELOPING A FUTURE MARKET FOR MAIZE IN BRAZIL
}

\author{
Author: EDUARDO LUIS LEÃO DE SOUSA \\ Adviser: Prof. PEDRO VALENTIM MARQUES
}

\section{SUMMARY}

It is believed that the development of a future market for maize in Brazil would minimize the risks to the agents involved in its agro-industrial chain, transferring them to speculative private capital and complementing other marketing instruments, such as CPR and CM-G. The present dissertation has attempted to relate the characteristics of the agro-industrial maize chain to the conditions, benefits and causes of the lack of success of the future markets. From these results, the main favourable and unfavourable aspects were identified, which guided the questions approached in the research directed at the principal agents involved. Exploratory research was therefore carried out with rural producers, agro-industrial and cooperative grain traders and future market brokers. An attempt was made to analyse these aspects: 1) check out the level of knowledge and the degree of resistance of the rural producers regarding the mechanisms of both future markets; 2 ) evaluate the importance of the role of the future markets in the leverage of agricultural financing resources; 3 ) check the degree of motivation of the brokers with regard to the agricultural future markets; 4) dimension the potencial of these markets and identify the main hinderances to its development in the view of the agents and 5) propose alternatives, based on suggestions made by the agents involved and from the elements obtained in the literary revision. 
The results of the present investigation permitted the following conclusions:

- The level of knowledge of the producers with regard to mechanism of future markets was shown to be low $(51 \%)$, mainly taking into account that the population considered was made up of producers with great access to information. A direct relationship between the size of the producer and his level of knowledge could also be proved.

- The future markets were observed to have exercised an important role as an auxiliary instrument in the leverage of financing resources for other crops, like soya, acting as an instrument for protecting the industrial sector and exporter, and as an important price referential for the producer.

- Future market brokers believe in the potential for the development of agricultural future markets, and maize is considered by these agents as a second potential agricultural commodity. However, about $54 \%$ affirm that the main factor among the greatest difficulties for its implementation, is the lack of knowledge of the brokers, of the physical maize market.

- The three segments believe in the potencial of the future market for maize in Brazil and the main factors which determine this condition are the expressive possibility for growth, fragmentation and diversification of producers and agroindustrial markets, high volatility of prices and the recent stabilization of the economy.

- As far as the major benefits and advantages of the market are concerned, the three segments pointed out the importance of: the possibility of smaller risks to grain producers and buyers by working as protection and price indicator, the decrease in price fluctuations throughout the year, greater difficulty in the formation of cartels for price fixing and the possibility of leverage of resources for financing agricultural crops.

- As regards the major restrictions to these markets, the three segments pointed out the importance of: the lack of knowledge of the producer community about the mechanisms of future markets and hedging, as well as that of brokers 
concerning the physical market, lack of integration and affinity between the rural community and the financial sector, constant government interventions in the market and the lack of fiscal uniformity and heavy tax load.

- Finally, suggestions of educational, structural and operational order, which have most frequently been put foward among the agents, are submitted. 
1 INTRODUCÃ̃O 


\section{INTRODUÇÃO}

As profundas transformações por que vem passando o Estado brasileiro nos últimos anos, abandonando seu papel intervencionista e regulador na economia brasileira, têm gerado importantes reflexos em todos os setores, inclusive na agricultura. O modelo de política agrícola, baseado quase que exclusivamente no crédito rural e política de garantia de preços mínimos, vem mostrando sinais claros de esgotamento.

O setor agropecuário é caracterizado por apresentar instabilidade de preços, produção e renda em niveis mais elevados que os demais, condição que se torna mais evidenciada na medida em que o Estado sinaliza com o fim da relação paternalista para com a atividade. De fato, desde meados da década de 80 o governo vem diminuindo o volume de subsídio e crédito rural colocados à disposição dos agricultores; na década de 70 os volumes financeiros destinados ao custeio ultrapassavam os 20 bilhões de dólares anuais enquanto nas últimas safras estes montantes não têm ultrapassado os 6 bilhões de dólares. Além da escassez e freqüentes atrasos na liberação de recursos, a falta de definição de regras claras para o setor tem gerado constantes prejuízos ao planejamento e comercialização das safras. Assim, a prolongada crise que o Estado Brasileiro vem sofrendo nos últimos anos associada à falta de uma política agrícola consistente e à transição políticoeconômica por que atravessa o país, determinam condições favoráveis para se tentar desenvolver um novo modelo onde o governo deixa de exercer o papel de principal financiador da agricultura. 
Diante deste quadro, acentuam-se as condições de riscos e incertezas na atividade e caberá ao empresário rural considerar cada vez mais o uso do gerenciamento destes riscos, através da participação no desenvolvimento de instrumentos que possam atenuá-los. Alguns setores agroindustriais mais dinâmicos de produtos de exportação como a soja e a laranja, por exemplo, têm desenvolvido mecanismos de relações contratuais entre os agentes de forma a garantir, de um lado, recursos financeiros ou insumos para a produção e, de outro, matéria-prima para a agroindústria. No caso específico da soja estas transações envolvendo indústrias, exportadoras e produtores, sob a forma de adiantamentos de recursos ou troca de insumos por produto (escambo), representaram em 1993 cerca de 1,3 bilhão de dólares ou quase $50 \%$ da totalidade da necessidade de financiamento do setor.

Paralelamente, vêm surgindo alternativas de alocação dos recursos privados para a agroindústria. Uma delas refere-se à resolução $n^{0} 1.912$ do Banco Central do Brasil que constituiu os fundos de commodities e que visavam à captação de recursos com vistas ao incremento das operações realizadas nos mercados físicos e de liquidação futura de produtos agrícolas, pecuários e agroindustriais. Com a recente extinção destes fundos, iniciaramse estudos para a implantação de novas modalidades de aplicações financeiras como o fundo verde". Além destes, outros mecanismos de autofinanciamento do setor têm surgido, como títulos representativos de mercadorias para entrega futura como o CM-G (Certificado de Mercadoria com Emissão Garantida) e CPR (Cédula de Produto Rural).

Desta forma, nota-se que o desenvolvimento agrícola do Brasil passa necessariamente pela iniciativa privada criando mecanismos para seu financiamento e este desenvolvimento será mais consistente e duradouro se menos expostos a riscos estiverem seus agentes. A criação e fortalecimento de um mercado futuro das principais commodities no Brasil possibilitaria uma minimização de riscos a compradores e vendedores destes produtos, 
transferindo-os aos capitais especulativos privados, através de um mercado liquido e transparente.

Dentre estas commodities optou-se por estudar o potencial de desenvolvimento do mercado futuro do milho já que sua cadeia agroindustrial é uma das que mais se destaca, não só pela sua grande importância econômica como por se constituir numa ponderável fonte de energia na alimentação humana e animal. Segundo MELO (1996), o milho foi a cultura com maior receita agrícola em 1995; seu valor de produção neste ano foi de 4,406 bilhões de reais, seguido pela soja com 4,092 bilhões, cana-de-açúcar com 3,892 bilhões e laranja com 2,815 bilhões de reais. Além disso, a produção deste cereal tem aumentado muito nestes últimos anos com a incorporação de novas áreas, além da obtenção de expressivos ganhos de produtividades através de inovações tecnológicas, fazendo com que o milho deixe de ser uma cultura basicamente de subsistência passando a apresentar significativo caráter comercial.

Quanto à sua importância no consumo, o milho apresenta várias utilizações, sendo que a principal delas é como matéria-prima na formulação de ração animal, constituindo-se na mais importante fonte de energia na alimentação de aves, suínos e bovinos, cujo setor movimenta cerca de 3,0 bilhões de dólares anuais. É também muito utilizado na alimentação humana, sob a forma de farinha, fubá, óleo, xarope etc. e em certas regiões do Brasil constitui-se na principal fonte alimentar na dieta da população.

No seu desenvolvimento, o presente trabalho foi então dividido em cinco partes. A primeira delas trata (mediante uma análise descritiva) das principais características da cadeia agroindustrial do milho, seus principais agentes, suas relações contratuais, o comportamento e formação de preços e a sua competitividade frente aos principais paises produtores e exportadores. A segunda parte analisa, com base em uma revisão bibliográfica de fontes nacionais e internacionais, os benefícios e as causas de insucesso dos mercados futuros, procurando sempre associá-los às caracteristicas da cadeia 
do milho. A partir destes resultados identificaram-se os principais aspectos favoráveis e desfavoráveis, os quais nortearam as questões abordadas na pesquisa conduzida junto aos principais agentes envolvidos. A descrição da metodologia é discutida na terceira parte do trabalho. A quarta parte destinase à apresentação dos resultados e discussões desta pesquisa e, finalmente, na quinta parte apresentam-se as conclusões do presente trabalho e sugestões para a criação e o desenvolvimento deste mercado.

\subsection{Objetivos}

O objetivo deste trabalho é analisar o potencial do desenvolvimento de um mercado futuro de milho, dadas as características deste mercado, supostos benefícios e dificuldades para sua implantação.

A partir de questionários dirigidos aos diversos segmentos envolvidos, são analisados cinco aspectos considerados relevantes para os resultados do estudo:

- verificar o nível de conhecimento e o grau de resistência dos produtores rurais quanto aos mecanismos de mercados futuros e hedge;

- avaliar a importância do papel das Bolsas de Futuros na alavancagem de recursos para financiamentos agrícolas;

- verificar o grau de motivação das corretoras com relação aos mercados futuros agrícolas, com ênfase para o milho;

- dimensionar o potencial destes mercados e identificar os principais entraves para o seu desenvolvimento, na visão dos atores e

- propor alternativas, através de sugestões dos agentes envolvidos e a partir de elementos obtidos na revisão da literatura.

Pretende-se, assim, dar uma contribuição ao desenvolvimento destes mercados, no sentido de se detectar as razões de alguns de seus principais entraves a partir dos resultados dos questionários obtidos junto àqueles agentes e do estudo teórico e assim sugerir soluções para o desenvolvimento 
de um mercado futuro de milho. Acredita-se que o seu desenvolvimento em muito poderá auxiliar na restruturação dos mercados agrícolas do Brasil fortalecendo o setor através do aperfeiçoamento dos contratos entre os agentes e possibilitando assim uma maior eficiência na cadeia agroindustrial do milho. 
2 A CADEIA AGROINDUSTRIAL

DO MILHO 


\section{A CADEIA AGROINDUSTRIAL DO MILHO}

Cadeia agroindustrial pode ser definida como uma seqüência de operações interdependentes que têm por objetivo produzir, modificar e distribuir um produto (DAVIS \& GOLDBERG, 1957). Dentro desta visão sistêmica, também chamada de agribusiness, torna-se cada vez mais clara a intima relação que envolve seus agentes que desempenham funções que vão desde a produção de insumos até a produção, processamento, distribuição e comercialização de produtos agrícolas. É importante salientar que atualmente a soma das atividades realizadas fora da fazenda são consideravelmente maiores que o total das operações nela realizadas. ARAÚJO et al. (1990) estimam que no Brasil o total das operações ligadas ao complexo agropecuário se distribua da seguinte forma: $8 \%$ de bens e serviços dirigidos ao mercado rural, "antes" da fazenda; $32 \%$ de produção agropecuária propriamente dita; e $60 \%$ "depois" da porteira. O valor agregado do complexo, em torno de US\$ 180 bilhões, representa aproximadamente $1 / 3$ do PIB nacional.

No caso específico do milho, pode-se fazer uma representação gráfica destes setores e suas relações, conforme figura 1. A seguir será feita uma análise de cada um destes agentes, suas relações contratuais, formação e comportamento de preços; posteriormente, uma abordagem sobre a competitividade desta cadeia frente aos demais países. 


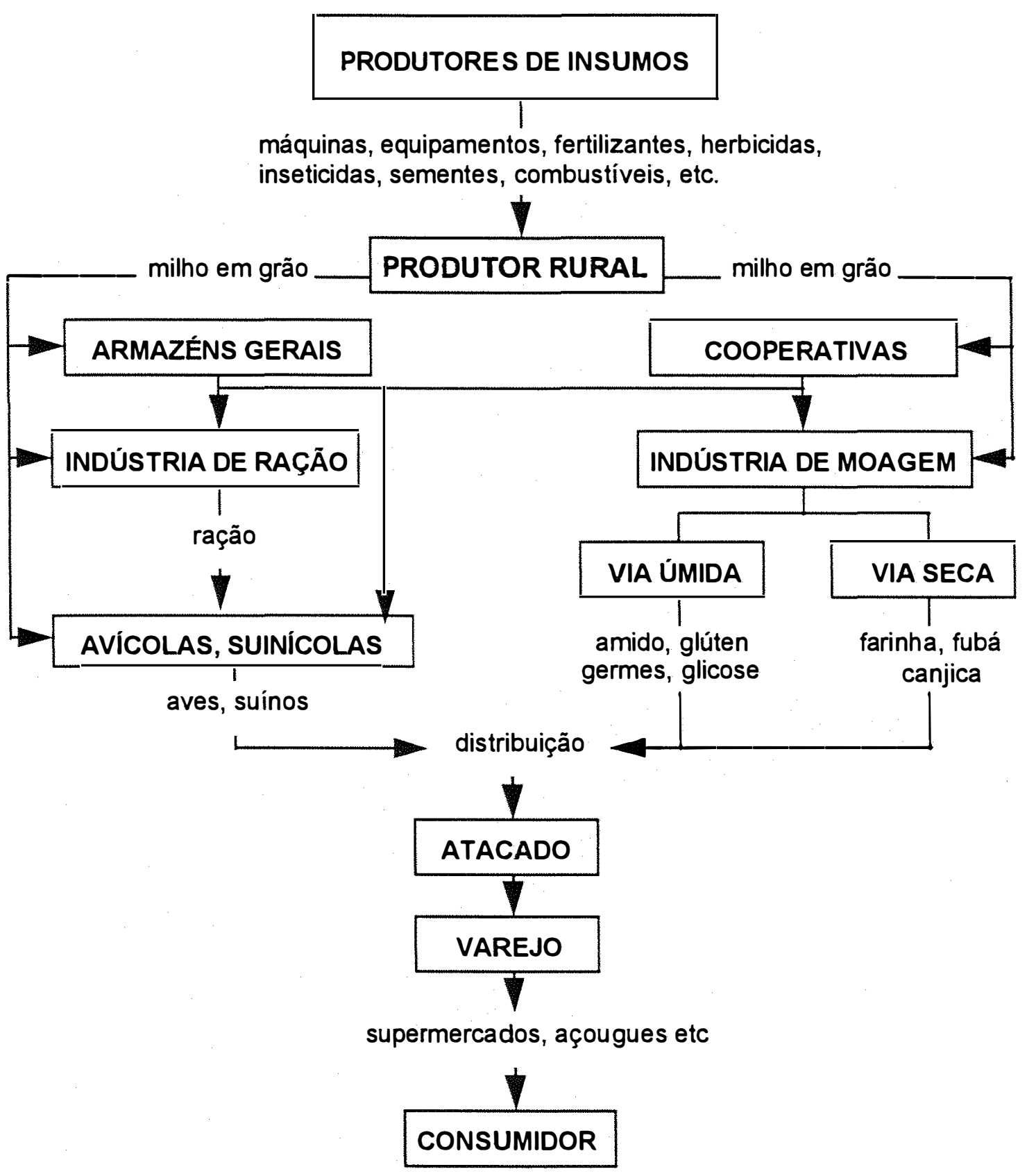

Figura 1. Fluxograma da cadeia agroindustrial do milho. 


\subsection{Agentes da cadeia}

\subsubsection{O setor de insumos}

Destacam-se como categorias básicas de insumos do milho as seguintes: terra, mão-de-obra, sementes, máquinas e implementos agrícolas, fertilizantes e defensivos. Quanto à estrutura de mercado destes setores, de um modo geral caracteriza-se por apresentar um alto índice de concentração, como no caso de máquinas onde apenas duas empresas de colheitadeiras e sete de trator atuam no mercado de modo significativo (SOUZA \& SANSON, 1993, p. 47).

Em propriedades que se utilizam de alto nivel tecnológico, os fertilizantes representam o mais importante item do custo de produção. Segundo dados do Anuário Estatístico do Setor de Fertilizantes de 1994, o uso de fertilizantes para o milho ainda é muito baixo, se comparado com a recomendação técnica média para a cultura. No entanto, nota-se um sensivel aumento da utilização deste insumo nos últimos anos, denotando preocupação por parte dos produtores em se obter ganhos de produtividades através de incorporações tecnológicas. Assim, conforme a tabela 1, pode-se verificar que entre as safras de 1990 e 1994 houve um expressivo crescimento médio na utilização deste insumo para o cultivo de milho, por hectare, da ordem de $14,47 \%$ ao ano.

\subsubsection{O setor da produção}

O Brasil é o terceiro pais em termos de produção agrícola, ficando atrás dos EUA e China; apresenta, porém, produtividade média bastante baixa, em torno de $2.197 \mathrm{~kg} / \mathrm{ha}$ nas safras entre 1991 e 1995, contra uma produtividade média mundial de $3.881 \mathrm{~kg} / \mathrm{ha}$ no mesmo período e ficando em quinto lugar se considerada a média dos seis maiores países produtores (tabela 2). SANTO et 
al. (1994) constataram no entanto que, apesar de bem mais baixa, a evolução da produtividade de milho no Brasil é mais rápida que a americana e a argentina, considerando-se o período 1975-93. Aparentemente, as margens para o aperfeiçoamento técnico da cultura são maiores no Brasil do que naqueles paises, o que contribui para explicar condições mais favoráveis para o maior incremento de rendimento a curto prazo.

Tabela 1 - Consumo de fertilizante para a cultura do milho (safras 1991-94).

\begin{tabular}{cccc}
\hline ano & $\begin{array}{c}\text { área } \\
(1.000 \mathrm{ha})\end{array}$ & $\begin{array}{c}\text { consumo total } \\
(1.000 \mathrm{t})\end{array}$ & $\begin{array}{c}\text { consumo por área } \\
(\mathrm{kg} / \mathrm{ha})\end{array}$ \\
\hline 1990 & 13.636 & 1.300 & 95,14 \\
1991 & 14.135 & 1.500 & 106,12 \\
1992 & 12.921 & 1.600 & 123,83 \\
1993 & 13.151 & 1.910 & 145,24 \\
1994 & 14.539 & 2.325 & 159,91 \\
\hline
\end{tabular}

Fonte: IBGE/empresas do setor.

Tabela 2 - Produção e produtividade médias dos principais paises produtores de milho (em mil te $\mathrm{kg} / \mathrm{ha}$, respectivamente) entre as safras de 1991 a 1995 .

\begin{tabular}{lrc}
\hline \multicolumn{1}{c}{ país } & produção média & produtividade média \\
\hline EUA & 209.537 & 7.541 \\
China & 99.538 & 4.709 \\
Brasil & 29.266 & 2.197 \\
México & 15.720 & 2.052 \\
França & 12.950 & 7.417 \\
Argentina & 9.780 & 4.179 \\
outros & 127.504 & - \\
& & \\
total & 504.295 & 3.881 \\
\hline
\end{tabular}

Fonte: USDA - Departamento de Agricultura dos Estados Unidos 
Em relação à produção brasileira, pode-se detectar que a região CentroSul é responsável por quase $75 \%$ da área plantada de milho no Brasil quando considerada a média das safras entre 1984 e 1995 e pela produção de 91,66\% no período. As regiões que apresentam maiores índices de produtividade são, pela ordem Centro-Oeste, Sul, Sudeste, Nordeste e Norte (tabela 3, elaborada a partir dos apêndices 1,2 e 3 ).

Tabela 3 - Produção, área e produtividade médias de milho no Brasil por regiões (1984-95).

\begin{tabular}{lrrrrrr}
\hline \multicolumn{1}{c}{ Produção } & \multicolumn{2}{c}{ Area } & \multicolumn{2}{c}{ Rendimento } \\
\multicolumn{1}{c}{ região } & \multicolumn{1}{c}{$(\mathrm{t})$} & \multicolumn{1}{c}{$(\mathrm{h})$} & \multicolumn{1}{c}{$(\mathrm{ha})$} & \multicolumn{1}{c}{$(\%)$} & $(\mathrm{kg} / \mathrm{ha})$ & indice \\
\hline Sul & 12.792 .882 & 48,33 & 5.220 .332 & 39,80 & 2.438 & 121,2 \\
Sudeste & 7.269 .658 & 27,46 & 3.003 .116 & 22,90 & 2.417 & 120,2 \\
Centro-Oeste & 4.203 .467 & 15,88 & 1.543 .904 & 11,77 & 2.678 & 133,2 \\
Nordeste & 1.616 .642 & 6,11 & 2.936 .628 & 22,39 & 545 & 27,1 \\
Norte & 588.751 & 2,22 & 412.350 & 3,14 & 1.408 & 70,0 \\
& & & & & & \\
Total & 26.471 .401 & 100,00 & 13.116 .329 & 100,00 & 2.011 & 100,0 \\
\hline
\end{tabular}

Fonte: IBGE, CONAB.

A tabela 4 e as figuras 2,3 e 4 (também elaboradas a partir dos apêndices 1,2 e 3 ) onde, para efeito de melhor visualização e pela sua significativa importância, foram consideradas apenas as regiões do Centro-Sul, mostram a dinâmica da cultura do milho no Brasil e permitem traçar sobre ela algumas considerações:

O Brasil tem apresentado expressivo crescimento de produção de milho no decênio 1985-94 (calculada a partir de médias móveis centradas trienais e utilizando-se o método dos mínimos quadrados, como instrumental para se calcular a taxa geométrica de crescimento) de $4,17 \%$ a.a. sendo que a maior parte deste crescimento é explicada pelos ganhos de produtividade no período, de $3,64 \%$ a.a., contra $0,52 \%$ a.a. correspondente ao aumento de área. A cultura do milho no Brasil apresenta ainda sistemas de produção bastante 
heterogêneos, sendo cultivada seguindo diversos pacotes tecnológicos e por diferentes níveis de agricultor, o que permite ainda expressivos ganhos de produtividade na medida em que aumenta sua exploração à nível comercial.

Tabela 4 - Taxa de crescimento médio anual de milho no Brasil por regiões (1985-94), em porcentagem.

\begin{tabular}{lccc}
\hline região & $\begin{array}{c}\text { Quantidade } \\
\text { produzida }(\mathrm{Q})\end{array}$ & $\begin{array}{c}\text { Area } \\
(\mathrm{A})\end{array}$ & $\begin{array}{c}\text { Produtividade } \\
\text { (Q/A) }\end{array}$ \\
\cline { 2 - 4 } Sul & 4,80 & 0,59 & 4,18 \\
Sudeste & 2,72 & 0,45 & 2,26 \\
Centro-Oeste & 5,72 & 1,93 & 3,72 \\
Nordeste & 0,88 & $-0,93$ & 1,82 \\
Norte & 8,11 & 6,13 & 1,86 \\
& & & \\
Brasil & 4,17 & 0,52 & 3,64
\end{tabular}

Obs.: Cálculos realizados a partir de médias móveis trienais. Fontes: IBGE, CONAB

À nivel de regiões, pode-se perceber um sensivel aumento de produção na região Centro-Oeste também chamada de tegião de fronteira", apresentou, no período, o maior crescimento de produção $(5,72 \%$ a.a. ), o maior aumento de área plantada de milho ( $1,93 \%$ a.a.) e o segundo maior crescimento de produtividade, ficando atrás da região Sul. Este crescimento de área se deu principalmente pela incorporação de novas áreas de cerrado na década de 80 e a partir da rotação de cultura com a soja em função de aspectos técnicos (ocorrência de doenças e nematóides entre outros) e econômico-financeiros (altos custos de frete até os portos, falta de financiamentos oficiais para a soja etc.). Esta região, então, caracteriza-se por apresentar propriedades agrícolas com grandes extensões de terra permitindo economias de escala e alto nível de mecanização e tecnologia voltadas para a exploração comercial, o que ajuda a explicar a sua alta produtividade com ganhos progressivos nos últimos dez anos (3,72\% a.a.). De fato, MORICOCHI et al. (1989) concluíram que a 
produtividade do milho aumenta à medida que se aumenta a magnitude da área do imóvel e que, ao contrário das pequenas propriedades, em que a cultura de milho tem caráter mais de subsistência, nas maiores propriedades ela assume característica mais comercial, ou seja, a produção está mais voltada para o atendimento do mercado, o que só é viabilizado com a incorporação de melhores técnicas de produção.

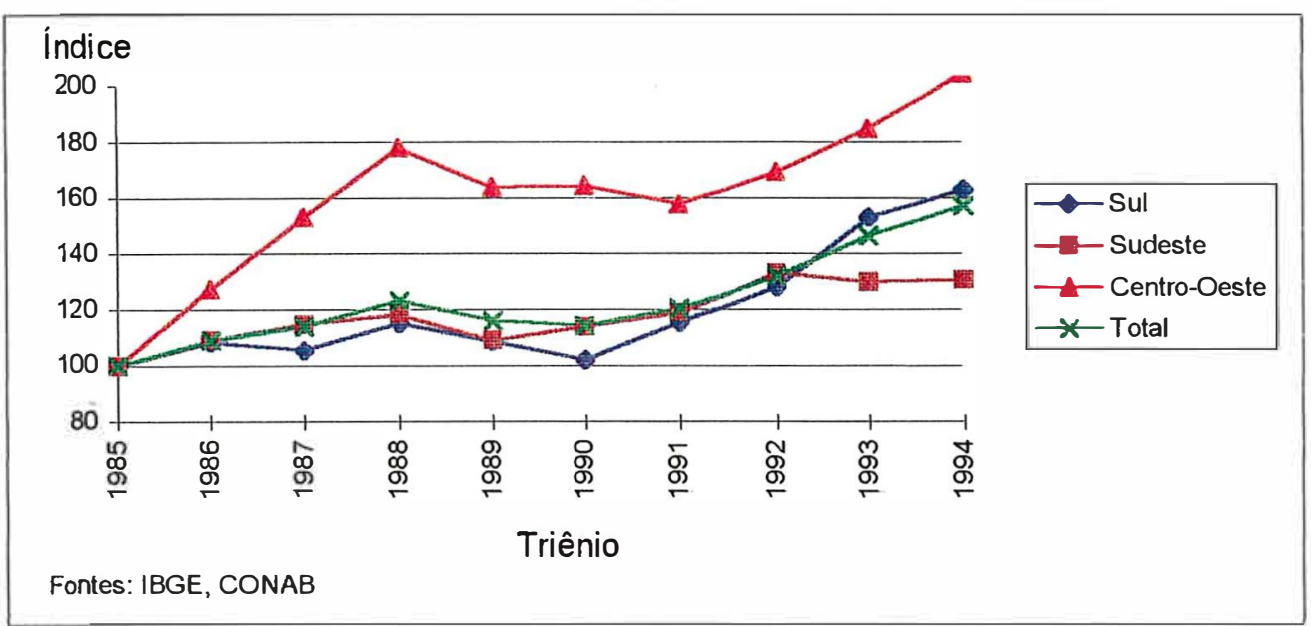

Figura 2. Índice de produção de milho no Brasil, por regiões (1985-94) médias móveis trienais.

Em segundo lugar em termos de crescimento de produção, destaca-se a região Sul pelo seu também expressivo crescimento $(4,80 \%$ a.a.) através principalmente do aumento de produtividade $(4,18 \%$ a.a. $)$, além de contribuir com a maior parcela de produção do grão no país. Paralelamente, ocorre ainda aumento de área $(0,59 \%$ a.a. $)$, o que contradiz a visão de que o Brasil Central teria sido e seria para o futuro a única opção de expansão de áreas cultivadas. Segundo MARTIN \& GONÇALVES (1995) as fronteiras internas da região Sul e Sudeste são bastantes expressivas e haveriam cerca de 100 milhões de hectares de pastagens cuja substituição parcial por lavouras poderia dobrar a área cultivada destas últimas. Em outras palavras a 
intensificação do uso da terra no conjunto dessas duas regiões já dotadas de infra-estrutura representa uma monumental fronteira agrícola a ser ocupada.

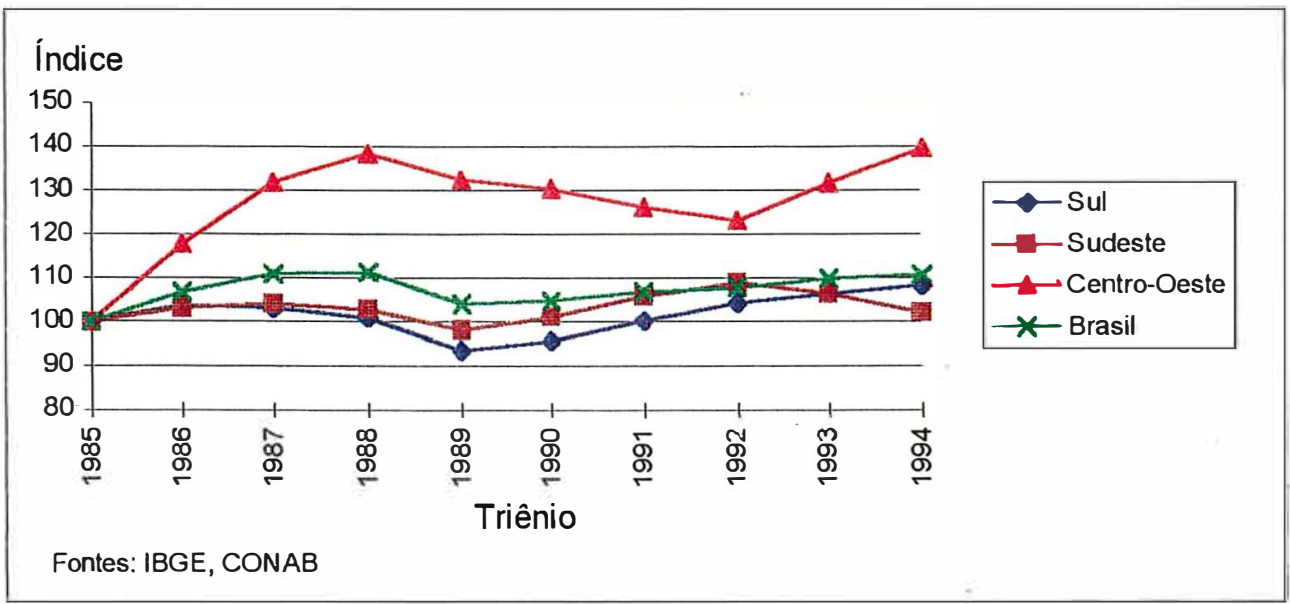

Figura 3. Índice de área plantada de milho no Brasil, por regiões (1985-94) médias móveis trienais.

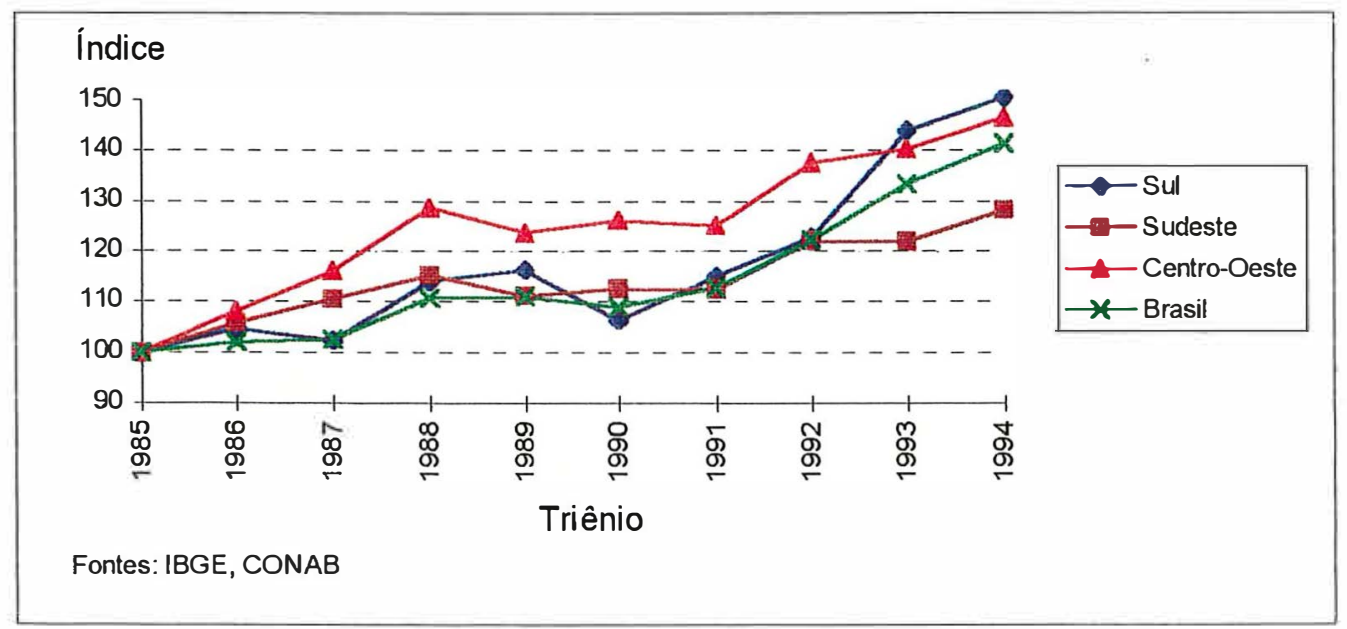

Figura 4. Índice de produtividade de milho no Brasil, por regiões (1985-94) médias móveis trienais. 
A região Sudeste apresentou também consideráveis ganhos de produção (2,72 \% a.a.), produtividade (2,26 \% a.a.) e, em menor dimensão, de área $(0,45 \%$ a.a.). Segundo MARTIN \& GONÇALVES (1995) o milho é a principal cultura em termos de área de lavoura da região no período de 1970 a 1993. Além de estar presente em grande número das propriedades como segunda ou terceira atividade agrícola, à exceção das regiões de monocultura de cana e laranja, ela apresenta zonas de produção em que o milho tem o perfil de cultura principal realizada com elevado nível tecnológico com a obtenção de altos niveis de produtividade. Complementando esta conclusão PIVA et al. (1990) afirmam que a retenção para autoconsumo do milho produzido nas propriedades agrícolas do Estado de São Paulo, variou de 69,9\% em 1963/64 a $21,6 \%$ em 1988/89, notando tendência declinante nessa retenção, indicativo de maior destinação do produto para o mercado e, em última análise, uma maior integração do produtor na agroindústria do milho.

Estas observações nos permitem depreender que a produção de milho no Brasil tende a ter um caráter mais comercial, na medida em que têm sido empregados maiores esforços para se elevar a produtividade e que percebe-se um aumento da demanda por este produto. MELO (1991) constata que as possibilidades de crescimento da agropecuária nos próximos anos superam o crescimento que ocorreu nos anos 80 , com possivel crescimento agrícola no intervalo de $3,8 \%$ a $5,3 \%$ ao ano, enquanto que na década passada registrou aumento de $3,2 \%$ ao ano em média. Uma análise sobre o potencial de crescimento da demanda de milho, em função da baixa renda e desnutrição com que convive a população brasileira será apresentada no próximo item.

\subsubsection{Condições de demanda}

Neste item são abordadas questões relativas às condições de demanda do milho, tanto no que tange aos segmentos e regiões consumidoras mais importantes como ao tamanho deste mercado. 
O milho é o cereal que apresenta a mais diversificada utilização na alimentação humana e animal, com mais de 500 derivados, muitos dos quais se prestam a diversos empregos em diferentes indústrias:

- Alimentícia e química: amido, dextrina, glicose, óleo, margarina, fermento, geleia, sorvetes, enlatados, mel glicosado, flocos, farinha, vinagre etc;

- Bebidas: licores, refrigerantes, uísque, gim, vodka, cerveja, champanha, vinhos etc;

- Fermentação: enzimas, acetonas, butanol, isopropanol, metanol, agente para fermentação, glicerina, ácido láctico etc;

- Química e mecânica: fundição de metais, explosivos, plásticos, tecidos, papel e papelão, combustível, cola, cosméticos, sabões etc;

- Rações: é misturado à ração sob diversas formas: como grão moído integralmente, farelo (derivado do resíduo da extração de óleo de milho), germe (extraído do milho integral), protenose e refasil (subprodutos das refinações de milho).

Grande parte da produção do milho é autoconsumida nas propriedades, o que dificulta os levantamentos sobre os usos do cereal. Por conta disso, encontram-se na literatura várias estimativas, nem sempre consistentes entre si. Uma das estimativas é apresentada na tabela 5. Nela observa-se que o consumo nas próprias unidades e perdas representa cerca de $38 \%$ da produção total. O consumo animal consome quase metade, $48,58 \%$, e moagem cerca de $13 \%$.

Uma outra forma de cálculo seria através da apuração dessas estimativas através dos respectivos setores. Assim, no caso das rações podese estimar o consumo de matérias-primas para sua fabricação em função das projeções de produção do complexo dos produtos de origem animal (CPOA). A Associação Nacional dos Fabricantes de Rações - ANFAR (1993b), através de metodologia específica, parte das projeções de produção potencial de carne de frango, suíno, ovos e leite, segundo entidades representativas de cada setor e 
retroage até o nível de consumo de rações, estimado com base nas conversões alimentares. A partir daí, estima o consumo de cada matéria-prima através de suas concentrações em fórmulas de rações equivalentes. Desta forma estimou o consumo de milho no CPOA em 1993, correspondendo a $39,31 \%$ do consumo total estimado pela CONAB/DIPLA naquele ano. Segundo esta estimativa, o consumo de milho em rações para o setor avícola é praticamente o dobro de sua destinação para rações utilizadas no setor suinícola.

Tabela 5 - Consumo do milho no Brasil, por segmento (em mil t), 1993.

\begin{tabular}{lrr}
\hline segmento & consumo & \multicolumn{1}{l}{ (\%) } \\
\hline autoconsumo e perdas & 11.685 & 37,97 \\
avicultura & 8.485 & 27,57 \\
suinocultura & 4.849 & 15,76 \\
outros animais & 1.616 & 5,25 \\
moagem & 3.940 & 12,8 \\
sementes & 200 & 0,65 \\
& & \\
total & 30.775 & 100,00 \\
\hline
\end{tabular}

Fonte: CONAB

Outro setor importante no consumo do milho é o de moagem úmida que, segundo empresas do setor, consome cerca de 1.200.000 t/ano. No caso da moagem seca, estima-se que sua demanda de matéria-prima tenha representado cerca de 2.740 .000 t para o ano de 1993 .

Em relação à demanda para sementes, segundo dados da ABRASEM, (TROMBETA, 1994), o consumo de semente de milho na safra de 1992/93 foi de $147.933 \mathrm{t}$.

Desta forma, baseado nestas informações, pode-se elaborar a tabela 6.

Interessante estudo foi efetuado pela ANFAR (1993a), no que diz respeito ao cálculo do diferencial entre o alimento consumido e o mínimo necessário segundo recomendações de alimentação da Food and Agriculture Organization (FAO), procurando assim demonstrar as necessidades para se 
eliminar a fome do país e o potencial de consumo de diversos produtos, entre eles o milho, conforme a tabela 7 . Nela, pode-se perceber que, ao se comparar o consumo atual e o mínimo recomendado para os casos do leite, ovos, frango e suinos, poder-se-ia atingir um incremento na área de plantio para o milho da ordem de 1.600 .000 ha, o que corresponde a uma produção adicional de $3.550 .000 \mathrm{t}$, geração de 40.000 novos empregos e um considerável aumento no consumo de fertilizantes, ressalvando-se que a média de consumo nacional de frango já supera a recomendada e supondo-se que não haveria alteração neste consumo.

Tabela 6 - Estimativa de consumo de milho por segmento no Brasil (1993).

\begin{tabular}{lrr}
\hline segmento & \multicolumn{1}{c}{$\mathrm{t}$} & \multicolumn{1}{l}{$(\%)$} \\
\hline consumo comercial & 16.188 .542 & 52,59 \\
aves (corte) & 5.907 .063 & 19,19 \\
aves (postura) & 1.916 .278 & 6,23 \\
suinos & 4.078 .811 & 13,25 \\
bovinos & 198.457 & 0,64 \\
moagem seca & 2.740 .000 & 8,90 \\
moagem úmida & 1.200 .000 & 3,90 \\
sementes & 147.933 & 0,48 \\
consumo rural e perdas & 14.586 .458 & 47,41 \\
consumo total & 30.775 .000 & 100,00 \\
\hline
\end{tabular}

Fontes: ANFAR/ABRASEM/Empresas do setor de moagem/CONAB/DIPLA.

Quanto ao tamanho deste mercado, observa-se na tabela 8, que o Brasil é praticamente auto-suficiente no que diz respeito ao consumo de milho, não exportando o produto desde 1984 e efetuando importações esporádicas e localizadas, principalmente nas regiões Nordeste e Sul, basicamente da Argentina que representam menos de $3 \%$ da produção na média. Constata-se também que os estoques de passagem situam-se em torno de $10 \%$ da produção na média ou consumo equivalente a pouco mais de um mês. 
Tabela 7 - Diferencial entre o alimento consumido em 1992 e mínimo necessário.

\begin{tabular}{lcccc}
\hline $\begin{array}{c}\text { produto/ } \\
\text { unidade }\end{array}$ & $\begin{array}{c}\text { consumo per } \\
\text { capita/ano }\end{array}$ & recomendado & $\begin{array}{c}\text { produção } \\
\text { adicional }\end{array}$ & $\begin{array}{c}\text { área adicional } \\
\text { para milho (ha) }\end{array}$ \\
\hline leite (litro) & 96,8 & 216 & 24,94 bilhōes & 151.892 \\
ovos (dúzia) & 7,7 & 18 & 1,574 bilhões & $867.961,10$ \\
frango(kg) & 18,8 & 14,4 & - & - \\
suíno $(\mathrm{kg})$ & 7,8 & 10,5 & 412.703 & $363.266,60$
\end{tabular}

milho na ração e

sementes

\begin{tabular}{|c|c|c|c|c|}
\hline $\begin{array}{l}\text { produção } \\
\text { adicional (t) }\end{array}$ & $\begin{array}{l}\text { produção } \\
\text { nacional (t) }\end{array}$ & $\begin{array}{c}\text { área adicional } \\
\text { (ha) }\end{array}$ & $\begin{array}{l}\text { mão de obra } \\
\text { adicional }\end{array}$ & $\begin{array}{c}\text { fertilizantes } \\
(\mathrm{t})\end{array}$ \\
\hline $3.552 .577,70$ & 31.382 .600 & $1.646 .236,20$ & 40.458 & $757.268,70$ \\
\hline Fontes: ANFAR/ & Associação & aulista de Avicl & $(A P A) /$ As & Brasileira \\
\hline
\end{tabular}

No que tange à distribuição regional deste consumo, São Paulo e Santa Catarina destacam-se como sendo os maiores importadores do grão, enquanto Paraná e Goiás, os maiores exportadores. Rio Grande do Sul e Minas Gerais aparecem com produções praticamente equivalentes ao consumo no ano de 1994, conforme tabela 9. 
Tabela 8 - Balanço de oferta e demanda de milho entre 1983 e 1995 (em mil t).

\begin{tabular}{|c|c|c|c|c|c|c|c|}
\hline safra & $\begin{array}{c}\text { qtde } \\
\text { inicial }\end{array}$ & produção & import. & suprim. & consumo & export. & $\begin{array}{c}\text { estoque } \\
\text { passagem }\end{array}$ \\
\hline $82 / 83$ & $1.823,4$ & $.014,1$ & 213,1 & $21.050,6$ & $19.461,2$ & 765,9 & 823,5 \\
\hline $83 / 84$ & 823,4 & $21.177,5$ & 253,6 & 54,5 & 55,4 & 178,2 & $2.120,9$ \\
\hline $84 / 85$ & $2.121,0$ & 3,9 & 262,1 & 7,0 &, 0 & 0,0 & 600,0 \\
\hline $85 / 86$ & 600,0 & $20.264,1$ & $2.423,6$ & 87,7 & & 0,0 & 0,1 \\
\hline $86 / 87$ & $1.600,1$ & $26.758,3$ & 871,2 & $29.229,6$ & 26 & 0,0 & \\
\hline $87 / 88$ & $2.879,4$ & 3,6 & 5,0 & $28.118,0$ & 20,0 & 0,0 & 98,0 \\
\hline $88 /$ & $2.798,0$ & & 4,9 & & & 0,0 & 15,1 \\
\hline $89 / 5$ & $3.079,7$ & 22 & 700,0 & 7,1 & & 0,0 & 1.237 \\
\hline $90 / 91$ & $1.237,1$ & 24. & 832,2 & 0,7 & 8,0 & 0,0 & 822,7 \\
\hline $91 / 92$ & 822,7 & $30.770,8$ & 340,0 & 33,5 & 10,0 & 0,0 & $3.433,5$ \\
\hline $92 / 93$ & $3.488,7$ & 7,4 & & 4,0 & & 0,0 & 19,0 \\
\hline & $3.419,0$ & & & & & 0,0 & \\
\hline $94 / 95_{(2)}$ & $5.425,0$ & 15,0 & 600,0 & 40,0 & 0,0 & 0,0 & 0,0 \\
\hline média & $2.316,73$ & $25.841,83$ & 748,32 & $28.906,88$ & $26.101,26$ & 72,62 & 2.732, \\
\hline
\end{tabular}

Fonte:CONAB/DIPLA

(1)Estimativa $\quad$ (2) Projeção

Tabela 9 - Produção e consumo estimados de milho por Estado (safra 1994).

\begin{tabular}{lrrrrr}
\hline Estado & \multicolumn{2}{c}{ produção } & \multicolumn{2}{c}{ consumo } & \multicolumn{1}{c}{ saldo } \\
& \multicolumn{1}{c}{$\mathrm{t}$} & \multicolumn{1}{c}{$(\%)$} & \multicolumn{1}{c}{$(\mathrm{t})$} & \multicolumn{1}{c}{$(\%)$} & \multicolumn{1}{c}{$(\mathrm{t})$} \\
\hline São Paulo & 3.136 .230 & 9,49 & 6.245 .800 & 19,16 & -3.109 .570 \\
Sta. Catarina & 3.303 .304 & 10,00 & 4.598 .100 & 14,10 & -1.294 .796 \\
Goiás & 3.136 .230 & 9,49 & 2.086 .200 & 6,40 & 1.050 .030 \\
Paraná & 8.594 .000 & 26,01 & 5.574 .500 & 17,10 & 3.019 .500 \\
Rio Grande do Sul & 4.744 .064 & 14,36 & 4.964 .200 & 15,23 & -220.136 \\
Minas Gerais & 3.810 .304 & 11,53 & 3.913 .100 & 12,00 & -102.796 \\
outros & 6.449 .368 & 19,12 & 5.218 .100 & 16,01 & 1.096 .201 \\
& & & & & \\
total & 33.173 .500 & 100,00 & 32.600 .000 & 100,00 & 438.433 \\
\hline
\end{tabular}

Fontes: IBGE/CEPAGRO e CONAB 


\subsubsection{O setor da agroindústria}

Neste item abordam-se os três principais consumidores de milho: as indústrias moageiras via seca e via úmida e a indústria de rações para aves, suínos e, em menor escala, bovinos.

a) A indústria de moagem seca

$\mathrm{Na}$ moagem a seco, processo mais comumente utilizado, os produtos principais são a canjica e moídos, que respondem, em média, por cerca de $70 \%$ da produção, o farelo, com cerca de $20 \%$ e o óleo, representando $3 \%$. Os mais importantes derivados do milho destinados para o consumo humano, presentes no mercado nacional, são: pré-cozidos, flocados, farinhas, canjiquinhas e fubás, além dos produtos instantâneos, que se destinam à indústria alimentícia de massas, de panificação e uso doméstico; o gritz, para as indústrias cervejeiras, de snacks e de cereais matinais e, finalmente o óleo de milho. Atualmente já existe tecnologia para a produção de farinha de milho integral desengordurada, com características adequadas à panificação. Segundo a Associação Brasileira dos Moageiros o consumo industrial do milho na moagem a seco é representado conforme a figura 5.

Este tipo de indústria está espalhado por todas as regiões brasileiras, representada por um grande número de empresas de pequeno porte concentradas junto ao consumidor, sendo que o mais importante polo de transformação de milho localiza-se nos estados de São Paulo e Paraná. Dados da Associação Brasileira das Indústrias de Milho - ABIMILHO, porém, afirmam existir um razoável nível de concentração entre as maiores empresas. Segundo esta associação o volume produzido pelas seis maiores indústrias (C6) responde por cerca de $50 \%$ do total produzido no país. 
b) $A$ indústria de moagem úmida

$\mathrm{Na}$ moagem úmida os derivados principais são o amido e seus subprodutos. O amido é o produto mais importante, seja para uso direto ou como matéria-prima para um número muito grande de outros derivados.

Na produção de amido, o glúten (material protéico), o germe, o farelo e a água de maceração são subprodutos de alto valor comercial. O germe ou embrião é usado nas fábricas de óleo, a água de maceração ou água de milho é usada nas indústrias de fermentação, o glúten e o farelo na preparação de rações, principalmente. Os produtos derivados do milho no processo úmido e suas utilizações podem ser observados na figura 6 .

\begin{tabular}{|l|r|}
\hline Destino & \multicolumn{1}{|c|}{ (\%) } \\
\hline Cervejaria & 9,5 \\
Salgadinhos & 5,7 \\
Mineração & 2,2 \\
Empacotados & 28,5 \\
Pré-cozidos & 20,3 \\
Canjicão & 2,2 \\
Corn Flakes & 1,4 \\
Massas e Biscoitos & 2,2 \\
Gérmen & 25,0 \\
Quebra & 3,0 \\
TOTAL & 100,0 \\
\hline
\end{tabular}

Fonte: Associação Brasileira dos Moageiros.

Figura 5. Consumo industrial do milho por linha (moagem a seco).

Este mercado apresenta-se bastante concentrado, sendo composto basicamente por apenas três empresas, a Refiñações de Milho Brasil, Cargill e National. A Refinações possui fábricas em Mogi Guaçu, SP, em Balsa Nova, PR e Cabo, PE; a Cargill em Uberlândia, MG e, finalmente, a National em Trombudo Central, SC. 


\begin{tabular}{|c|c|}
\hline Linhas de produtos & Principais aplicações \\
\hline Xaropes de glicose de milho & $\begin{array}{l}\text { Fabricação de balas duras, mastigáveis, } \\
\text { gomas de mascar, doces em pasta, } \\
\text { sorvetes, frutas em calda e cristalizadas, } \\
\text { cames processadas, produtos } \\
\text { farmacêuticos e polimento de arroz. }\end{array}$ \\
\hline $\begin{array}{l}\text { Xaropes de glicose de milho com alto teor } \\
\text { de maltose }\end{array}$ & Fabricação de cervejas. \\
\hline Corante caramelo & $\begin{array}{l}\text { Fabricação de refrigerantes, cervejas, } \\
\text { bebidas alcoólicas e molhos. }\end{array}$ \\
\hline Malto dextrinas & $\begin{array}{l}\text { Fabricação de aromas e essências, } \\
\text { sopas desidratadas, pós para sorvetes, } \\
\text { complexos vitamínicos e produtos } \\
\text { achocolatados. }\end{array}$ \\
\hline Amido de milho regular alimentício & $\begin{array}{l}\text { Fabricação de biscoitos, melhoradores } \\
\text { de farinha, pães, pós para pudins, } \\
\text { fermento em pó, macarrão e produtos } \\
\text { farmacêuticos. }\end{array}$ \\
\hline Amido de milho regular industrial & $\begin{array}{l}\text { Fabricação de papel, papelão ondulado, } \\
\text { adesivos, briquetes de carvão, } \\
\text { engomagem de tecidos e beneficiamento } \\
\text { de minérios. }\end{array}$ \\
\hline Amidos modificados alimentícios & Fabricação de balas e gomas. \\
\hline Amidos modificados & $\begin{array}{l}\text { Fabricação de papel, papelão ondulado, } \\
\text { fitas gomadas e engomagem de fios } \\
\text { têxteis. }\end{array}$ \\
\hline Dextrinas de milho & $\begin{array}{l}\text { Fabricação de adesivos, tubos e tubetes, } \\
\text { barricas de fibra, lixas, abrasivos, sacos } \\
\text { de papel multifolhados, estampagem de } \\
\text { tecidos, cartonagem e beneficiamento de } \\
\text { minérios. }\end{array}$ \\
\hline Adesivos vegetais & $\begin{array}{l}\text { Fabricação de sacos, tubos e tubetes, } \\
\text { fechamento de caixas de papelão, } \\
\text { rotulagem de garrafas, rotulagem de } \\
\text { latas, colagens em papel, madeira e } \\
\text { tecidos. }\end{array}$ \\
\hline Ingredientes protéicos para ração animal & $\begin{array}{l}\text { Formulações de rações balanceadas } \\
\text { para bovinos, aves, suínos e cães. }\end{array}$ \\
\hline
\end{tabular}

Fonte: Refinações de milho Brasil S.A.

Figura 6. Produtos derivados do milho e suas aplicações (moagem úmida). 
A partir de informações obtidas junto a empresas do setor pode-se estimar o elevado índice de concentração de Hirschman-Herfindahl $(H)$ que, em 1994 foi de 0,61243. Este alto nível de concentração se dá em função dos altos níveis de investimentos necessários para sua instalação.

c) A indústria de rações.

O milho juntamente com 0 farelo de soja constitui-se no principal componente das rações para animais. Segundo informações do Sindicato Nacional da Indústria de Rações Balanceadas - SINDIRAÇÕE,S, enquanto a soja participa com cerca de $15 \%$ em média na sua formulação, o milho participa com cerca de $68 \%$ na formulação de rações para avicultura de corte, $60 \%$ para postura de ovos, $46 \%$ para bovinos e até $70 \%$, no caso de ração para suínos. A indústria de rações apresenta uma linha de produtos superior a 50 itens, subdivididos em rações e concentrados e que se destinam quase que totalmente às atividades acima citadas que podem se subdividir ainda em diversos produtos em função do sexo do animal, da fase de crescimento e da finalidade a que ele se destina. Ainda segundo esta fonte, a avicultura no ano de 1993 consumiu $66,4 \%$ da ração produzida no país (46,7 para a atividade de corte e $19,7 \%$ para a postura), seguida pela suinocultura com $24,9 \%$, bovinocultura com $5,4 \%$ e o restante (cães, ovinos, caprinos, eqüinos etc.) com cerca de 3,5\%. Quanto à evolução desta demanda pode-se observar pela tabela 10 que entre 1988 e 1993 houve significativo crescimento da ordem de $6,67 \%$ a.a. gerando grande impacto na demanda de milho já que esta destinação representa de 40 a $50 \%$ do total de milho consumido no país, dependendo da fonte consultada (tabelas 5 e 6 ). 
Tabela 10 - Estimativa da demanda de rações balanceadas no Brasil, em mil t (1988-93).

\begin{tabular}{lrrrrrrr}
\hline tipos & \multicolumn{1}{c}{1988} & \multicolumn{1}{c}{1989} & 1990 & \multicolumn{1}{c}{1991} & 1992 & 1993 & $\begin{array}{r}\text { cresc. } \\
\text { a.a. (\%) }\end{array}$ \\
\hline corte & $6.176,0$ & $6.520,7$ & $7.491,7$ & $8.035,9$ & $8.614,2$ & $8.917,5$ & 7,83 \\
postura & $3.007,9$ & $2.753,8$ & $2.989,5$ & $3.286,6$ & $3.733,1$ & $3.776,8$ & 6,13 \\
bovinos & 921,5 & 830,0 & 853,6 & 812,2 & 790,7 & $1.039,7$ & 1,17 \\
suinos & $3.778,9$ & $3.631,2$ & $3.865,2$ & $4.526,7$ & $4.598,1$ & $4.773,7$ & 5,81 \\
outros (1) & 330,0 & 436,6 & 423,8 & 519,9 & 517,2 & 604,9 & - \\
total & $14.214,3$ & $14.172,3$ & $15.623,8$ & $17.181,3$ & $18.253,3$ & $19.112,6$ & 6,67 \\
\hline
\end{tabular}

(1) rações para cães, ovinos, caprinos, suínos, eqüinos etc.

Fonte: Sindirações.

Quanto à distribuição geográfica, constata-se que a produção de rações se concentra basicamente nos Estados do Sul e Sudeste, respondendo por cerca de $92,6 \%$ do total produzido no país pelas empresas associadas à SINDIRAÇÕES. Santa Catarina é o maior estado produtor seguido por São Paulo, Paraná, Minas Gerais e Rio Grande do Sul, com grande parte desta produção sendo consumida no próprio estado de origem, conforme tabela 11.

Ainda segundo esta fonte, percebe-se um alto nivel de concentração das empresas nestas regiões, na medida em que se considerarmos apenas as unidades fabris que produzem volumes acima de 12.000 t/ano, elas respondem por cerca de $72 \%$ da produção de rações para aves de corte na região Sul e a $40 \%$ na Sudeste.

Cabe ressaltar que parcela da produção da indústria de rações está sendo efetuada pelos próprios frigoríficos, que adquirem os microingredientes desta indústria e os misturam ao demais elementos adquiridos diretamente dos produtores rurais, comerciantes, ou através de importações, em muitos casos através de draw-back (SOUZA \& SANSON, 1993).

Entre 1986/1988, o volume de rações produzidos pelos frigoríficos avicolas excedeu a quantidade produzida pelas indústrias de rações. Em 
1988, os frigoríficos produziram 7,3 milhões de toneladas de rações, enquanto a produção total do País foi de 14,2 milhões (MALHEIROS, 1991).

Tabela 11 - Total de produção e consumo de rações por Estado (safra 1993).

\begin{tabular}{lrrrrrr}
\hline Estados & \multicolumn{2}{c}{ produção } & \multicolumn{2}{c}{ consumo $(1)$} & \multicolumn{2}{c}{ saldo } \\
& \multicolumn{1}{c}{$t$} & $(\%)$ & \multicolumn{1}{c}{$t$} & \multicolumn{1}{c}{$(\%)$} & \multicolumn{1}{c}{} & \multicolumn{1}{c}{$(\%)$} \\
\hline São Paulo & 1.553 .910 & 23,68 & 1.397 .949 & 21,31 & 155.961 & 10,04 \\
Santa Catarina & 2.214 .222 & 33,75 & 2.247 .889 & 34,26 & -33.667 & $-1,52$ \\
Paraná & 1.125 .269 & 17,15 & 1.100 .455 & 16,77 & 24.814 & 2,21 \\
Minas Gerais & 542.978 & 8,28 & 571.313 & 8,71 & -28.335 & $-5,22$ \\
Rio Grande do Sul & 541.895 & 8,26 & 535.913 & 8,17 & 5.982 & 1,10 \\
Rio de Janeiro & 92.803 & 1,41 & 134.723 & 2,05 & -41.920 & $-45,17$ \\
outros & 490.452 & 7,47 & 573.287 & 8,73 & -82.835 & $-16,89$ \\
& & & & & & \\
total & 6.561 .529 & 100,00 & 6.561 .529 & 100,00 & 0 & 0 \\
\hline
\end{tabular}

(1) Empresas filiadas ao Sindirações

Fonte: Sindirações.

Segundo MARQUES (1991) tem havido uma tendência de aumento na concentração das firmas com menores participações no mercado. De fato, FERRARI (1996) observa que o setor avícola apresenta uma produção relativamente concentrada em poucas empresas, sendo que as cinco maiores empresas de frango responderam, em 1995, por mais de $36 \%$ do mercado consumidor. Em 1980, esta participação não passava de 17\%.

As maiores empresas brasileiras do setor de beneficiamento de carnes são: Sadia, Perdigão, Ceval, Frangosul, Avipal (NUNES, 1.993)

\subsection{Relações contratuais}

As diversas cadeias agroindustriais de alimentos que compõem $\circ$ denominado agribusiness estão organizadas e distribuídas em atividades específicas, onde as unidades produtivas rurais e indústria à sua montante se 
inter-relacionam, na maioria das vezes, através de contratos formais e informais que não incluem a venda direta ao mercado (FARINA $\varepsilon$ ZILBERSZTAJN, 1993).

Segundo MARION (1976), citado por SOUZA et al. (1994), as razões que levam a simples contratação do mercado até a integração para a coordenação do fluxo do produto na cadeia agroindustrial alimentar podem ser identificadas tanto pelo produtor rural quanto pela agroindústria como as seguintes: aumentar a eficácia, ganhar vantagem de mercado e reduzir custos ou obter financiamento. Para decidir entre a simples contratação do mercado, a quase integração ou a integração vertical os agentes da cadeia estão atentos às falhas de mercado, à interdependência tecnológica e à estrutura de mercado nos seus aspectos de competitividade. Portanto, é preciso ressaltar que existe um conjunto de alternativas entre estes extremos contratuais, em que as firmas em estágios sucessivos no processo de produção estão ligadas e onde as operações são coordenadas, embora as unidades produtivas permaneçam como propriedades independentes. Estes casos intermediários invariavelmente envolvem contratos especializados e são conhecidos por termos como quase integração ou contratos "comerciais não padronizados de mercado", como nos casos das agroindústrias da laranja e da soja (WILLIAMSON, 1985). THAME \& AMARO (1987) apresentam razões que levam as agroindústrias e os produtores rurais à adoção desses contratos:

- Para a agroindústria: a) Conquista de posição no mercado - as indústrias preferem fornecedores fixos pois facilita o suprimento de matériaprima; b) Redução de custos - o suprimento contínuo permite manter uma economia de escala; c) As necessidades das empresas processadoras oferecerem produtos na quantidade e qualidade requeridas pela demanda; $d$ ) O compromisso da empresa com um número menor de agricultores de maior escala, de forma a se reduzir o custo da coleta de matéria-prima. 
- Para o produtor: a) Facilidade de aumentar a produção a partir da introdução de tecnologia; b) Orientação técnica; c) Redução dos riscos de preços pois o mercado está assegurado; e d) Menos incertezas em aplicar e adquirir insumos.

KHOLS et al. (1985) distinguem três tipos de contratos:

- contratos de especificação de mercado, onde se define apenas o produto e a forma de pagamento e o manejo e a administração são de responsabilidade do produtor.

- contrato de provisão de recursos, que especifica os insumos a usar e o local de compra, com a processadora financiando, auxiliando e supervisionando a administração da produção. Trata-se da quase-integração, aproximando-se do tipo de contrato das cadeias da laranja e da soja.

- contrato de administração e garantia de renda, que combina as características dos dois contratos anteriores e ainda considera a transferência de riscos de preços do produtor para o contratante. Trata-se do contrato de parceria ou da integração vertical. O exemplo mais bem sucedido de integração vertical no agribusiness brasileiro é a cadeia da avicultura de corte. Marques (1991) estudou a economia da integração vertical na agricultura de corte no Estado de São Paulo e concluiu, entre outras coisas, que as empresas e os produtores realizam diversas formas de contratos onde a integradora fornece insumos e assistência técnica, enquanto 0 integrado deve se encarregar da produção e, na maioria das vezes, ser obrigado a vender o produto para a empresa. Desta forma o produtor seria um fornecedor de mãode-obra e infra-estrutura, tendo pouca ou nenhuma atuação nas decisões técnico-administrativas. A remuneração do produtor é feita com base no índice de desempenho da sua atividade produtiva. Ainda segundo Marques, os frigoríficos paulistas começaram lentamente a se integrar à partir de 1969; o processo ganhou impulso a partir de 1981 e em 1991, cerca de $71 \%$ da produção paulista já estava integrada. 
No tocante às relações contratuais na cadeia agroindustrial do milho envolvendo produtores e processadoras, excetuando-se algumas empresas isoladas que praticam a troca de sementes por produto, de um modo geral, não se observa nenhum destes tipos de contratos. Diferentemente da soja, a quase totalidade das fontes de recursos para o financiamento da produção daquele cereal continua sendo o governo, através de linhas de crédito de custeio e, posteriormente, de comercialização. As operações conhecidas por escambo ou troca-troca" largamente difundidas entre produtores e compradores de soja, não tem despertado interesse aos agentes da cadeia do milho. Neste caso, o produtor assume o compromisso de entregar parte de sua produção na época da colheita em troca do recebimento de insumos (como adubo, inseticidas, herbicidas etc.), que viabilizarão o seu plantio. Este tipo de operação tem diferentes vantagens para ambas as partes envolvidas:

- para o produtor representa uma importante opção de crédito na medida em que a disponibilidade de recursos formais torna-se cada vez mais escassa, ao mesmo tempo que indexa a sua dívida ao seu produto, evitando riscos de distorções que podem ocorrer em função de eventuais mudanças das políticas econômicas, como as que tem ocorrido com freqüência nos últimos anos.

- para a agroindústria permite uma programação antecipada, gerando ưma melhor distribuição nas vendas e/ou um melhor planejamento da produção industrial e logística.

Basicamente o que viabilizou este tipo de contrato na soja foi a existência do mecanismo de hedge praticado na Bolsa de Mercados Futuros de Chicago e, mais recentemente, com a possibilidade de se fazer no Brasil com a implantação deste mercado na Bolsa de Mercadorias e Futuros (BM\&F), que asseguram margens de preços razoáveis às indústrias e exportadoras. A proteção obtida nestas operações permite que estas empresas adiantem recursos para compras antecipadas de mercadorias que somente serão entregues vários meses depois, mercadorias estas sujeitas a forte sazonalidade e, portanto a grandes oscilações de preços. Este benefício, no 
entanto, não se enquadra para operações envolvendo milho, pois apesar da grande liquidez deste produto na Bolsa de Chicago, ela tornar-se-ia sem efeito em termos de proteção aos compradores, em função da falta de paridade entre os preços domésticos e internacionais do milho. Assim, a existência de um contrato futuro forte deste cereal no Brasil poderia viabilizar esta operação. Discussão mais aprofundada sobre esta operação será realizada no capitulo 3 .

Outras formas de contratos entre produtores e agroindústrias são os recém-criados títulos representativos de mercadorias como o CM-G (Certificado de Mercadoria com Emissão Garantida) e CPR (Cédula de Produto Rural). Apesar de recentes, estes títulos começam a ter aceitação no mercado já que representam benefícios tanto aos produtores, como forma alternativa de financiamento de sua safra, quanto às agroindústrias, proporcionando um melhor planejamento em seu fluxo de recebimento de matéria-prima e da garantia de recebimento do produto geralmente através de fiança bancária. $O$ governo tem também benefícios indiretos com o incremento de sua utilização já que o liberaria para um melhor direcionamento dos escassos recursos de crédito oficial para custeio de safras agrícolas, priorizando os setores com menos alternativas de fontes de recursos, tais como as culturas de subsistência, agricultores de pequeno porte e regiões mais carentes.

Algumas limitações ainda existentes para o pleno desenvolvimento deste mecanismo estariam relacionadas à falta de seguros agrícolas eficientes para a produção e os riscos referentes às oscilações de preços assumidos pelos compradores destes títulos ao final da safra. Segundo FRICK (1995) o credor, ao comprar uma CPR, está alocando recursos para dispor de uma commodity no vencimento do título. Trata-se, então, de uma aplicação indexada por commodity - muitas vezes cotadas em dólar - que tem embutida uma determinada taxa de juro e uma certa taxa de câmbio. Assim, os riscos associados à sua posição são os de ter recursos mal aplicados devido à queda de preço do produto, ao aumento da taxa de juro elou à queda da taxa de câmbio em produtos de exportação. De forma análoga, o emitente da CPR, o 
produtor rural, correrá os riscos inversos, ou seja, aumento de preço da commodity negociada, queda da taxa de juros e/ou elevação da taxa de câmbio, quando a CPR se referir a um produto de exportação.

Estratégias envolvendo a utilização de mercados futuros e títulos representativos de mercadorias permitiriam uma melhor administração de risco de preço para compradores e melhoria nas condições de financiamento para vendedores. Assim, além de garantir melhores margens para as agroindústrias e traders, os mercados futuros poderiam oferecer aos produtores importante referencial de preços futuros, auxiliando na sua negociação. Na tabela 12 pode-se observar os volumes de contratos negociados de CPR até janeiro de 1996. No ano de 1994, foram realizadas experiências com diversos produtos, entre os quais o milho e no ano seguinte foram lançadas oficialmente, pelo Banco do Brasil, as cédulas de soja e café. Segundo a Divisão de CPR da Diretoria de Crédito Rural desta instituição, responsável pelos estudos e divulgação de normas de novos produtos, a opção por estes dois produtos deveu-se basicamente à existência de um Mercado Futuro destas commodities, o que possibilitaria os benefícios acima discutidos.

Tabela 12 - Número de contratos e volumes físicos e financeiros de Cédulas de Produto Rural - CPR, por commodity (até janeiro/96).

\begin{tabular}{lccr}
\hline produto & $\mathrm{n}^{0}$ contratos & volume $(\mathrm{t})$ & \multicolumn{1}{c}{$\mathrm{R} \$$} \\
\hline milho & 10 & 4.929 & $376.580,00$ \\
soja & 598 & 398.352 & $62.309 .613,10$ \\
café & 45 & 1.968 & $3.043 .195,60$ \\
\hline
\end{tabular}

Fonte: DIRUR/DEAPE/BB-CPR 


\subsection{Comportamento e formação dos preços}

\subsubsection{Comportamento dos preços}

O milho, como a quase totalidade dos produtos agrícolas, está sujeito a variações de preços ao longo dos anos assim como durante o próprio ano. Estas flutuações nos preços dos produtos agrícolas podem ser desdobradas em três fatores: tendência, ciclo e sazonalidade.

A tendência pode ser observada dispondo-se de uma série histórica de preços, permitindo-se observar se existe uma tendência de queda, alta ou estabilização de preços. Não havendo grandes mudanças nos fatores que agem sobre um determinado mercado, seria de se esperar que os preços mantivessem a tendência indicada pela série história. Alterações na tendência estariam basicamente ligadas a inovações tecnológicas, mudanças de hábitos, diferentes taxas de crescimento entre oferta e demanda etc.

Os ciclos referem-se a flutuações que ocorrem em períodos maiores que um ano, geralmente associadas ao comportamento do produtor diante do mercado e ao ciclo produtivo de seu produto. Cita-se, como exemplo, o mercado do boi gordo, com ciclos de 6-7 anos.

Finalmente, tem-se a sazonalidade, caracterizada por um movimento de preços ao longo do ano devido à safra e entressafra, estações do ano, hábitos dos consumidores etc. Como conseqüência da sazonalidade, 0 produtor receberá preços menores durante a safra e mais atraentes ao longo da entressafra. A figura 7 mostra que, para o milho no Estado de São Paulo, a safra é ao redor de abril e a entressafra, ao redor de dezembro, conforme constataram SOUSA \& MARQUES (1994) e COUTO \& HACKENHAAR (1994). Cabe ressaltar a existência de um segundo vale" de preços em junho, em menor escala, que coincide com a entrada da chamada safrinha, prática cada vez mais utilizada por agricultores como forma de otimizar a utilização da terra. 
Pode-se, também detectar, através de dados dos últimos 24 anos, duas tendências bastante importantes. A primeira diz respeito à diminuição dos preços recebidos pelos produtores ao longo destes anos, o que pode ser explicado basicamente em função do aumento de produtividade e da queda dos preços internacionais desta commodity, pressionando os preços internos para baixo, conforme mostrado no figura 8 . A segunda observação importante refere-se à mudança do padrão do comportamento sazonal dos preços, ao longo do período analisado, com os "vales" de preços (meses de safra) se antecipando, conforme o mesmo gráfico, provavelmente em função do aumento da utilização de variedades de milho precoce e de colheitadeiras automotrizes. Estes resultados foram obtidos através da utilização do método de Análise de Regressão Linear Múltipla com utilização de variáveis binárias. Assim, foram obtidas estimativas dos parâmetros, mostrando de forma direta a variação estacional dos preços em três sub-períodos distintos, 1970/79, 1980/89 e 1990/94 (SOUSA, 1994).

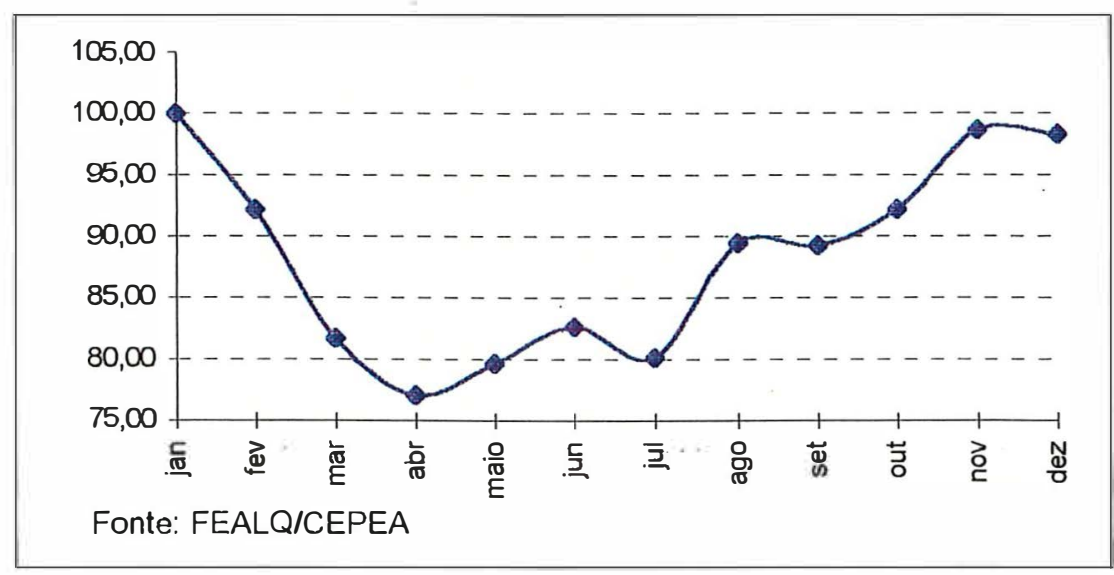

Figura 7. Índice de preços médios mensais de milho no Estado de São Paulo (1987-96) deflacionados pelo IGP-DI/FGV. 


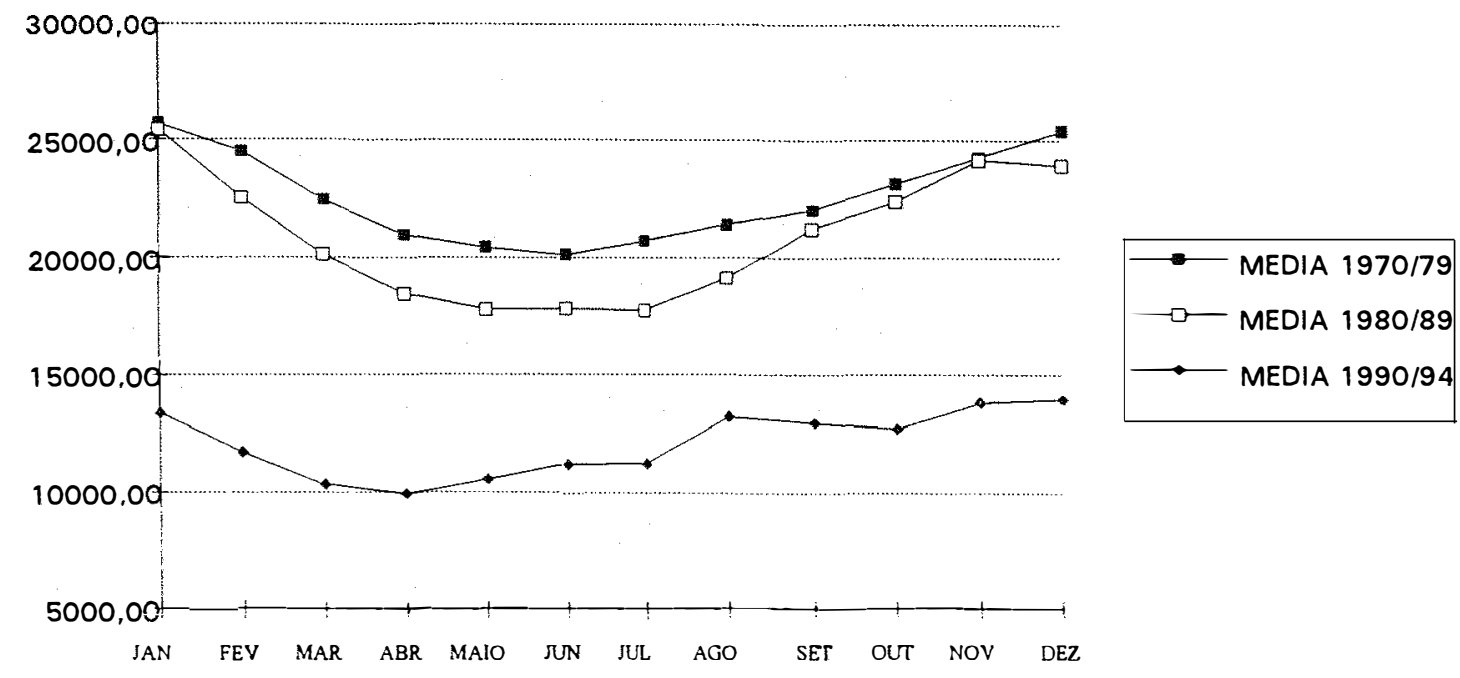

Fonte: Instituto de Economia Agrícola -IEA

Figura 8. Preços médios mensais de milho no Estado de São Paulo, em Cr\$/sc de $60 \mathrm{~kg}$ - base maio/94 (deflacionados pelo IGP-DI/FGV).

Utilizando índices calculados a partir de dos preços médios mensais de alguns dos principais produtos agropecuários (milho, soja, boi gordo, cana-deaçúcar, algodão, café beneficiado e feijão) entre os anos de 1987 e 1996, pode-se comparar sua estacionalidade e observar que 0 milho é 0 que apresenta o segundo maior desvio padrão e amplitude, ficando atrás apenas do feijão (Tabela 13, elaborada a partir de dados do apêndice 4). Conclusão semelhante foi efetuada por BERALDO (1993) que, a partir de estudos sobre a variação estacional de preços de produtos agrícolas (algodão, arroz, feijão, milho e soja), avaliou sua amplitude e a dispersão e verificou que o milho foi a commodity agrícola com maior dispersão e amplitude médias entre as cinco principais culturas no periodo referente aos anos de 1982/90. Em 1991 manteve-se alta ficando porém abaixo do feijão e do arroz que apresentaram 
elevação expressiva em seus índices neste ano e, em 1992 volta a apresentar o maior desvio padrão, ficando com amplitude abaixo apenas do feijão.

Tabela 13 - Índices de variação estacional de preços dos principais produtos agropecuários (1987-96).

\begin{tabular}{lrrrrrrr}
\hline mês & \multicolumn{1}{c}{ milho } & \multicolumn{1}{c}{ soja } & \multicolumn{1}{c}{ boi } & \multicolumn{1}{c}{ cana } & algodão & \multicolumn{1}{c}{ café } & \multicolumn{1}{c}{ feijão } \\
\hline jan & 100,00 & 100,00 & 100,00 & 100,00 & 100,00 & 100,00 & 100,00 \\
fev & 91,38 & 96,46 & 92,95 & 104,37 & 111,59 & 94,96 & 105,68 \\
mar & 81,00 & 89,53 & 89,69 & 101,08 & 106,80 & 95,07 & 125,81 \\
abr & 76,40 & 85,10 & 90,75 & 96,77 & 105,13 & 92,77 & 132,82 \\
maio & 79,00 & 87,65 & 90,16 & 101,20 & 102,45 & 96,81 & 139,42 \\
jun & 81,92 & 90,36 & 90,10 & 99,56 & 96,66 & 91,67 & 136,18 \\
jul & 79,41 & 90,78 & 93,25 & 96,90 & 91,30 & 88,05 & 119,23 \\
ago & 88,70 & 92,34 & 104,05 & 97,91 & 92,31 & 86,15 & 105,27 \\
set & 88,54 & 93,64 & 102,53 & 99,18 & 98,44 & 88,49 & 97,55 \\
out & 91,38 & 94,48 & 100,47 & 99,18 & 101,11 & 84,53 & 107,82 \\
nov & 97,82 & 95,47 & 99,74 & 98,54 & 103,01 & 82,60 & 111,56 \\
dez & 97,49 & 98,33 & 90,10 & 99,11 & 94,65 & 79,78 & 97,10 \\
& & & & & & & \\
desvpad & 8,14 & 4,40 & 5,56 & 2,07 & 6,03 & 6,16 & 15,35 \\
amplitude & 23,60 & 14,90 & 14,36 & 7,59 & 20,29 & 20,22 & 42,32 \\
\hline Fon
\end{tabular}

Fonte: Dados originais da FEALQ/CEPEA

\subsubsection{Formação dos preços}

Alguns fatores relevantes na formação e determinação de preços de milho no Brasil atualmente são:

- Política de preços mínimos e disponibilidade de recursos oficiais de comercialização (principalmente Aquisição pelo Governo Federal - AGF e Empréstimo do Governo Federal com opção de venda - EGF-COV), na medida em que havendo interferência do governo ao adquirir o produto pelo preço mínimo, este servirá como piso para as negociações do produto; 
- Produção, estoques privados e públicos e demanda nacional, principalmente do setor de aves e suínos;

- Preço de paridade do produto importado nas regiões consumidoras, na medida que este servirá como teto para as negociações;

- Custos financeiros e de armazenamento;

- Oferta dos principais grãos substitutos, principalmente os utilizados com insumos de rações animais;

- Impacto da abertura econômica e formação de blocos econômicos internacionais como o Mercosul;

- À longo prazo, mudanças nos hábitos de consumo e dos métodos de produção de milho e de produtos finais que utilizem o grão como insumo na sua fabricação.

\subsection{Competitividade.}

O Brasil é o terceiro maior produtor de milho ficando atrás dos EUA e China cujas produções responderam por $41,5,19,7$ e 5,8\% da produção mundial quando considerada a média no período entre 1991 e 1995 (tabela 2). Apesar disto, sua produtividade média ainda fica muito abaixo da maioria dos principais países produtores; considerando-se o mesmo período, sua produtividade média correspondeu a cerca de $30 \%$ da produtividade americana, $46 \%$ da chinesa, $52 \%$ da argentina e apenas $56 \%$ da produtividade média mundial.

Quanto ao comércio exterior, o Brasil caracteriza-se por ser um país importador de milho, não registrando exportações desde a safra 1984/85 (tabela 8) e o último ano em que este produto foi item significativo da pauta de exportações do Brasil foi 1970, quando atingiu $3 \%$ do valor das exportações do país (SOUZA \& SANSON, 1993, p. 42). As importações são regionalizadas, nas regiões Sul e Nordeste, e ocorrem principalmente nos periodos de 
entressafra. A demanda da região Nordeste pelo milho importado estaria associada à falta de competitividade do produto oriundo do Centro-Sul basicamente em função dos elevados custos de fretes terrestres somados aos impostos a que está sujeito. SANTO et al. (1994), destacam a auto-suficiência da região Sudeste observando que o porto de Santos recebeu apenas $0,12 \%$ do milho importado da Argentina no ano de 1993, enquanto a importação proveniente dos Estados Unidos alcançou apenas 1,7\% do total do país. Considerando o período entre 1985 e março de 1994 pode-se observar na tabela 14 que a Argentina responde pela maior parte das importações brasileiras do produto $(58,84 \%$, na média), seguida dos EUA representando $36,68 \%$ do total, no período.

Tabela 14 - Importações brasileiras de milho por país de origem, em $1.000 \mathrm{t}$ (entre 1985-94).

País $\quad 1985198619871988198919901991199219931994$ média

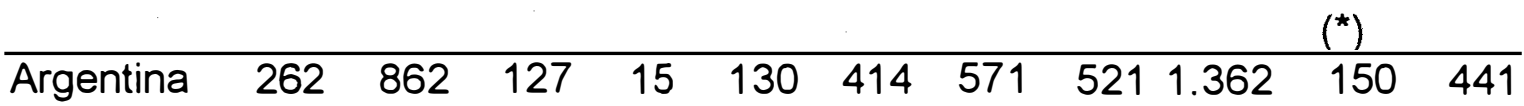

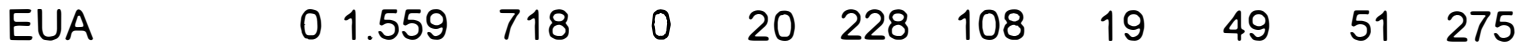

$\begin{array}{llllllllllll}\text { Outros } & 0 & 3 & 26 & 0 & 6 & 55 & 127 & 6 & 78 & 34 & 34\end{array}$

$\begin{array}{llllllllllll}\text { Total } & 262 & 2.424 & 871 & 15 & 156 & 696 & 806 & 547 & 1.489 & 235 & 750\end{array}$

$\left(^{*}\right)$ até março

Fonte: FNP Consultoria \& Comércio/Decex - BB

A figura 9 mostra a comparação dos preços médios mensais do milho brasileiro com os dos EUA e Argentina, principais exportadores do produto. Observa-se que os preços do milho brasileiro, com exceção do período dos meses de março e abril, situam-se sempre acima dos praticados na Argentina e EUA. Naqueles meses os preços ficam abaixo dos preços nos EUA em função da colheita do produto no Brasil. Os "vales" de preços na Argentina e Brasil ocorrem no início do ano, coincidindo com a safra nestes países. Nos EUA, por 
outro lado, a safra ocorre a partir de meados do segundo semestre, razão pela qual, neste período, há uma depressão nos preços médios neste país. Observa-se, também, que a alta na Argentina é menos acentuada do que no Brasil já que aquele país caracteriza-se como sendo exportador de milho (cerca de $50 \%$ de sua produção) e, portanto, mais sujeito à influência dos preços internacionais principalmente dos EUA, maior exportador mundial.

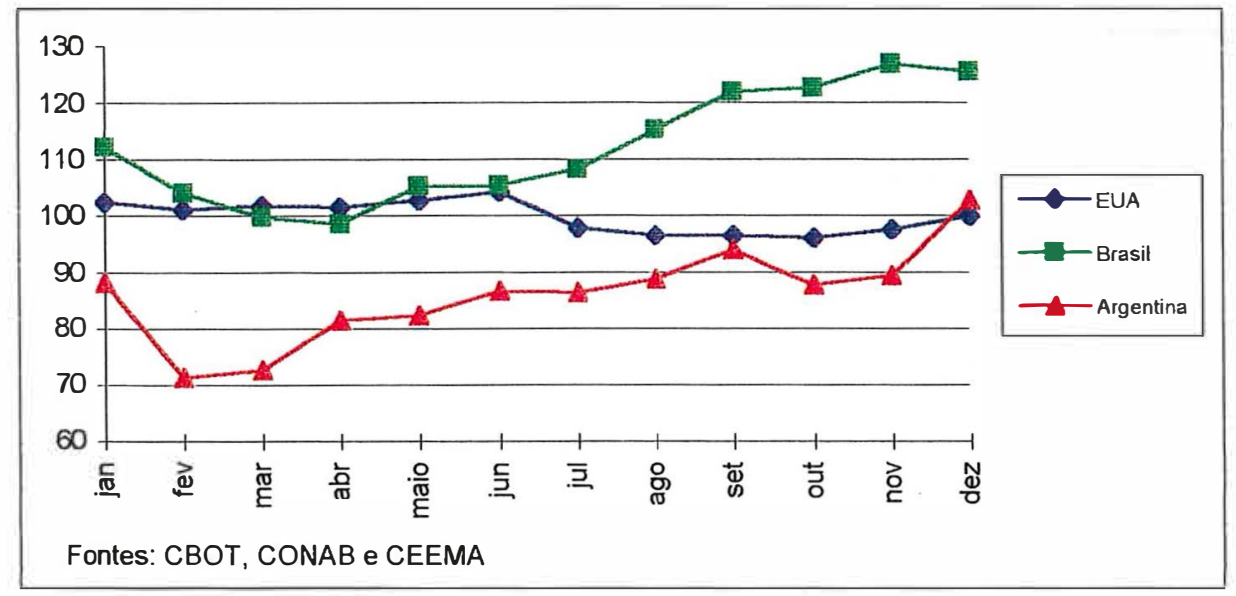

Figura 9. Preços médios mensais do milho no Brasil, EUA e Argentina entre 1989 e1995 (US\$ /t - valores nominais) .

ORTMANN, RASK e STÜLP (1989) compararam os custos de produção e comercialização do milho entre Brasil, Argentina e EUA. O termo de comparação final foi o custo dos produtos colocados em Roterdã e no Japão. O custo FOB (Tabela 15) refere-se ao custo do produto colocado no navio, no porto de exportação; ele inclui o custo de produção (excluída a remuneração da terra) e o de comercialização (transporte, carregamento, taxas portuárias etc.). A renda da terra, no agregado, é uma função do preço do produto, estando sujeita à política de subsídios, impostos etc, refletindo, portanto, as diferenças de política econômica entre países. Contudo quando a renda da terra foi incluída no cálculo dos custos FOB a ordem dos países não foi alterada 
significativamente (ORTMANN, RASK e STÜLP, 1989, p.11). Pode perceber a falta de competitividade brasileira tanto a nivel de custo interno como quando se compara o produto colocado nos países consumidores.

Tabela 15 - Custos de milho no porto (FOB), em Roterdã e no Japão (US\$/t)

\begin{tabular}{lccc}
\hline País & custo FOB & Roterdã & Japão \\
\hline Brasil & 151,00 & 168,00 & 185,00 \\
Argentina & 102,00 & 121,00 & 134,00 \\
EUA & 122,00 & 135,00 & 148,00 \\
\hline
\end{tabular}

Fonte: ORTMANN, RASK e STÜLP (1989).

A tabela 16 mostra os custos médios por tonelada dos produtores de milho no Brasil, Argentina, e EUA. Nota-se que os custos brasileiros são mais elevados que os dos demais países. Analisando-se os custos variáveis percebe-se que um dos fatores que mais influencia nesta diferença diz respeito à utilização de fertilizantes; custo nulo no caso argentino e cerca de $40 \%$ do custo brasileiro no caso dos EUA, em função da menor fertilidade média dos solos brasileiros e do elevado preço do insumo. Outro aspecto a se considerar é que o produtor argentino contrata as máquinas para a execução de várias tarefas. Em algumas regiōes executa as tarefas de preparo de solo e plantio com maquinaria própria, mas contrata máquinas para as demais tarefas, principalmente a colheita. Assim, verifica-se que, ao comparar os custos de combustiveis (incluídos em "butros" no caso argentino), de operação com máquinas e de reparos, bem como mão de obra volante, o produtor argentino leva vantagem sobre o brasileiro, que usa maquinaria e pessoal próprios, incorrendo em maiores custos, no entanto, quanto à contratação de máquinas. Da mesma forma, o Brasil é também mais penalizado frente aos outros dois paises quando se compara as despesas financeiras, impostos diretos e indiretos e seguros onerosos e geralmente ineficientes, no caso brasileiro. VILLWOCK (1993) afirma que a falta de competitividade do milho brasileiro 
frente aos paises do Mercosul estaria fortemente relacionada com a baixa produtividade média no Brasil e que produtividades abaixo de $3.000 \mathrm{~kg} / \mathrm{ha}$ nos Estados da região Sul inviabilizaria a atividade no longo prazo.

Tabela 16 - Custos de produção de milho na Argentina, Brasil e EUA (em US\$/t).

\begin{tabular}{|c|c|c|c|}
\hline $\begin{array}{l}\text { País } \\
\text { localização }\end{array}$ & $\begin{array}{c}\text { Argentina } \\
\text { Buenos Aires }\end{array}$ & $\begin{array}{c}\text { Brasil } \\
\text { Centro-Sul }\end{array}$ & EUA \\
\hline 1) Custos variáveis & 56,50 & 82,33 & 48,88 \\
\hline sementes & 9,75 & 12,66 & 6,05 \\
\hline pesticidas & 5,25 & 2,50 & 6,44 \\
\hline fertilizantes & 0,00 & 29,00 & 11,84 \\
\hline mão de obra permanente & 7,75 & 2,00 & 2,12 \\
\hline mão de obra temporária & 0,25 & 3,83 & 6,86 \\
\hline operação com máquinas & & 29,34 & 11,71 \\
\hline reparo de máquinas & 0,50 & 3,00 & 3,75 \\
\hline contratação de máquinas & 25,75 & 0,00 & 0,00 \\
\hline outros gastos & 7,25 & 26.71 & 0,11 \\
\hline 2) Despesas financeiras & 10,25 & 16,17 & 9,10 \\
\hline juros & 3,00 & 6,67 & 4,04 \\
\hline impostos e seguros & 7,25 & 9,50 & 5,06 \\
\hline Sub-total $(1+2)$ & 66,75 & 98,50 & 57,97 \\
\hline 3) Custos econômicos & n.d. & 53,81 & 41,82 \\
\hline depreciação do capital & n.d. & 23,30 & 20,91 \\
\hline remuneração da terra & n.d. & 21,67 & 17,66 \\
\hline $\begin{array}{l}\text { remuneração sobre capital } \\
\text { fixo }\end{array}$ & n.d. & 8,84 & 3,26 \\
\hline Total $(1+2+3)$ & - & 152,31 & 99,79 \\
\hline
\end{tabular}

Fontes: STÜLP (1992), CONAB (1995) e USDA (1992)

As produtividades consideradas para Brasil e EUA foram, respectivamente, 3,0 t/ha e 9,0 t/ha. 
Analisando-se os efeitos da incidência de impostos e tarifas alfandegárias nos três países ao nivel de propriedade rural, pode-se constatar que o Brasil é o mais penalizado pelas políticas públicas. Este fato pode ser associado à baixa lucratividade da produção de milho no país, à incidência dos impostos "em cascata" (ICMS, COFINS, PIS, FUNRURAL, IPI etc.) e às altas tarifas de proteção de insumos produtivos, como máquinas, implementos e agroquímicos se comparadas com as argentinas que realizou uma maior e mais eqüitativa abertura econômica (JANK et al., 1994). Esta distorção fiscal, juntamente com a baixa produtividade, podem ser apontadas como as principais causas que inviabilizam as exportações do grão.

Com relação à integração agrícola do Brasil no Mercosul, alguns problemas importantes são levantados por JANK (1.994), como por exemplo:

- Harmonização das políticas econômicas, como estabilidade econômica, política tributária e política cambial;

- Fixação da tarifa comum;

- Harmonização da política comercial;

- Harmonização da política agrícola e

- Outras políticas públicas, como a reconversão produtiva ou a reorientação da produção em caso de perda de competitividade.

Assim, o autor sugere algumas providências que deveriam ser tomadas rapidamente para que esta integração seja efetivamente benéfica ao setor e à sociedade. Entre elas, cita: a) necessidade de se equiparar as tarifas entre os segmentos, eliminando qualquer discriminação contra o setor agropecuário pelas indústrias correlatas; b) harmonização da legislação anti-dumping e antisubsídios; c) harmonização da política tributária, sendo que a brasileira é, ainda hoje a mais pesada entre os parceiros do Mercosul; d) ampliação do setor privado no processo de integração. e) criação de uma faixa de variação 
cambial; e) melhoria na infra-estrutura de transportes, armazenagem e energia; e f) implantação de políticas de reconversão. 


\section{MERCADOS FUTUROS}

A nivel mundial as operações de compra e venda de commodities agrícolas no mercado futuro são realizados em grandes bolsas internacionais. Os volumes transacionados mostram que os mercados futuros vem servindo como instrumento eficaz para o aperfeiçoamento da comercialização de mercadorias agropecuárias, como mostram os volumes negociados na Bolsa de Mercadorias de Chicago (Chicago Board of Trade - CBOT) que supera largamente a produção agropecuária americana. . Em 1.987, por exemplo, a Bolsa de Chicago girou 19,3 vezes a safra de soja dos EUA, 5,2 vezes a de milho e 8,6 vezes a de boi gordo. Passam então a ter papel fundamental de referência negocial na comercialização, sem ser, contudo, lugares orientados para as transações físicas de mercadoria. Forte indicativo deste papel a que se prestam as bolsas de futuros é que apenas cerca de $3 \%$ dos negócios realizados são efetivamente liquidados através da entrega física da mercadoria (CHICAGO BOARD OF TRADE, 1992, p.36).

Este capítulo será então dividido em cinco partes. Na primeira, serão apresentadas as condições necessárias para um produto ser negociável em bolsas de mercados futuros; na segunda parte, o hedge e as principais vantagens e benefícios geradas a partir de operações com mercados futuros; na terceira, serão apontadas as restrições e dificuldades para a implantação deste mercado, procurando associar estes aspectos às características práticas da cadeia do milho no Brasil. Finalmente, nas quarta e quinta partes serão ordenados, a partir do estudo descrito neste capítulo e no anterior, os aspectos 
favoráveis e desfavoráveis para a implantação e desenvolvimento de um mercado futuro de milho no Brasil.

\subsection{Condições para o funcionamento do mercado}

Segundo TEIXEIRA (1992) várias são as condições necessárias, embora não suficientes, para que um novo contrato seja bem sucedido. As principais delas são:

a) Atomização do mercado: tanto a produção quanto o consumo da commodity objeto de negociação devem estar distribuídos entre um grande número de produtores e processadores ou consumidores. Caso haja também um grande número de distribuidores, tanto melhor, de tal forma que o mercado seja realmente competitivo, evitando que poucos participantes possam, em função da sua atuação, ditar os preços praticados no mercado.

b) Ausência de controle governamental, de tal forma que exista incerteza quanto aos preços futuros, sem que qualquer ação do governo possa modificar constantemente as características do mercado.

Conforme já discutido na introdução deste trabalho, o governo tem demonstrado clara intenção de diminuir a intervenção na atividade agrícola. Enquanto na década de 70 o volume de recursos anuais ultrapassava os 20 bilhões de dólares, atualmente este montante gira em torno de 5 bilhões, bem aquém, portanto, das necessidades do setor. Além do crédito, um outro instrumento de política agrícola é a política de garantia de preços mínimos (PGPM). Segundo BERALDO (1993) esta política deve ser vista como etapa fundamental na política de combate à inflação, na medida em que a escassez de recursos para bancá-la tem aumentado sensivelmente a variação estacional dos preços agrícolas, não preservando a renda dos produtores nem protegendo parte da população da instabilidade dos preços dos alimentos. Já LOPES (1994) acredita que não há como discutir políticas agroindustriais no contexto de um Estado empreendedor, intervencionista e regulamentador, em 
um quadro de abertura econômica. Neste caso, a formação de estoques públicos perde muito seu sentido em função da formação de um mercado comum onde, em princípio, os excedentes formados em um país podem aliviar a escassez em outro país membro. Ainda segundo LOPES, uma contribuição da política de preços mínimos poderia ser dada na estabilização dos preços agrícolas. Como garantia de última instância, poderia evitar quedas abruptas de preços. Mas, mesmo neste caso, "a estabilidade de preços poderia advir de um funcionamento mais eficiente dos mecanismos de operações em bolsas, de mercado a termo e de hedging de preços em mercados futuros"(LOPES, 1994, p.38).

Ainda com relação aos preços mínimos REZENDE (1992) afirma que uma vez que essas decisões, a julgar pela experiência passada, são muito condicionadas por outros objetivos de ação governamental (controle monetário, controle de preços) em geral conflitantes no curto prazo, com o objetivo de garantia de renda agrícola, o resultado final é que política de preços mínimos, em vez de ser um instrumento de redução de risco, transforma-se no seu contrário, ou seja, numa fonte de incerteza de renda agrícola".

LOPES (1992) descreve que 'tomo estas intervenções eram virtualmente imprevisiveis, o governo criou no mercado um risco institucional, acima dos riscos normais de um mercado que já é, por natureza, muito volátil".

c) Facilidade de padronização: A commodity objeto de negociação a futuro deve oferecer condições para uma fácil padronização de qualidade, quantidade, peso e outras características.

d) Atuação ativa dos participantes do Mercado Físico: É fundamental que produtores, distribuidores e processadores atuem no mercado futuro de modo a garantir que os preços futuros guardarão uma relação lógica com os preços a vista e, por conseguinte, ambos convergirão para um mesmo nivel na data de liquidação. 
e) Volatilidade dos preços da commodity: Quanto mais volátil o preço de um bem, maior a incerteza quanto a seu preço futuro, gerando maior estímulo para sua negociação para liqüidação futura.

SCHOUCHANA (1995) acrescenta algumas condições necessárias para um bom desempenho deste mercado:

- que haja um mercado à vista relativamente organizado, capaz de transferir aos mercados futuros a transparência da formação de preços;

- que não haja outro mecanismo de hedge capaz de substituir o mecanismo de mercado futuro de maneira mais segura;

- que haja um número suficientemente importante de corretores e consultores que estejam habilitados para executar a tarefa de montar estratégias operacionais capazes de resolver os problemas dos agentes interessados e de realizá-los na Bolsa;

- que a Bolsa esteja habilitada técnica, econômica e profissionalmente para servir de palco das forças do mercado, com poderes para exercer a autoregulação, para lidar com o governo, para evitar que o mercado sofra grandes inadimplências capazes de destruí-lo, e garantir que todas as liqüidações sejam realizadas corretamente e, finalmente,

- que o contrato seja corretamente desenhado pela Bolsa.

\subsection{Benefícios dos mercados futuros}

Dentre os benefícios dos mercados futuros há que se destacar o papel do hedging ou "proteção" dos agentes participantes, ou seja: os produtores, distribuidores e processadores do produto físico. A função básica dos mercados futuros é permitir que aqueles agentes com interesse comercial em determinada commodity se utilizem das bolsas para se "defender" de variações adversas de preços que possam ocorrer no futuro; a esta operação dá-se o nome de hedging, de tal forma que o agente assume uma posição (de venda ou compra) no mercado físico e uma posição contrária no mercado futuro. Assim, 
a grosso modo, no caso de um produtor que, no momento do plantio, resolve se proteger contra possiveis oscilações de preços deveria vender contratos futuros (hedge de venda) de modo que, como os preços futuro e disponivel tendem a movimentar-se de maneira paralela, um declínio no preço do mercado futuro resultará em um ganho neste mercado, que liquidará aproximadamente a sua perda no mercado disponivel. Como resultado, então, a venda no mercado futuro protege a posição do hedger no mercado disponivel se o preço declinar. Raciocínio inverso pode ser feito para o hedge de compra para distribuidores e processadores. Com o objetivo de fixar um entendimento oficial sobre o termo e sobre a operação, a Commodity Future Trading Comission - CFTC definiu o hedge como sendo a tomada de posição em mercado futuro oposta à posição assumida no mercado à vista, para minimizar o risco de perda financeira decorrente de alterações de preços adversas; a compra ou venda de futuros como substituta temporária de uma transação à vista que venha a ocorrer mais tarde"(FORBES, 1991). Finalmente, para que esta operação seja efetivada é necessário que exista e, em grande número, a presença do chamado especulador que é quem vai dar liquidez ao mercado e, em última instância, quem vai assumir o risco transferido pelos hedgers.

O hedge poderia então trazer benefícios diretos aos produtores $\mathrm{e}$ processadoras na medida em que as operações com produtos agrícolas geralmente demandam intervalos de tempo relacionados a safras e entressafras além de estarem sujeitos a grandes oscilações de preços ao longo do ano. Os comerciantes de milho, de um modo geral, podem se utilizar deste instrumento para proteger o custo desta mercadoria, ainda não adquirida, contra um possivel aumento antes que ela seja comprada. Esta operação, denominada de hedge de compra, pode ser utilizada por todos agentes que comprem milho: indústria de esmagamento e de rações, avicultores, suinocultores, confinadores, traders etc. Este tipo de operação é muito útil especialmente para as empresas que fazem contratos a prazo com seus 
clientes já que protege os custos do milho que será adquirido para cumprir com tais contratos.

A compra de mercados futuros, no entanto, envolve a análise dos chamados "custos de carregamento". No chamado mercado normal, quanto mais distante for o mês da compra deste produto maior será este custo, e o valor desta diferença informará ao agente quanto o mercado pagará para se "Carregar" este milho até uma determinada data em função dos custos relacionados à armazenagem, taxas de juros e seguros. No mercado efetivo, o spread entre os meses pode variar conforme a situação de abastecimento e os custos de carregamento serão indicativos de uma situação média que exista no mercado em um momento especifico e das expectativas quanto à oferta e demanda pelo produto nos meses futuros. Em casos de grande escassez ou desaparecimento da commodity os custos de carregamento poderão desaparecer ou até mesmo serem negativos, caracterizando o chamado mercado invertido, pois o mercado pagará um prêmio pela entrega imediata em função de sua escassez.

No caso do milho, considerado uma cultura anual, a inversão ocorrerá no último mês de vencimento dos futuros de uma safra e o próximo mês de vencimento da safra do ano seguinte, em função da mudança de situação no abastecimento pela entrada da nova safra. Assim, é de se esperar que, no Brasil, em situações normais o preço futuro deste produto em abril de um certo ano esteja, por exemplo, abaixo do mês de dezembro do ano anterior, e o tamanho desta inversão será em função da expectativa do tamanho da nova safra e dos estoques remanescentes.

Assim, a análise dos custos de carregamento, as expectativas de oferta e demanda do produto nos meses seguintes e a direção do mercado (normal ou invertida) é fundamental para a decisão do comerciante quanto à opção pela utilização do hedge nos mercados futuros.

Outro aspecto a se considerar é a chamada base", que é a diferença entre o preço à vista de determinada commodity, em um local específico, e o 
seu preço futuro e é função de uma série de variáveis como: o custo do transporte entre o ponto de entrega e o de produção, disponibilidade do produto no local de entrega, condições das estradas, espaço disponivel de armazenamento, ritmo de comercialização da safra entre outros. Desta forma o hedge não é capaz de eliminar completamente os riscos de variações de preços porém limita-os à diferença entre o preço à vista e o preço futuro de uma commodity ou seja, o risco da base é menos volátil e mais previsivel que as flutuações dos preços à vista e a futuro.

Além destes agentes citados, outro beneficiário direto poderia ser 0 governo que poderia atuar através do lançamento de contratos de opções de compra e venda, agindo, desta forma, de maneira clara e previsível e evitando incertezas aos agentes. Assim, através do lançamento de opções de venda, garantiria preços mínimos ao produtor, diminuindo custos de carregamento de estoques com o recebimento do prêmio, assim como custos administrativos já que o gerenciamento dos estoques seria de responsabilidade do produtor até 0 vencimento destes títulos. Por outro lado, SCHOUCHANA (1995) também sugere que outra alternativa de atuação do governo no mercado seria através da participação direta no mercado de opções, vendendo opções de compra (calls) dos seus estoques de forma que receberia o prêmio das opções e diminuiria o custo de armazenagem e conservação de seus estoques. Assim, se o preço de mercado no vencimento das opções caísse abaixo do preço de exercício estipulado pelo governo, o comprador não iria exercer a call e o produto continuaria armazenado, a um custo mais baixo. Se o preço subisse acima do preço de exercício da opção, o comprador iria exercer a opção adquirindo o produto do governo ao preço de exercício. Desta forma, através deste dois instrumentos, o governo estaria abastecendo o mercado, impedindo o preço de subir acima de um certo patamar e segurando uma possível pressão inflacionária e, por outro lado, garantindo um preço mínimo para o produtor de forma transparente e previsível e evitando especulações no mercado. 
Além da diminuição de riscos que a operação de hedge pode oferecer aos agentes, um outro tipo de benefício poderia ser gerado: a alavancagem de recursos para financiamento de safras. Esta operação, amplamente utilizada nas últimas safras pelos agentes da soja, poderia ser estendida ao milho caso houvesse um mercado futuro desta commodity no Brasil. Assim, através da diminuição de riscos ocasionada pela operação de hedge, os agentes compradores do grão (processadores, exportadores e cooperativas), podem financiar a sua produção, com benefícios mútuos já discutidos no item sobre relações contratuais entre os agentes. As exportadoras que realizam venda futura de soja compram contratos no mercado futuro como forma de se resguardar contra aumentos de preços na CBOT, na medida em que se observa uma relativa paridade entre os preços cotados nesta bolsa e os praticados internamente no Brasil, conforme pode-se observar na figura 10. Assim, apesar de eventuais "descolamentos" de preços que ocorrem em função de conjunturas locais ao longo do ano, esta operação tem sido executada com êxito pelas empresas, que conseguem obter outras compensações financeiras, como arbitragens de juros através do diferencial existente, nos últimos anos, entre os juros praticados internamente e aqueles utilizados na captação de recursos no exterior e nos adiantamentos de contrato de câmbio (ACC).

Esta operação, no entanto, não encontraria respaldo técnico para o caso do milho, em função da não paridade entre o preço deste produto no mercado interno e o praticado na CBOT, pois não sendo este um produto de exportação, a formação de preços da commodity milho baseia-se, dentro de uma certa faixa de flutuação, basicamente em função de fatores internos, como os descritos no item de formação e comportamento de preços. Na figura 11, pode-se visualizar a comparação das oscilações de preços mensais internos e externos do milho entre os anos de 1984 e 1995, cujo índice de correlação (r) entre eles é de 0,31 contra um índice de correlação superior, de 0,80 , no caso da comparação entre os preços da soja no Brasil e EUA, no mesmo período. 


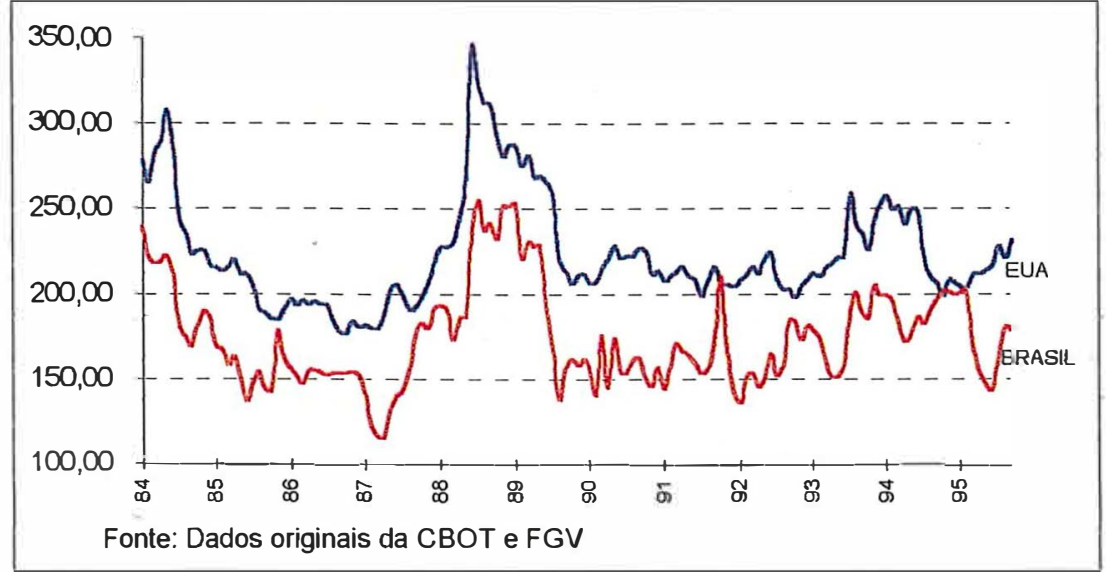

Figura 10. Preços mensais da soja no Brasil e EUA entre 1984 e 1995 em US $\$ /$ t, valores nominais.

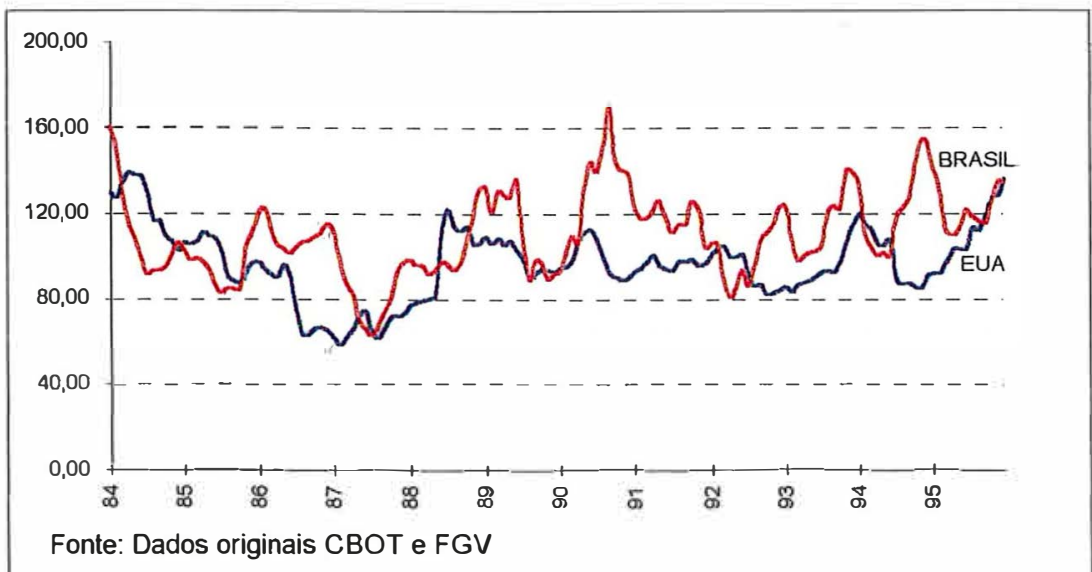

Figura 11. Preços mensais do milho no Brasil e EUA entre 1984 e 1995 em US $\$ / t$, valores nominais.

Esta situação, de uma certa forma, poderia até favorecer o sucesso no desenvolvimento de um mercado futuro de milho em relação ao da soja, pois apesar das dificuldades iniciais pela não tradição deste mecanismo entre os 
agentes do milho, não resta a eles outra opção de mercado futuro, diferentemente dos agentes da soja que podem se utilizar de um mercado já extremamente líquido e transparente, como o da CBOT. A comparação dos preços internos e externos permite também constatar que a correlação entre eles aumenta quando se compara diferentes sub-períodos nos últimos vinte anos, tanto para a soja quanto para o milho, possivelmente em função de uma maior inserção do Brasil na economia mundial.

Ainda como uma outra fonte de benefício indireto proporcionado pelo hedge poder-se-ia citar a maior facilidade de obtenção de crédito para financiamento de safra ou crédito com encargos preferenciais junto aos agentes financeiros para os produtores que se protegessem nas bolsas de futuros, em função de menor risco de crédito assumido por estas instituições. Deste modo os bancos saberiam, com pequena margem de erro, o preço que este produtor receberia por seu produto garantindo assim o pagamento do empréstimo, desde que este produtor estivesse assegurado contra perdas de sua produção. Nesta operação seria interessante que o financiamento cobrisse não só os custos de produção, como também que houvesse um crédito rotativo a fim de prover o produtor de meios financeiros para pagar os ajustes diários que se fizessem necessários, quando houvessem variações nos preços. Segundo POWERS (1977) no entanto, alguns aspectos devem ser observados nesta transação:

- uma operação de hedge não fará com que um mau empréstimo se torne um bom empréstimo, de forma que ele deve ser analisado exclusivamente com base na viabilidade do projeto e não pelo fato de se foi feito hedge ou não.

- o hedge não deve ser feito por qualquer produtor, mas principalmente por aqueles que detêm certo conhecimento do mercado físico e futuro.

- tanto o hedger quanto seu financiador devem fazer uma boa análise dos custos de operação do projeto e suas margens de lucro em qualquer operação de hedge. 
Um outro aspecto importante nesta transação é que o agente financiador tenha absoluto controle sobre a operação de seu financiado na medida em que experiências neste sentido demonstram que um grande risco nesta operação é que o produtor, em algum momento, seja tentado a especular, mudando de posição antes do final da operação quando acreditar que poderia auferir maiores lucros agindo desta forma.

Além desses, outros benefícios poderiam ser mencionados com a implantação de um mercado futuro:

- Sinalização dos preços, que pode ser usada por todos os agentes da cadeia agroindustrial para alocar os recursos reais. A informação de preços, sem dúvida, é uma das maiores contribuições dos mercados futuros para a eficiência do fluxo do produto. Estes mercados são eficientes coletores, processadores e disseminadores de informações, uma vez que os preços nos mercados futuros tornaram-se uma grande referência para a fixação dos preços correntes nas relações de trocas domésticas e internacionais das commodities e seus derivados. Os produtores e as agroindústrias que assumem posições nos mercados futuros estão sempre ajustando suas ofertas de compra e venda de contratos, tendo por base o fluxo contínuo de informação sobre mercados regionais, nacionais e mundial (Chicago Board of Trade, 1985).

TSUNECHIRO (1983), avaliando o desempenho da função preçoantecipatória dos mercados a termo de café, soja e boi gordo concluiu que, nos casos do café e boi gordo, para as 4 primeiras defasagens, os preços dos respectivos mercados a termo foram eficientes prognosticadores dos preços à vista esperados para a data de vencimento dos contratos. No caso da soja, os preços de contrato a termo foram eficientes prognosticadores de preços para defasagem de até 12 meses.

Posteriormente, ATRASAS (1993), analisando os mercados futuros de algodão, boi gordo, café e soja no Brasil conclui que: a) as operações em mercado futuro aumentam a quantidade de informações entre os comerciantes; b) baseados nas informações de mercado quando há o mercado futuro os 
preços são melhor refletidos tornando o mercado à vista mais eficiente; e c) o comportamento dos preços dá suporte à hipótese de que produtores e consumidores seriam favorecidos pelas informações das variações de preços nas operações em mercado futuro.

- Redução dos preços dos bens: TEIXEIRA (1992) acredita que os agentes que operam com produtos que envolvem maiores riscos, como as commodities agrícolas, demandam maior rentabilidade em função destes riscos a que estariam expostos. Assim, na medida em que estes agentes pudessem trabalhar com maior segurança quanto aos preços futuros, parte destas margens utilizadas para cobrir estes riscos poderia ser eliminada ocasionando, desta forma, redução dos preços deste produto.

\subsection{Principais dificuldades para implantação dos mercados futuros}

Os mercados futuros agrícolas no Brasil têm tido muito pouca importância em detrimento de outros mercados já bastante consolidados como, por exemplo os mercados de juros interbancários "DI", dólar comercial, índice Bovespa e ouro. Considerando-se apenas os meses de outubro, novembro e dezembro de 1995, período em que a BM\&F já contava com quatro mercados agropecuários (café, boi, soja e açúcar), estes contratos representaram apenas $0,13 \%$ do total de contratos futuros negociados no período (Tabela 17). Além disso, vários mercados futuros de commodities agrícolas deixaram de existir por falta de negócios como no caso do algodão, do frango, do suíno, do bezerro e da própria soja por duas vezes, relançado em outubro de 1995.

Várias são as causas que podem gerar eventuais insucessos destes mercados. HIERONYMUS (1977) cita cinco delas:

a) Um mercado pode acabar por proibição legal. Foi o caso do mercado a termo da cebola nos EUA e que quase atingiu também a batata. As razões dessas proibições são decorrentes de tentativas de manipulação aproveitando a alta perecibilidade desses produtos. 
b) Os mercados falham porque perdem sua base econômica. 0 mercado se origina das necessidades de se proteger contra riscos e sua dimensão é determinada pela intensidade do uso do hedge. Quando a necessidade de uso pelos hedgers diminui, o mercado declina e desaparece. SANTOS FILHO (1982) acredita que a principal causa do desaparecimento do mercado futuro de algodão no Brasil encontre ressonância nesta hipótese.

Tabela 17. Número de contratos futuros negociados na BM\&F (1994/95).

\begin{tabular}{lrrrrr}
\hline Commodity & 1994 & 1995 & $\begin{array}{c}\text { início } \\
\text { contrato }\end{array}$ & \multicolumn{1}{c}{ out-nov-dez } & (\%) \\
\hline Ouro fut. cambial 1 kg & 134.240 & 607.288 & 305.635 & 0,95 \\
Juros - DI de 1 dia fut. & 28.474 .764 & 35.152 .630 & 9.943 .098 & 30,88 \\
Dólar comercial futuro & 39.124 .825 & 73.930 .297 & 18.060 .034 & 56,09 \\
Dólar flutuante futuro & 106.919 & 311.070 & 201.430 & 0,63 \\
Ibovespa futuro & 10.583 .594 & 15.304 .666 & 3.649 .389 & 11,33 \\
Total & 78.424 .342 & 125.305 .951 & 32.159 .586 & 99,87 \\
& & & & & \\
Café cambial futuro & 79.220 & 76.206 & 16.653 & 0,05 \\
Boi cambial futuro & 5.687 & 39.174 & maio/94 & 17.743 & 0,06 \\
Soja cambial futuro & - & 3.750 & out./95 & 3.750 & 0,01 \\
Açúcar cristal cambial & - & 4.301 & set./95 & 3.860 & 0,01 \\
Total Agropecuários & 84.907 & 123.431 & 39.498 & 0,13 \\
& & & & & \\
Total & 78.509 .249 & 125.429 .382 & 32.201 .592 & 100,0 \\
\hline
\end{tabular}

Fonte: Bolsa de Mercadorias e Futuros - BM\&F

Quando o governo estabelece um preço mínimo acima das cotações internacionais, ele estará de certa forma congelando o preço pois não cai porque o governo compra e não sobe porque já está acima do valor de mercado. Assim, se não há variação de preço, não haverá risco para justificar o hedge, que é, em última instância um seguro contra alteração de preços.

c) Os mercados podem falhar por causa de fraqueza nos termos do contrato, dando vantagem aos compradores ou aos vendedores. Se os termos 
do contrato não estiverem equilibrados eles possibilitarão ao comprador ou ao vendedor pressionar a outra parte no sentido de obtenção de contínuos lucros às expensas do outro, desencorajando uma das partes que perderá o interesse em continuar operando. Este parece ter sido um dos motivos de insatisfação dos produtores de soja quanto ao contrato futuro desta commodity, que determinava apenas um ponto de entrega do produto dificultando dessa forma sua operacionalização.

d) Os mercados futuros podem falhar quando são boicotados por interesses comerciais, pois a transparência de preços pode não agradar a certos setores com maior nivel de concentração. O desenvolvimento de um mercado futuro ativo representa um aumento na competição e é normal que surja entre produtores e comerciantes alguma reação a essa maior competitividade. Posteriormente, com o aumento dos negócios, serão estes operadores que darão suporte ao mercado. É necessário porém, um equilíbrio de interesses para que todos se submetam aos riscos e à eficiência de preços de mercado.

e) Os mercados podem falhar em atrair especuladores. As posições de compra e venda estabelecidas pelos hedgers não surgem de forma simultânea. Os especuladores têm a oportunidade de equilibrar as posições dos hedgers proporcionando liquidez.

Outros fatores podem ser apontados como causa de insucesso destes mercados:

- Entraves de ordem cultural: com exceção das indústrias e exportadores de soja e laranja que atuam em mercados futuros no exterior, de um modo geral, persiste uma resistência muito forte por parte de produtores e processadores a estes mercados. GALJART (1972) destaca a importância de fatores e não de conceitos para se entender o processo de adoção de novas tecnologias nos países subdesenvolvidos. Deste modo, destaca os seguintes elementos que podem constituir-se em obstáculos à adoção de inovações tecnológicas no meio rural: 
- ignorância: o indivíduo não adota porque não conhece.

- incapacidade: o indivíduo conhece a inovação, mas não adota porque não pode.

- desinteresse: o indivíduo conhece a inovação, pode utilizá-la mas não adota. Uma das vantagens deste modelo é permitir distinguir entre diferentes classes de fatores que impedem o desenvolvimento, e que requerem diferentes remédios. A ignorância pode ser combatida com a disseminação dos conhecimentos; a incapacidade com medidas estruturais como, por exemplo, crédito para depósitos de margens e ajustes diários, mudanças na política fiscal e tributária e melhoria na infra-estrutura; finalmente, o desinteresse com doutrinação cultural.

- Desuniformidade de tratamento fiscal entre os estados em termos do valor de pauta e da alíquota do ICMS. Em relação a esta distorção, NÓBREGA et al. (1990, p.36) conclui que "não há um paralelismo entre os preços nos diferentes mercados físicos e o preço futuro devido ao tratamento desigual do ICMS. Alíquotas internas diferenciadas distorcem a formação de preços, particularmente de commodities agrícolas". De fato, como os valores dos contratos no mercado futuro devem refletir o preço a vista excluido o ICMS, na medida em que não exista a neutralidade deste imposto, o preço final será desconhecido do comprador. Assim, se o comprador não tiver certeza sobre o volume de imposto a ser pago, a procura por operações no mercado futuro se reduzirá. NÓBREGA enfatiza também que "uma das razões para que o contribuinte evite as bolsas de mercadorias é que a imposição de alíquotas elevadas não estimula os contribuintes a recolherem voluntariamente o imposto. Pelo contrário, há uma relutância ao seu pagamento" . E por fim, sugere que "o ICMS necessita ser absolutamente neutro e com aliquotas menores para anular os impactos negativos sobre os mercados físicos e futuros. Para isto é necessário que este imposto tenha uma mesma base tributária e uma aliquota uniforme aplicada a essa base, nas etapas 
intermediárias do setor produtivo, e que o ICMS a ser recolhido esteja dentro dos limites da capacidade de pagamento dos contribuintes, impedindo que o atrativo da sonegação marginalize importantes agentes do mercado".

- Falta de internacionalização das Bolsas, o que permitiria gerar maior liqüidez e transparência a estes mercados.

- Outro aspecto importante a ser considerado é a deficiência da infraestrutura de comercialização existente no Brasil como transportes, armazenagem, portos etc.

Assim, após esta análise preliminar da cadeia do milho bem como das pré-condições para se implantar um mercado futuro, seus benefícios e dificuldades, pode-se tentar enumerar os principais pontos favoráveis e desfavoráveis para a existência deste mercado, enfatizando as características já descritas.

\subsection{Aspectos favoráveis}

1) Alto valor da produção. Em 1995 a receita agrícola do milho foi de cerca de 4,4 bilhões de reais, a principal cultura em valor de produção, superando inclusive a soja. Tomando-se como base a movimentação de contratos no mercado futuro de milho no CBOT, pode-se imaginar um volume de contratos equivalente a cinco vezes este montante, ou cerca de 22 bilhões de dólares ao ano.

2) Potencial de crescimento da produção, seja em função da tendência de incorporação de novas áreas, seja pelo contínuo aumento da produtividade ao longo dos últimos anos através do desenvolvimento e-adoção-de novas tecnologias. Este crescimento da produção estaria condicionado ao aumento da demanda interna e externa. O aumento da demanda interna pode se dar pela melhoria do poder aquisitivo da população cujo consumo de proteína animal ainda se situa bem abaixo dos níveis recomendados pelos organismos internacionais. Expressivo crescimento já pode ser detectado em 1995 
quando, segundo a Associação Paulista de Avicultura - APA, o consumo per capita de carne de frango subiu de 18 para $22,5 \mathrm{~kg}$, denotando um aumento de $24,5 \%$ em relação ao ano anterior. Quanto ao aumento da demanda externa, apesar deste cereal não ser competitivo para exportação, em função de nossa ainda baixa produtividade e das distorções geradas pelas questões tributárias e cambiais, o país tem se demonstrado extremamente competitivo na transformação de grãos em carne de frango para exportação, sendo o milho insumo básico para fabricação de ração para aves. Segundo a Associação Brasileira dos Exportadores de Frango (ABEF), o Brasil é atualmente o quarto maior exportador mundial deste produto em volume embarcado, atrás dos EUA, França e Hong-Cong, este último um importador e reexportador do produto, principalmente para a China. Em faturamento o Brasil é o terceiro, atrás dos EUA e França.

3) Grande diversificação de utilização do milho e elevada pulverização do mercado produtor e processador; O milho é o cereal que apresenta a mais diversificada utilização na alimentação humana e animal, com mais de 500 derivados, muitos dos quais se prestam a diversos empregos em diferentes indústrias. Seus principais consumidores são as indústrias de ração, as moageiras de milho sob a forma seca e úmida, as avícolas e suinícolas, além do consumo humano in natura, setores estes que, excetuando-se a indústria de milho úmido, caracterizam-se por apresentar médio e baixo nível de concentração.

4) Tendência declinante de retenção do produto nas propriedades para autoconsumo e, conseqüentemente, maior destinação do milho para o mercado denotando uma maior integração do produtor à agroindústria.

5) Alta volatilidade e liquidez do produto no mercado físico, condições fundamentais para o sucesso do mercado futuro. Análise da amplitude e desvio padrão de sete principais produtos agropecuários (milho, soja, boi gordo, cana-de-açúcar, algodão, café beneficiado e feijão) demonstra que o 
milho é o que apresenta, na média, o segundo maior índice no período de 1987 e 1996, ficando atrás apenas do feijão (tabela 13).

6) Falta de concorrência com Bolsas internacionais, onde a correlação entre os preços praticados internamente e preços externos é baixa na maior parte do tempo. Diferentemente do milho, os operadores de soja podem se utilizar da Bolsa de Chicago (CBOT) protegendo-se contra oscilações de preços internos em operações de hedge em função da alta correlação entre os preços praticados no país e as cotações internacionais, cujos movimentos são bem próximos na maior parte do ano (figuras 10 e 11), além de sua grande transparência e liqüidez.

7) Alternativa de financiamento, liberando o governo do pesado ônus do financiamento da totalidade de custeio para o plantio do grão, cujas necessidades atuais superam os 3 bilhões de dólares anuais. Excetuando-se algumas empresas moageiras, que praticam a troca de produto por sementes, de um modo geral não existe autofinanciamento no setor, o que poderia ser incrementado com a existência de um mercado futuro, através da diminuição dos riscos incorridos pelas empresas. Desta forma elas poderiam repassar parte deste benefício aos produtores através de melhor remuneração nas compras antecipadas ou melhores condições nas trocas por insumos. Os mercados futuros e de opções poderiam ser utilizados também como um importante complemento aos títulos representativos de mercadorias (como o CM-G e CPR) beneficiando o produtor através de uma melhor sinalização de preços futuros e maior disseminação de informações sobre o mercado. A agroindústria seria beneficiada pela utilização de hedge e conseqüente minimização dos riscos de flutuações de preços na época do recebimento do produto.

8) Perspectiva de estabilidade econômica, o que favoreceria as aplicações em ativos reais em detrimento dos ativos financeiros, bastante atrativos em situações de instabilidade da moeda. A experiência argentina mostra que a movimentação de contratos futuros de commodities agrícolas naquele país 
apresentou grande crescimento no Mercado a Termino - MAT de Buenos Aires com a estabilização econômica. Até o ano de 1990 eram negociadas 1,2 milhão de toneladas de contratos futuros de milho ao ano; já em 1991, com o lançamento do "plano Cavallo" e a conseqüente queda da inflação, este número subiu para 4,5 milhões de toneladas, atingindo o patamar de 6 milhões de toneladas a partir de 1993, ou mais da metade de toda a safra argentina deste cereal'. No Brasil, apesar da pequena participação no total de contratos negociados, o mercado futuro de produtos agropecuários na BM\&F foi um dos que mais cresceu em 1995, superando em $45 \%$ o volume registrado no ano anterior (BRANCO, 1996).

9) Maiores garantias para as instituições financeiras; os bancos poderiam condicionar a liberação de empréstimos de custeio para o produtores à proteção ou hedge nas Bolsas de futuros de forma a, com pequena margem de erro, poder garantir o preço de seus produtos por ocasião da colheita, minimizando os riscos envolvidos. Este tipo de operação, no entanto, deve ser bem analisado pelo banco quanto à viabilidade do projeto além de proceder um rigoroso acompanhamento das movimentação de ajustes diários, já que experiências internacionais têm demonstrado que muitas vezes o produtor é tentado a especular, mudando de posição antes do final da operação com objetivo de tentar auferir maiores lucros. A prática de hedging e 0 desenvolvimento de um modelo de seguro de produção barato e eficiente poderiam resultar em menores riscos de inadimplência para as instituições financeiras e, conseqüentemente, a possibilidade de menores spreads cobrados pelos bancos.

\footnotetext{
${ }^{1}$ Comunicação pessoal
} 


\subsection{Aspectos desfavoráveis}

1) Entraves de ordem cultural e dificuldades de comunicação; percebe-se uma resistência natural dos produtores a estes mercados, basicamente em função da desinformação dos mecanismos que os cercam, assim como preconceito quanto à ação dos especuladores que são vistos como manipuladores do mercado. Na verdade, estes agentes são fundamentais para viabilidade do mercado futuro pois são eles quem dão a liquidez necessária às bolsas, assumem os riscos transferidos pelos hedgers e atenuam as oscilações de preços. A este fator pode-se adicionar a barreira de comunicação existente entre o homem do campo e os executivos das cidades, com hábitos e costumes tão diversos.

2) Falta de conhecimento e motivação das corretoras em atuar em mercados agrícolas, optando por operar com ativos financeiros.

3) Desuniformidade de política fiscal, com diferenciações de pauta e alíquotas entre os estados gerando distorções nos preços nos diferentes mercados físicos e o preço futuro, assim como elevadas alíquotas estimulando a sonegação fiscal.

4) Constantes intervenções governamentais no mercado, gerando incertezas nos agentes pela falta de regras claras e transparentes e conseqüentes distorções no mercado.

5) Falta de padronização do produto físico, dificultando a normatização do contrato futuro. Apesar da existência de normas que regulam esta padronização, elas não são aplicadas na prática. Analisando-se a questão do lado industrial, cada tipo tem seu perfil de aplicação, com tendências estabelecidas de acordo com os resultados de rendimento de cada processo industrial, que estão relacionados com a qualidade tecnológica do grão. Assim, é importante que haja uma uniformidade do grão em relação à aplicação destinada. Para a indústria moageira a úmido há melhor rendimento industrial 
para o grão dentado e mole, enquanto a indústria moageira a seco apresenta melhores rendimento quando utilizadas variedades de grão duro (MERCADO, Notícias ABIMILHO, 1995).

6) Inexistência de seguros agrícolas eficientes e acessiveis, hoje restritos praticamente ao seguro oficial - Proagro - que não tem atendido de forma eficiente às partes envolvidas (produtores e Banco do Brasil).

7) Falta de internacionalização das Bolsas, o que permitiria maior afluxo de capitais a estes mercados gerando maior liqüidez, transparência e atraindo maior número de especuladores internacionais ${ }^{2}$.

8) Infra-estrutura deficiente como estradas, portos e armazéns.

\footnotetext{
${ }^{2}$ Há atualmente impedimento de ordem legal para a abertura de capitais para as Bolsas de Futuros no
} Brasil. 
4 MATERIAL E MÉTODOS 


\section{MATERIAL E MÉTODOS}

Nos capítulos anteriores procurou-se detectar os benefícios $e$ as dificuldades da implantação de um mercado futuro de milho no Brasil através da confrontação das características da cadeia agroindustrial daquela commodity com a teoria e experiências práticas que descrevem as condições necessárias e as limitações para o desenvolvimento destes mercados. A partir destes resultados pode-se identificar os principais aspectos favoráveis e desfavoráveis, aspectos estes que nortearam as questões abordadas na pesquisa para a condução do presente trabalho.

Assim, as pesquisas exploratórias foram conduzidas junto aos principais agentes envolvidos, que se enquadrariam como participantes potenciais de um mercado futuro, que são: os produtores e os negociantes (traders) de grãos em cooperativas e agroindústrias (moageiras e de rações), como potenciais hedgers, e as corretoras de mercados futuros, já que compete a elas, além da intermediação financeira, a informação, o aconselhamento e a orientação de seus clientes. Basicamente estas pesquisas buscaram investigar cinco aspectos:

- verificar o nível de conhecimento e o grau de resistência dos produtores rurais quanto aos mecanismos de mercados futuros e hedge;

- avaliar a importância do papel das Bolsas de Futuros na alavancagem de recursos para financiamentos agrícolas;

- verificar o grau de motivação das corretoras com relação aos mercados futuros agricolas, com ênfase para o milho; 
- dimensionar o potencial destes mercados e identificar os principais entraves para o seu desenvolvimento, na visão dos atores e

- propor alternativas, através de sugestões dos agentes envolvidos e a partir de elementos obtidos na revisão literária.

\subsection{Descrição da amostra}

Quanto à escolha do plano amostral dos diferentes segmentos, algumas considerações gerais podem ser traçadas e expostas a seguir:

$\mathrm{Na}$ seleção das populações de produtores e traders de cooperativas foram entrevistados indiscriminadamente agentes que operavam tanto com o milho, objeto do presente estudo, como com a soja. Esta concessão foi permitida pois, dadas as características semelhantes de produção e comercialização destas duas commodities, seria possível ampliar o plano amostral sem prejuízo da análise e permitindo, inclusive, importante elemento de comparação. De fato, o produtor de soja, ao longo do tempo, é levado a fazer rotação de cultura, na maioria das vezes com o milho, seja por questões econômico-financeiras, seja por imposições agronômicas, prática esta facilitada pela utilização das mesmas máquinas e implementos bastando apenas algumas adaptações. Do ponto de vista das cooperativas, de uma maneira geral, as estruturas de comercialização de soja e milho são comuns pela semelhança de suas características: indiferenciação dos produtos, coincidência de épocas de plantio e colheita, mesma estrutura para armazenagem e transportes e, na maioria das vezes, mesmos fornecedores, o que gera uma grande afinidade entre as duas commodities. O fato de muitos destes traders já operarem ou terem operado em mercados futuros de soja na CBOT ou no Brasil possibilitaria, também, comparações enriquecedoras quando se questiona a potencialidade da implantação e desenvolvimento de um mercado futuro de milho no Brasil. 
A seleção dos três planos amostrais foi feita, então, segundo os seguintes critérios:

a) Produtores: Em função da grande heterogeneidade e dispersão geográfica desta população, optou-se por trabalhar com uma amostragem que satisfizesse certas condições para o presente estudo. Esta população-objetivo deveria ser composta por produtores cujo perfil se enquadrasse em algumas características desejadas que os qualificassem como potenciais hedgers. Assim, em função de dificuldades inerentes ao processo, como a necessidade de freqüentes contactos com os agentes de mercados e corretoras, dos custos iniciais e eventuais, dos ajustes diários e da razoável complexidade para a compreensão e acompanhamento dos mecanismos de mercados futuros, postulou-se que a população de produtores desejada deveria ser composta por respondentes com o seguinte perfil: médios e grandes produtores, com tecnificação elevada e atividade com caráter comercial, acesso à informação, formação acadêmica mais elevada, preferencialmente universitária, e jovem, mais propenso à adoção de novas tecnologias. Optou-se por entrevistar os assinantes da revista Preços Agrícolas, boletim mensal que divulga informações de mercado e análises conjunturais publicado pelo Centro de Pesquisa em Economia Agrícola da Fundação de Estudos Agrários "Luiz de Queiroz" - CEPEAFFEALQ cujo perfil médio se enquadrava nas características desejadas para a presente pesquisa. Segundo levantamento efetuado em novembro de 1994 com os assinantes apurou-se que apresentavam as seguintes caracteristicas:

- cerca de $35 \%$ tinham atividades relacionadas a milho e $29 \%$ relacionadas à soja, sendo que a área média de plantio destas duas culturas, por produtor, era de 796 ha. Verificou-se ainda que cerca de $66 \%$ recorria a capital de terceiros para o plantio de suas lavouras.

- apresentavam média de 13,41 tratores entre 0 e 10 anos, por produtor. 
- $58 \%$ apresentava nível universitário sendo que, destes, $70 \%$ tinham formação em engenharia agronômica, administração de empresas e medicina veterinária.

- a idade média dos respondentes da amostra era de 39,8 anos com desvio padrão igual a 10 anos.

A partir desta pesquisa pode-se estimar o número de assinantes produtores de milho e/ou soja, que é de cerca de 450 produtores, constituindose na população-objetivo de produtores rurais desta pesquisa. Assim, apesar da possibilidade de se incorrer em riscos de viés da amostra optou-se por aceitá-la já que há indicações de que o perfil de seus elementos sejam representativos daquele adequado aos objetivos anteriormente descritos, pela sua grande abrangência territorial e pela busca da melhor adequação do emprego de recursos financeiros disponiveis para a condução da presente pesquisa. Outra limitação para um melhor análise da presente amostra foi a carência de dados que melhor retratem o perfil do produtor e desatualização do Censo Agropecuário, do IBGE, cuja última edição data de 1985.

b) Traders de cooperativas e agroindústrias: Neste segmento, os questionários foram conduzidos junto aos responsáveis pela comercialização de soja e milhos das cooperativas que trabalham com estes produtos e agroindústrias moageiras e de rações. O critério para escolha das cooperativas pesquisadas foi o seguinte:

- Cooperativas: Foram selecionadas todas as cooperativas de produção da região Centro-Sul que constam do Anuário do Cooperativismo Brasileiro de 1994 e que discriminam o milho e a soja entre seus produtos, em um total de 179 empresas. O critério da região se deveu à sua representatividade quanto à produção de milho no país (cerca de $92 \%$ da produção brasileira, segundo tabela 4).

- Para as agroindústrias utilizou-se como critério de seleção a totalidade das empresas que participavam de associações e sindicatos considerados como representativos dos setores. A amostra foi, então, dividida em indústrias 
moageiras de milho associadas da Associação Brasileira das Indústrias Moageiras de Milho - ABIMILHO, em um total de 16, e indústrias de rações associadas ao SINDIRAÇÕES (cuja produção de ração representa cerca de $40 \%$ da produção nacional) e ANFAR, totalizando 142 e 31, respectivamente, quando consideradas apenas as empresas que utilizam o milho como insumo na sua fabricação. No total foram enviados, então, 368 questionários a traders, sendo que, destes, 189 representavam indústrias e 179, cooperativas.

c) Corretores: Foram selecionadas todas as corretoras de mercados futuros autorizadas a operar na Bolsa de Mercadorias e Futuros - BM\&F e membros de compensação desta instituição em um total de 173.

\subsection{Descrição do questionário}

Foi realizada uma pesquisa exploratória através de questionários que continham tanto respostas fechadas de múltiplas escolhas e de escalas, que pudessem ser agregadas e tratadas por métodos estatísticos, quanto questões abertas, com justificativas e sugestões, as quais foram agrupadas e quantificadas (Apêndices 5, 6 e 7). Procurou-se elaborar questionários concisos, diferenciados para cada um dos três segmentos estudados, limitando-se à abordagem de questões relevantes ao problema além da descrição do perfil do respondente.

\subsection{Condução da pesquisa}

Os questionários foram elaborados em gráfica e enviados via mala direta, o que permitiu uma maior abrangência numérica e geográfica da população-objetivo a um custo compativel com a disponibilidade de recursos do projeto. Inicialmente, nos meses de setembro e outubro foram enviados 12 pré-testes para elementos dos três segmentos, quatro de cada um, a fim de se verificar se estavam adequados e identificar outros problemas específicos do 
processo. Após o retorno dos mesmos foram contactados os respondentes, por telefone, e discutidas as perguntas, ocasião em que procurou-se identificar as eventuais dificuldades para respondê-las como o nível de complexidade, tempo necessário para respondê-las e críticas e sugestões ao questionário.

A todos os entrevistados do pré-teste e, posteriormente, os da pesquisa propriamente dita, foi prometido, como forma de estímulo, um brinde que seria enviado caso sua resposta fosse devolvida em um prazo de 7 dias a contar da data do seu recebimento. O brinde, que não era especificado na carta de apresentação, constituía-se de trabalhos e publicações que continham informações relacionadas aos mercados futuros e às cadeias agroindustriais do milho e da soja. Outra forma de incentivo foi a contratação de um sistema de carta-resposta junto aos serviços de correio, possibilitando ao entrevistado a remessa da resposta sem que incorresse em custos. MILLER (1977, p. 73) descreve pesquisa para se medir a taxa de retorno a questionários com estímulos para respostas e constatou que o retorno de questionários que continha uma moeda de US $\$ 0,25$ foi de $52 \%$, enquanto que o mesmo questionário sem o referido brinde apresentou retorno de $19 \%$. Afirma, também, que este retorno normalmente dobra com o envio de envelope selado para respostas. Opcionalmente, foi fornecido um número de fax para aqueles que preferissem esta forma de resposta.

A remessa dos questionários foi feita da seguinte forma:

- Produtores: os questionários foram enviados através de mala direta aos assinantes da revista Preços Agrícolas, encartados dentro da publicação do mês de novembro de 1995.

- Traders e corretores: Foram enviados diretamente pelo correio, através de mala direta fornecida pelas associações citadas no item 4.1, no mês de novembro de 1995. Posteriormente, no mês de janeiro de 1996 foram enviados novamente os mesmos questionários a todos os elementos, com objetivo de reforçar a primeira remessa. 
5 RESULTADOS

E DISCUSSÃO 


\section{RESULTADOS E DISCUSSÃO}

A fim de fazer a avaliação foram tabuladas as respostas e realizadas análises estatísticas descritivas e inferenciais, quando cabíveis, para cada um dos segmentos e divididas em três partes: na primeira procurou-se traçar 0 perfil dos respondentes, para sua melhor caracterização; na segunda, foram analisadas as opiniões dos entrevistados sobre as questões relevantes para a pesquisa e, na terceira, foram enumeradas suas sugestões para o desenvolvimento deste mercado. A despeito de um grande número de análises possiveis, procurou-se restringir a discussão aos problemas apontados como objetivos deste trabalho. Para efeitos didáticos, optou-se por fazer a discussão individualmente, por plano amostral.

\subsection{Produtores}

\subsubsection{Perfil dos produtores}

Considerando-se uma população-objetivo de cerca de 450 produtores rurais de milho elou soja, obteve-se um índice de respostas satisfatório de $19,11 \%$, com 86 respondentes. A amostra é constituída, basicamente, por grandes produtores com uma área média de plantio de soja e milho por produtor de 1.453 ha e possuidores de 12 tratores, na média. Observa-se, porém, que a variabilidade é muito grande na amostra, conforme tabela 18. 
Tabela 18. Tamanho das áreas de produção de milho e soja e número de tratores da amostra de produtores - mínimo, máximo, média e desvio padrão (média das safras 93/94 e 94/95).

\begin{tabular}{lcrcr}
\hline & mín. & máx. & média & desvio padrão \\
\hline Tamanho da área de plantio (ha) & 5 & 11.950 & $1.453,47$ & $2.151,00$ \\
Número de tratores & 1 & 42 & 11,90 & 12,19 \\
\hline
\end{tabular}

Fonte: Dados da pesquisa

As propriedades foram também distribuidas em função de seu estrato de área, conforme figura 12, onde pode-se observar que, apesar da área média ser de 1.453 ha, mais da metade do número de propriedades da amostra (54,7\%) se situa nos estratos até 500 ha, o que denota maior concentração de terras nas áreas maiores.

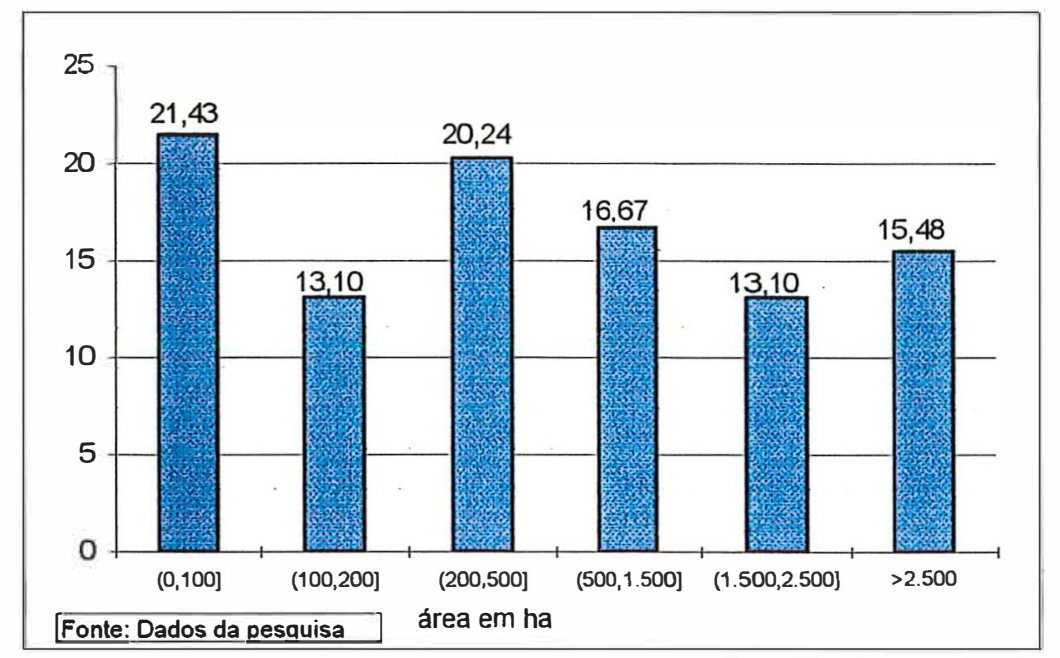

Figura 12. Distribuição das propriedades da amostra de produtores rurais, por estrato de área, em \%.

A região Centro-Oeste é a que apresenta maior área média com cerca de 3.114 ha, seguida das regiões Nordeste, com 2.487 ha, Sudeste e Sul com 936 e 871 ha, respectivamente. 
As propriedades localizam-se principalmente na região Centro-Sul $(97,7 \%)$, sendo que a região Sudeste abriga quase a metade das unidades de produção dos respondentes $(45,9 \%)$, segundo figura 13 .

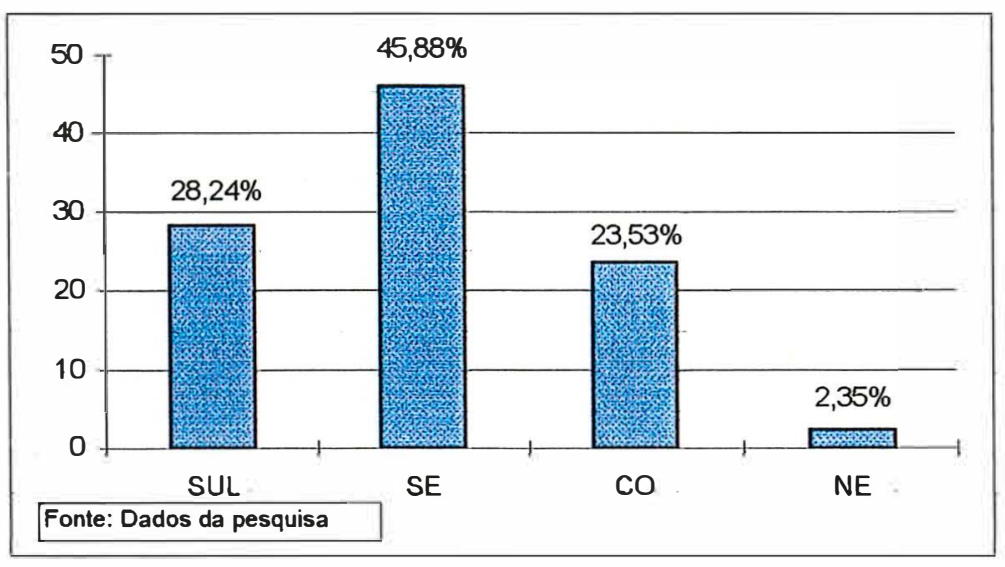

Figura 13. Distribuição geográfica da amostra de produtores rurais, por região (em \%).

Quanto à modalidade de financiamento do produtor, a análise se restringiu àqueles que financiaram suas duas últimas safras através de cooperativas e/ou agroindústrias. Observa-se que, nas duas últimas safras, $43,55 \%$ dos produtores da amostra financiaram suas lavouras de soja através destes agentes, enquanto que apenas $20,73 \%$ dos produtores recorreram a esta opção para o plantio de milho e uma das principais causas desta variação é, seguramente, a maior disponibilidade de recursos oficiais para o milho. Mas o que desperta a atenção é a confrontação dos dados de produtores que indexaram seus financiamentos de soja ao produto com aqueles que fizeram esta mesma opção no caso do milho. Do total de produtores de soja que financiaram seu custeio através daqueles agentes, $44 \%$ indexou o pagamento do financiamento ao produto soja, enquanto que nenhum produtor de milho teve sua dívida indexada ao produto, utilizando índices diversos, na maioria 
das vezes indesejados, como a TR (Taxa Referencial), dólar e TJLP (Taxa de Juros de Longo Prazo) entre outros.

Postula-se que o que viabilizou esta modalidade de financiamento para a soja tenha sido a possibilidade de diminuição dos riscos de oscilações de preços incorridos pelas empresas através de operações de hedge efetuando operações casadas de venda futura na Chicago Board of Trade realizadas no ato do fechamento do empréstimo ao produtor, onde se permitia a fixação do volume de entrega do produto na época da colheita. Outro fator seria a possibilidade de obtenção de créditos com encargos mais vantajosos aos exportadores, vantagem que vem diminuindo com a abertura comercial implementada no país permitindo às empresas nacionais captarem recursos diretamente no exterior. No caso do milho, conforme discutido no item 3.2, as operações de financiamentos de custeio agrícolas pelas empresas seriam dificultadas pelos altos riscos de oscilações de preços incorridos pelos compradores do grão pela impossibilidade de se protegerem em operações de mercados futuros. Sem esta opção, a empresa teria que repassar este risco ao produtor sob a forma de encargos muito elevados inviabilizando a operação, razão pela qual opta-se por indexá-la a índices financeiros, que normalmente acompanham os da captação de recursos pela empresa cuja utilização tem demonstrado, em passado recente, estar sujeita a grandes distorções econômico-financeiras.

5.1.2 Nivel de conhecimento, motivação e opiniões dos produtores

A primeira questão a ser discutida neste item diz respeito ao nivel de conhecimento do produtor quanto aos mercados futuros. Foram elaboradas duas questões, conforme apêndice 5 - questões 8 e 9 , aparentemente redundantes, mas que tinham por objetivo certificar-se de que 0 produtor realmente conhecia os mercados futuros e seus mecanismos básicos, como as operações de hedge. Portanto, foram considerados como conhecedores do 
mercado futuro somente aqueles que assinalaram afirmativamente às duas questões. O resultado obtido foi que 44 ou $51,16 \%$ dos produtores da amostra assumiram conhecer este mecanismo, porcentagem baixa, principalmente se considerado o perfil da população estudada, produtores com grande acesso a informação. Tentou-se inferir se o tamanho da área, ou o porte do produtor, influenciaria no nível de conhecimento do produtor e, para tanto, foi utilizado um modelo de regressão logística, adequado para variáveis binárias, conforme descrito a seguir:

- Supostos estatísticos e metodologia:

Considerou-se que, na população:

$Y_{\mathrm{j}}$ : Variável aleatória que representa conhecimento do mercado futuro, no estrato j, e

$Y_{j}=1: 0$ produtor tem conhecimento do mercado futuro, no estrato $j$.

0 : O produtor não tem conhecimento do mercado futuro, no estrato $\mathrm{j}$.

$Y_{j}$ : Variável dependente binária com distribuição de Bernoulli, tal que:

$P\left(Y_{j}=1\right)=\pi_{j}, e$

$P\left(Y_{j}=0\right)=1-\pi_{j}$.

$\pi_{\mathrm{j}}$ : Probabilidade de "sucesso" ou a probabilidade de que o produtor tenha conhecimento do mercado futuro, no estrato $\mathrm{j}$.

$\bar{X}_{j}:$ Área média por estrato (onde o estrato está em função da área); variável explanatória.

- Postulou-se que:

a) A probabilidade de "sucesso" é uma função de $\bar{X}_{j}$, ou da área média, por estrato, segundo a relação (função logística):

$$
\pi_{j}=\frac{e^{\mathfrak{I}_{0}+I_{1} \bar{x}_{j}}}{1+e^{\mathfrak{I}_{0}+I_{1} \bar{x}_{i}}}
$$


O modelo logístico é amplamente utilizado para dados com distribuição binomial, como no presente caso. Pode-se, de modo a simplificar o trabalho estatístico, fazer a transformação para função chamada "logito", fazendo-se uma regressão em $\ln \left[\pi_{\mathrm{j}} /\left(1-\pi_{\mathrm{j}}\right)\right]$. Assim:

$$
\ln \left[\pi_{\mathrm{j}} /\left(1-\pi_{\mathrm{j}}\right)\right]=\beta_{0}+\beta_{1} \bar{X}_{\mathrm{j}} \quad \text { (Função logito) }
$$

Após 0 ajuste será de interesse testar a hipótese:

$H_{0}: \beta_{1}=0$

$H_{A}: \beta_{1} \neq 0$

A partir da amostra obteve-se, então, a seguinte tabela:

\begin{tabular}{lllllr}
\hline $\begin{array}{c}\text { Estrato de } \\
\text { área (ha) }\end{array}$ & $\mathrm{j}$ & $\mathrm{n}_{\mathrm{j}}$ & $\mathrm{m}_{\mathrm{j}}$ & $\mathrm{p}_{\mathrm{j}}$ & $\overline{\mathrm{X}}_{\mathrm{j}}$ \\
\hline$(0,100]$ & 1 & 18 & 6 & 0,33 & 42,79 \\
$(100,200]$ & 2 & 11 & 5 & 0,45 & 158,5 \\
$(200,500]$ & 3 & 17 & 9 & 0,53 & 348,1 \\
$(500,1.500]$ & 4 & 14 & 8 & 0,57 & $1.142,96$ \\
$(1.500,2.500]$ & 5 & 11 & 7 & 0,64 & $2.006,82$ \\
$>2.500$ & 6 & 13 & 9 & 0,69 & $5.328,11$ \\
\hline onde, & & & & &
\end{tabular}

$\mathrm{n}_{\mathrm{j}}$ : Número de produtores, no estrato $\mathrm{j}$.

$m_{\mathrm{j}}$ : Número de produtores, no estrato $\mathrm{j}$, que tem conhecimento de mercados futuros.

$\hat{\pi}_{j}=p_{j}=m_{j} / n_{j}$ : Proporção de produtores, no estrato $j$, com conhecimento de mercados futuros.

Desta forma, foi feito o ajuste com os dados transformados, considerando In $\left[p_{j} /\left(1-p_{j}\right)\right]$ como variável dependente e usando o pacote estatístico GLIM.

- Ajuste do modelo:

$\hat{\beta}_{0}=-1,767$

$$
\hat{\beta}_{1}=0,3036 \ln \left(\bar{X}_{j}\right)
$$

Desvio Padrão $\left(\hat{\beta}_{0}\right)=0,8841$

$\operatorname{Cov}\left(\hat{\beta}_{0}, \hat{\beta}_{1}\right)=-0,1194$

Desvio Padrão $\left(\hat{\beta}_{1}\right)=0,1397$ 


$$
\begin{aligned}
& \hat{\pi}_{j}=\frac{e^{-1,767+0,3036 \ln \left(\hat{x}_{j}\right)}}{1+e^{-1,767+0,3036 \ln \left(\dot{x}_{j}\right)}} \\
& \ln \left[\hat{\pi}_{j} /\left(1-\hat{\pi}_{j}\right)\right]=-1,767+0,3036 \ln \left(\bar{X}_{j}\right)
\end{aligned}
$$

- Teste de hipótese:

Ho: $\beta 1=0$, ou a variável $\bar{X}_{j}$ não "explica" o conhecimento dos produtores. Assim, de posse dos resultados obtidos, pode-se conduzir a análise de variância (ANOVA) da regressão:

\begin{tabular}{lrrll}
\hline \multicolumn{1}{c}{ C.V. } & G.L. & S.Q. & Q.M. & F \\
\hline Regressão & 1 & 4,98733 & 4,98733 & 200,13 \\
Resíduo & 4 & 0,09967 & 0,02492 & \\
Total & 5 & 5,0870 & & \\
\hline
\end{tabular}

Ao nivel de significância de $5 \%$ e para 1 e 4 graus de liberdade, o valor de $\mathrm{F}$ calculado é de 200,13 , maior que o valor crítico, de 7,71 , portanto rejeitase $H_{0}: \beta_{1}=0$, ou aceita-se que o tamanho da propriedade, ou o porte do produtor, na população considerada influenciaria o nivel de conhecimento do produtor quanto aos mecanismos de operação de mercados futuros. De fato, observando-se a figura 14 que mede o grau de conhecimento do produtor em função dos diferentes estratos de área pode-se detectar uma relação direta entre estas duas variáveis, conforme o resultado do modelo proposto.

Outra questão analisada no presente estudo diz respeito à estratégia esperada do produtor e sua resistência em atuar nestes mercados (apêndice 5, questão 10). Considerou-se, para efeito desta análise e das seguintes, apenas as 44 respostas dos produtores que afirmavam conhecer os mecanismos de mercados futuros na questão anterior. Nesta questão foi perguntado ao produtor se, havendo um mercado futuro de milho no Brasil líquido e transparente, cujo preço futuro na colheita estivesse acima da média histórica 
de sua região, qual seria sua atitude no período que precedesse o plantio. Verificou-se que a grande maioria, 84,09\%, optaria por vender uma parte da produção na Bolsa de Futuros contra 9,09\% que não venderia nada e 6,82\% que venderia toda a produção esperada. Pode-se depreender que o nível de resistência dos produtores seria baixo se ele se sentisse seguro quanto à transparência e liqüidez deste mercado. As razões assumidas para os diferentes tipos de comportamento estão enumeradas na figura 15.

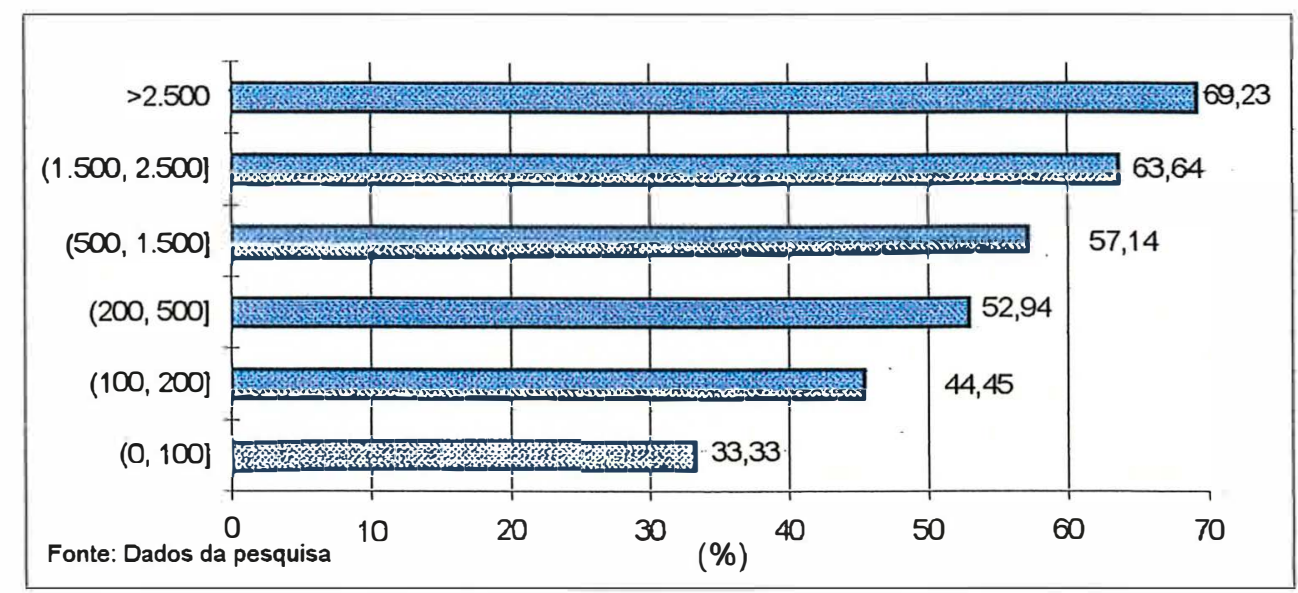

Figura 14. Nivel de conhecimento do produtor (em \%) quanto aos mercados futuros, por estrato de área (em ha) de milho elou soja.

Pode-se verificar que quase $75 \%$ das respostas que visam a justificar a venda de uma parte da produção, ou $64 \%$ de todas as respostas à questão, dizem respeito à proteção de preços do produto e de crédito, que são as três primeiras: garantir preços médios, assegurar as despesas de custeio e garantir as dívidas assumidas junto a bancos e cooperativas. Denota-se aí a compreensão dos produtores quanto aos objetivos do hedge e a sua preocupação quanto ao risco da atividade causado pela estacionalidade da produção. 


\begin{tabular}{|c|c|c|}
\hline VENDERIA TODA A SAFRA & total & $(\%)$ \\
\hline O LUCRO DEVE SE REALIZAR NA ADMINISTRAÇĀO DE CUSTOS & 1 & 33,33 \\
\hline ALTO RISCO DE QUEDA DO PREÇO PELA INSTABILIDADE DA ECONOMIA & 1 & 33,33 \\
\hline ALTO CUSTO DE ARMAZENAMENTO & 1 & 33,33 \\
\hline \multicolumn{3}{|l|}{ VENDERIA PARTE DA SAFRA } \\
\hline GARANTIR PREÇO MEDIO & 20 & 46,51 \\
\hline ASSEGURAR AS DESPESAS DE CUSTEIO (CUSTO DE PRODUÇĀO) & 8 & 18,60 \\
\hline GARANTIR AS DIVIDAS ASSUMIDAS JUNTO A BANCOS E COOPERATIVAS & 4 & 9,30 \\
\hline NORMALMENTE O MILHO EM MAIO ESTÁ ABAIXO DO PREÇO MINIMO & 3 & 6,98 \\
\hline \multicolumn{3}{|l|}{ ATRAVÉS DE CONTROLE DE CUSTOS PODE-SE VENDER QUANDO SE } \\
\hline ATINGIR UM LUCRO MINIMO ESPERADO & 2 & 4,65 \\
\hline EM RAZĀO DOS RISCOS CLIMÁTICOS EXISTENTES NA SAFRA & 2 & 4,65 \\
\hline OS PREÇOS NORMALMENTE ESTÃO MAIS ALTOS DURANTE A ENTRESSAFRA & 2 & 4,65 \\
\hline VENDER APENAS PARTE ATÉ ADQUIRIR TOTAL CONFIANÇA NO SISTEMA & 1 & 2,33 \\
\hline PARA "SENTIR" O MERCADO & 1 & 2,33 \\
\hline \multicolumn{3}{|l|}{ NÃO VENDERIA } \\
\hline COM CERTEZA OS PREÇOS ESTARIAM MELHORES NA ENTRESSAFRA & 2 & 50,00 \\
\hline O MILHO É PARA CONSUMO PRÓPRIO & 1 & 25,00 \\
\hline PREFERIVEL ESPECULAR COM O MILHO ÀS APLICAÇŌES FINANCEIRAS & 1 & 25,00 \\
\hline
\end{tabular}

Fonte: Dados da pesquisa

Figura 15 . Justificativas dos produtores para estratégia de venda antecipada de milho no mercado futuro.

Outra questão refere-se aos fatores que, na opinião dos respondentes, seriam responsáveis pelas maiores dificuldades para o desenvolvimento de um mercado futuro de milho no Brasil (apêndice 5 , questão 10). Observou-se que as maiores causas seriam, pela ordem:

- constantes intervenções governamentais;

- desconhecimento dos produtores quanto às vantagens deste instrumento;

- falta de acesso a corretores de mercados futuros de sua confiança e

- desuniformidade fiscal (Anexo A).

Percebe-se que, duas das questões referem-se a questões de ordem estrutural e duas de ordem cultural. Assim, as constantes intervenções do governo impedem que os preços flutuem segundo as forças de mercado e a 
desuniformidade fiscal gera distorções regionais nos preços. Quanto ao desconhecimento do produtor e a falta de acesso a corretores denotam a falta de aproximação e de afinidade entre os elos desta cadeia agroindustrial.

As sugestões apontadas pelos produtores para o desenvolvimento de um mercado futuro de milho no Brasil podem ser observadas na figura 16 . Percebe-se, na maior parte delas, preocupação quanto ao trabalho de esclarecimento dos mecanismos deste mercado junto ao meio produtor, como maior divulgação do sistema, trabalho de conscientização das suas vantagens, treinamento de pessoal nas cooperativas para que possa auxiliar na decisão do produtor e "desmistificação" dos mercados futuros. Destacam-se, também, sugestões no sentido de mudanças estruturais como menor intervenção do governo, reforma tributária uniformizando cobrança de impostos'e a melhoria de transportes e armazenagem.

Quanto às sugestões de operacionalização das Bolsas e corretoras distinguem-se as seguintes: criação e divulgação de mecanismos que evidenciem confiança e transparência no sistema, formulação de instrumentos que tornem o sistema prático para a utlilização do produtor, como maior difusão de sistemas on line e treinamento de corretores de mercados futuros para que "falem a língua" do produtor e, finalmente, credenciamento de Armazéns Gerais confiáveis para o caso de efetiva entrega física do produto.

\subsection{Traders de Cooperativas e Agroindústrias}

\subsubsection{Perfil dos traders e das empresas}

De um total de 368 questionários enviados respectivamente a 179 cooperativas, 173 indústrias de rações e 16 indústrias moageiras, obteve-se um retorno de 71 respostas ou 19,29\% do total. Os respondentes tinham, na média, 10,8 anos de experiência profissional, com desvio padrão de 7,62 anos. $O$ porte médio das empresas pesquisadas foi considerado grande em função 
dos volumes médios anuais de grãos comercializados nas últimas três safras que foi 52.000 t para o milho e de 69.600 t para a soja, porém com alta variabilidade, apresentando desvio padrão de 60.269 t e 94.080 t, respectivamente.

\begin{tabular}{lcc}
\hline SUGESTÓES & total & $(\%)$ \\
\hline MAIOR DIVULGAÇAOO DO SISTEMA JUNTO AO MEIO RURAL & 6 & 17,65 \\
MENOR INTERVENÇÃO DO GOVERNO NO MERCADO & 4 & 11,76 \\
CRIAÇÃO DE MECANISMOS QUE GEREM CONFIANÇA NO SISTEMA & 3 & 8,82 \\
MECANISMOS QUE GARANTAM TRANSPARÊNCIA NO MERCADO & 3 & 8,82 \\
UNIFICAÇÃO DE IMPOSTOS & 2 & 5,88 \\
CRIAÇÃO DE MECANISMOS QUE TORNEM O SISTEMA PRÁTICO AO PRODUTOR & 2 & 5,88 \\
TRABALHO DE CONSCIENTIZAÇÃO DO PRODUTOR & 2 & 5,88 \\
OBTENÇÃO DE LIQÜIDEZ NO MERCADO & 2 & 5,88 \\
CREDENCIAMENTO DE ARMAZÉNS CONFIÁVEIS & 1 & 2,94 \\
FACILIDADE DE CRÉDITO PARA CONSTRUÇÃO DE ARMAZĖNS NAS PROPRIEDADES & 1 & 2,94 \\
TREINAMENTO DE PESSOAL NAS COOPERATIVAS PARA ORIENTAR O PRODUTOR & 1 & 2,94 \\
SISTEMA DE INFORMAÇÕES ON-LINE EM COOPERATIVAS & 1 & 2,94 \\
FORMAÇÃO DE ESTOQUES PELO GOVERNO ATRAVÉS DE MERCADOS FUTUROS & 1 & 2,94 \\
PARTICIPAÇÃO ATIVA DE COOPERATIVAS NO PROCESSO DE INTERMEDIAÇÃOENTRE & & \\
PRODUTORES E CORRETORAS & 1 & 2,94 \\
MELHORIA EM INFRA-ESTRUTURA DE TRANSPORTES E ARMAZENAGEM & 1 & 2,94 \\
TREINAMENTO DE CORRETORES PARA QUE "FALEM A LINGUA" DO PRODUTOR & 1 & 2,94 \\
DESMISTIFICAÇÃO DOS MERCADOS FUTUROS JUNTO AO PRODUTOR & 1 & 2,94 \\
É UMA FORMA DE SE ACABAR COM A CARTELIZAÇÃO DE PREÇOS EM CERTAS REGIÕES & 1 & 2,94 \\
\hline
\end{tabular}

Fonte: Dados da pesquisa

Figura 16. Sugestões apontadas pelos produtores rurais para o desenvolvimento de um mercado futuro de milho no Brasil.

Pouco mais da metade das empresas afirmou prover os produtores de recursos financeiros ou insumos para o plantio de soja e milho, porém nota-se diferença expressiva quanto à forma de indexação destes financiamentos (figura 17). 
\begin{tabular}{|l|c|c|}
\hline & milho & soja \\
\hline \% de empresas que financiam o produtor & 53,52 & 52,11 \\
\hline \% das empresas que indexam o financiamento ao produto & 39,47 & 75,68 \\
\hline
\end{tabular}

Fonte: Dados da pesquisa

Figura 17. Porcentagem de empresas que financiam os produtores e daquelas que indexam seus financiamentos ao produto financiado, por cultura.

Foi realizado teste para se detectar se a diferença entre a porcentagem dos financiamentos de empresas que adotavam a equivalência-produto para milho e a porcentagem daqueles indexados à soja seria significativa do ponto de vista estatístico. Utilizou-se, para tanto, o teste para proporções explicado a seguir:

- Supostos estatísticos e metodologia:

- Hipótese de interesse:

$H_{0}: p_{1}=p_{2}$

$H_{A}: p_{1}>p_{2}$

$\hat{p}_{1}=X_{1} / n_{1}$ : proporção de empresas que indexam seus financiamentos à soja, na amostra.

$\hat{p}_{2}=X_{2} / n_{2}$ : proporção de empresas que indexam seus financiamentos ao milho.

Adotou-se 0 critério de se testar, como hipótese alternativa, $p_{1}>p_{2}$ pois se esperava uma maior proporção de indexação para o caso da soja, conforme discutido anteriormente no item que trata sobre as relações contratuais na cadeia do milho (2.2).

$n_{1}$ : Número de empresas da amostra que financiam produtores de soja $=37$

$\mathrm{n}_{2}$ : Número de empresas da empresas que financiam produtores de milho $=38$ 
$X_{1}$ : Número de empresas que utilizam a equivalência-produto para a soja $=28$

$X_{2}$ : Número de empresas que utilizam a equivalência produto para o milho $=15$ milho, na amostra.

Pressupõe-se que:

$X_{1} \sim N\left(n_{1} p_{1}, n_{1} p_{1} q_{1}\right)$ e, de forma análoga:

$X_{2} \sim N\left(n_{2} p_{2}, n_{2} p_{2} q_{2}\right)$.

$\hat{p}_{1} \sim N\left(p_{1}, p_{1} q_{1} / n_{1}\right)$

$\hat{p}_{2} \sim N\left(p_{2}, p_{2} q_{2} / n_{2}\right)$, então:

$\hat{p}_{1}-\hat{p}_{2} \sim N\left(p_{1}-p_{2},\left(p_{1} q_{1}\right) / n_{1}+\left(p_{2} q_{2}\right) / n_{2}\right)$

Portanto, sob $\mathrm{H}_{0}$ :

$$
Z=\frac{\hat{p}_{1}-\hat{p}_{2}-\left(p_{1} p_{2}\right)}{\frac{\mathcal{V} p_{1} q_{1}}{n_{1}}+\frac{p_{2} q_{2}}{n_{2}}} \sim N(0,1)
$$

Como $p_{1}$ e $p_{2}$ são desconhecidos e, em $H_{0}: p_{1}=p_{2}=p$, o estimador apropriado de $p$ é:

$$
\begin{aligned}
& \hat{p}=\frac{x_{1}+x_{2}=n_{2} \hat{q}_{1}+n_{2} \hat{p}_{2}}{n_{1}+n_{2}} \\
& \text { onde } \hat{q}=1-\hat{p}
\end{aligned}
$$

Neste caso, sob $\mathrm{H}_{0}$ :

$$
\operatorname{var}\left(\hat{p}_{1}-\hat{p}_{2}\right)=\hat{p} \hat{q} \frac{\left(n_{1}+n_{2}\right)}{n_{1} n_{2}}
$$


Finalmente, fazendo-se a correção por continuidade, ou seja, subtraindo 0,5 do numerador da fração maior e adicionando 0,5 no numerador da fração menor, tem-se que:

$$
Z=\frac{\frac{x_{1}-0,5}{n_{1}}-\frac{x_{2}+0,5}{n_{2}}}{\sqrt{\hat{p} \hat{q} \frac{\left(n_{1}+n_{2}\right)}{n_{1} n_{2}}}} \sim N(0,1)
$$

- Regra de decisão:

Se $Z>1,645 \Rightarrow$ Rejeitar $\mathrm{H}_{0}, \operatorname{com} \alpha=5 \%$.

- Resultados:

$$
\begin{array}{ll}
\hat{p}=(28+15) /(37+38)=0,5733 & \hat{q}=1-\hat{p}=0,4267 \\
\hat{p}_{1}=28 / 37=0,7568 ;\left(n_{1}=37\right) & \\
\hat{p}_{2}=15 / 38=0,3947 ;\left(n_{2}=38\right) &
\end{array}
$$

$$
Z=\frac{\frac{28-0,5}{37} \frac{15+0,5}{38}}{\sqrt{0,5733 \times 0,4267\left(\frac{1}{37}+\frac{1}{38}\right)}}=\frac{0,3353}{0,0130}=25,7923
$$

- Decisão

Como $Z>Z_{0}=1,645$, rejeita-se, ao nível de significância de $5 \%$, a hipótese $H_{0}: p_{1}=p_{2}$, em favor de $H_{A}: p_{1}>p_{2}$. No caso, como $p_{1}>p_{2}$, conclui-se que a proporção de financiamentos concedidos pelas cooperativas e agroindústrias indexados à soja é maior que os indexados ao milho.

Esta constatação confirma os resultados esperados de que a possibilidade das empresas financiarem os produtores sob a modalidade de 
equivalência-produto é maior para a soja. Há, no entanto, uma aparente contradição quando se compara estas respostas com as dos produtores, principalmente no tocante à proporção de produtores que indexaram suas dívidas ao produto milho, contraídas junto às agroindústrias e cooperativas. Enquanto na pesquisa conduzida junto aos traders pode-se constatar que quase $40 \%$ de suas empresas oferecem financiamentos para custeio de milho através do sistema de equivalência-produto, a totalidade da amostra de produtores afirmou não ter tido acesso a esta modalidade. Supondo-se que houve plena compreensão da forma pela qual a questão foi elaborada, pode-se tentar explicar esta diferença de duas formas distintas: ou os financiamentos foram oferecidos para outro perfil de produtores não atingido pela presente pesquisa como, por exemplo, para mini e pequenos produtores, ou esta modalidade, apesar de oferecida pelas empresas, não despertou interesse entre os produtores para o caso do milho, diferentemente da soja, onde $44 \%$ dos produtores afirmam ter financiado sua produção, indexando seus débitos a este produto. Neste caso, pode-se sugerir que a principal causa à resistência estaria relacionada aos altos encargos embutidos nesta operação, confirmando discussões anteriores sobre repasse de riscos pelas empresas para os produtores na falta de possibilidade de hedge para as aquisições antecipadas de milho.

Finalmente, observa-se, também, que a experiência das empresas em atuar em mercados futuros é baixa, sendo que apenas 17 delas, ou $24 \%$ do total operam ou já operaram nestes mercados no caso da soja e $4,23 \%$ se utilizaram deste instrumento para operações de café.

\subsubsection{Opiniões e sugestões dos traders}

Foi perguntado também quanto ao potencial de desenvolvimento de mercados futuros da soja e do milho (apêndice 6, questões 10 e 11), classificando-o segundo escala de 1 a 5 , muito pequeno e muito grande, 
respectivamente. Observou-se que 0 milho obteve média de 3,17 e desvio padrão de 1,40, enquanto a soja teve média de 3,80 e desvio padrão de 1,20. Ambos foram, portanto, considerados acima da média com ligeira preferência para a soja. As opiniões favoráveis e desfavoráveis para o desenvolvimento de mercado para as duas culturas foram classificadas por grupos de respostas e as principais para o caso do milho foram, pela ordem:

Opiniões favoráveis:

- permitiria diminuição da oscilação dos preços (23,0\% das respostas);

- atuaria como sinalizador de preços $(19,0 \%)$;

- ofereceria maior segurança ao produtor(14,0\%);

- maior pulverização de produtores e indústrias em relação à soja $(9,5 \%)$;

- grande potencial de crescimento $(9,5 \%)$ e

- diminuição das distorções regionais de preços para pequenos produtores em função do maior fluxo de informação $(4,8 \%)$.

Percebe-se que as três principais respostas referem-se à preocupação com a segurança do produtor, enquanto as duas seguintes destacam aspectos estruturais positivos da cadeia que a qualificam para o desenvolvimento de um mercado futuro. A última resposta aponta importante papel, de cunho social, que pode ser desenvolvido por estes mercados já que, como discutido em capítulos anteriores, esta cadeia destaca-se pela sua heterogeneidade entre seus produtores e suas conseqüentes distorções regionais.

Quanto às opiniões desfavoráveis destacaram-se as seguintes:

- alta intervenção governamental, através de estoques reguladores e preços mínimos (18,8\% das respostas);

- falta de tradição deste mercado entre os agentes da cadeia do milho $(12,5 \%)$

- falta de conhecimento e divulgação entre os agentes (12,5\%).

Nota-se que, assim como no caso dos produtores, os maiores entraves ao desenvolvimento do mercado futuro de milho no Brasil na opinião dos 
traders estariam relacionados com a alta intervenção governamental e com aspectos culturais junto aos potenciais hedgers.

Quanto às opiniões destes agentes às assertivas propostas na questão 12 , apêndice 6 obteve-se mais de $50 \%$ de "verdadeiro" e menos de "15\% de "falso" as seguintes afirmações:

- Os mercados futuros podem facilitar financiamento para produtores, com $78,0 \%$ de "verdadeiro" e 6,6\% de "falso".

- A desuniformidade fiscal dificulta o mercado futuro de milho, com $69,0 \%$ de "verdadeiro" e 9,5\% de "falso".

- É necessário a "desmistificação" da figura do especulador para os produtores, com $54,8 \%$ de "verdadeiro" e $14,5 \%$ de "falso" (Anexo B).

Observa-se que o mercado demonstra acreditar que a existência de um mercado futuro pode servir como instrumento de "alavancagem" de recursos para financiamento do produtor, a exemplo do que já ocorre atualmente com a soja e a laranja. Outro ponto importante destacado é a questão da desuniformidade fiscal e, finalmente, a necessidade da melhor divulgação junto aos produtores do funcionamento e operacionalização das Bolsas de Mercados Futuros.

Finalmente, classificou-se e quantificou-se as sugestões apontadas pelos traders para o sucesso dos mercados futuros de milho no Brasil, conforme figura 18. Nota-se, da mesma forma que no caso dos produtores, que o maior número de sugestões referem-se à melhoria do nivel de informação junto ao meio rural e mudanças estruturais a nivel governamental. Quanto aos aspectos estruturais e econômicos destacam-se a revisão tributária, menor intervenção governamental nos mercados agricolas, manutenção do plano de estabilização, incentivo à criação e fortalecimento de instrumentos alternativos de comercialização como CPR e CM-G, eliminação de preços mínimos, diminuição de taxas portuárias e melhoria no sistema de transportes. Quanto ao aspecto institucional sugerem organização de 
palestras e cursos para agentes, envolvimento de líderes dos setores, cooperativas e de bancos, inclusive através de criação de formas de financiar os ajustes diários e, finalmente, criação de câmaras setoriais que realmente sejam representativas dos diversos setores envolvidos.

\begin{tabular}{|c|c|c|}
\hline SUGESTŐES & TOTAL & (\%) \\
\hline MAIOR INFORMAÇAO AO SETOR RURAL & 11 & 29,73 \\
\hline NECESSIDADE DE POLITICA AGRICOLA DE LONGO PRAZO & 4 & 10,81 \\
\hline REVISÃO DA TRIBUTAÇĀO & 3 & 8,11 \\
\hline MENOR INTERVENÇĀO GOVERNAMENTAL & 2 & 5,41 \\
\hline NECESSÁRIO A MANUTENÇĀO DA ESTABILIZAÇĀO ECONÔMICA & 2 & 5,41 \\
\hline ORGANIZAÇĀO DE CURSOSE PALESTRAS PARA OS AGENTES PARTICIPANTES & 2 & 5,41 \\
\hline \multicolumn{3}{|l|}{ IMPORTÂNCIA DE SE CRIAR FORMAS COMPLEMENTARES DE COMERCIALIZAÇĀO } \\
\hline (COMO CPRE CM-G) & 2 & 5,41 \\
\hline MELHORIA NO SISTEMA DE COOPERATIVAS & 1 & 2,70 \\
\hline ELIMINAÇÃO DE PREÇOS MÍNIMOS & 1 & 2,70 \\
\hline CREDENCIAMENTO E CONFIABILIDADE NOS ARMAZÉNS GERAIS & 1 & 2,70 \\
\hline DIMINUIÇÃO DAS TAXAS PORTUÁRIAS & 1 & 2,70 \\
\hline MELHORIA NO SISTEMA DE TRANSPORTES & 1 & 2,70 \\
\hline \multicolumn{3}{|l|}{ CRIAÇÃO DE GRUPOS QUE REPRESENTEM O SETOR PARA PARTICIPAR DA ELABORAÇĀO } \\
\hline E IMPLANTAÇĀO DESTES MERCADOS & 1 & 2,70 \\
\hline MECANISMOS QUE GEREM RECURSOS PARA CUSTEAR OS AJUSTES DIÁRIOS & 1 & 2,70 \\
\hline NECESSIDADE DE MELHORES CONDIÇŌES DE ENSINO NO MEIO RURAL & 1 & 2,70 \\
\hline \multicolumn{3}{|l|}{ ENVOLVIMENTO DE LIDDERES E SINDICATOS RURAIS GERANDO MAIOR CREDIBILIDADE } \\
\hline AO MECANISMO & 1 & 2,70 \\
\hline ENVOLVIMENTO DO BANCODO BRASIL & 1 & 2,70 \\
\hline \multicolumn{3}{|l|}{ ENVOLVIMENTO DE COOPERATIVAS NO AUXÍLIO AOS PRODUTORES NA TOMADA } \\
\hline DE DECISĀO & 1 & 2,70 \\
\hline
\end{tabular}

Fonte: Dados da pesquisa

Figura 18. Sugestões apontadas pelos traders para o desenvolvimento de um mercado futuro de milho no Brasil.

\subsection{Corretores de Mercados Futuros}

5.3.1 Perfil dos corretores e das empresas

De um total de 172 questionários enviados, obteve-se um índice de retorno de $13,95 \%$, ou 24 respostas. Os corretores da amostra contavam com 
uma experiência profissional média de 12,54 anos na atividade apresentando desvio padrão de 11,49 anos. As commodities mais comercializadas nos mercados futuros pelas corretoras da amostra como primeira opção são, pela ordem, taxa de juros, câmbio e índice Bovespa. A soja aparece duas vezes em quinto lugar, 3 vezes em sexto e 2 vezes em sétimo lugar, sendo, portanto, comercializada por 7 corretoras, ou $29 \%$ da amostra. O café é comercializado por $45 \%$ das corretoras da amostra.

\subsubsection{Opiniões e sugestões dos corretores}

Perguntados sobre o potencial de mercados futuros agrícolas, classificando-o segundo escala de 1 a 5 , muito pequeno e muito grande, respectivamente, apurou-se uma média de 3,86 com desvio padrão de 1,42, isto é, grande potencial. Foram, então, ordenadas e destacadas as principais opiniões favoráveis e desfavoráveis para esta classificação. As três opiniões mais apontadas foram:

- o país tem grande vocação agrícola com grande potencial de aumento de produção e consumo ( $52,6 \%$ das respostas);

- é um importante instrumento de alavancagem de recursos $(15,8 \%)$ e

- gera diminuição de riscos para produtores e compradores $(10,5 \%)$.

Assim como o segmento de traders, pode-se perceber que os operadores de mercados futuros acreditam que a existência de mercados futuros agrícolas favoreceria maior afluxo de capitais para o financiamento de produtores nos mercados físicos.

Quanto às opiniões desfavoráveis, destacam-se:

- falta de cultura entre produtores (33,3\% das respostas);

- inexistência de internacionalização $(20,0 \%)$ e

- falta de política agrícola definida e intervenções constantes $(13,3 \%)$. 
Além dos aspectos culturais e da política intervencionista do governo já abordados pelos agentes anteriores, destaca-se, também, a questão da falta de internacionalização das Bolsas como fator que dificultaria o desenvolvimento dos mercados futuros agrícolas no país.

Quanto às commodities agrícolas com maior potencial foram consideradas, pela ordem, soja, seguida pelo milho e açúcar empatados, suco de laranja, algodão, frango e suíno.

As principais justificativas para o potencial do mercado futuro de milho no Brasil foram, pela ordem:

- volume de produção e importância econômica (36,4\% das respostas);

- grande número de participantes no mercado $(27,3 \%)$;

- diversidade de indústrias consumidoras $(18,2 \%)$;

- alta volatilidade dos preços $(9,1 \%)$ e

- possibilidade de aumentos de produtividades $(9,1 \%)$.

Quanto às razões da falta de liqüidez dos antigos contratos futuros da soja no Brasil, obteve-se como respostas principais as seguintes:

- pequena difusão deste instrumento no meio produtor (16,2\% das respostas);

- excesso de intervenção governamental $(10,8 \%)$;

- deficiência na formulação do contrato, como por exemplo, a dificuldade da entrega física $(8,1 \%)$;

- concorrência com Bolsas internacionais $(8,1 \%)$ e

- descrença elou falta de interesse dos operadores por estes contratos $(5,4 \%)$.

Em relação às possiveis dificuldades para implantação de um mercado futuro de milho no Brasil (apêndice 7, questão 8), foram apontadas as afirmações, com mais de $50 \%$ de "verdadeiro" e menos de $30 \%$ de "falso" na figura 19 (obtida a partir do Anexo $\mathrm{C}$ ). 


\begin{tabular}{|l|r|r|}
\hline & $\mathrm{V}$ & \multicolumn{1}{|c|}{$\mathrm{F}$} \\
\hline DESCONFIANÇA DO PRODUTOR E/OU FALTA DE DIVULGAÇĀO & 81,82 & 4,55 \\
\hline DESUNIFORMIDADE FISCAL & 60,87 & 4,35 \\
\hline SONEGAÇĀO NO MERCADO FISICO EM FUNÇĀO DA ALTA TAXAÇĀO & 59,09 & 4,55 \\
\hline FALTA DE TRADIÇĀO DE MERCADOS FUTUROS & 59,09 & 18,18 \\
\hline DESCONHECIMENTO DOS CORRETORES DO MERCADO FISICO & 54,55 & 27,27 \\
\hline PREFERENCIA POR BOLSAS INTERNACIONAIS (ALTA CORRELAÇĀO) & 52,17 & 8,70 \\
\hline
\end{tabular}

Fonte: Dados da pesquisa

Figura 19. Principais razões das possíveis dificuldades do desenvolvimento de um mercado futuro de milho no Brasil, apontadas pelos corretores.

Observa-se que dentre as seis razões principais para as dificuldades para a implantação do mercado de milho, na opinião dos produtores, duas estariam ligadas a questões tributárias e três de ordem cultural, seja do produtor, seja dos corretores ou da própria falta de tradição do mercado para esta cadeia agropecuária. A sexta refere-se, equivocadamente, à suposta preferência por Bolsas internacionais por parte dos hedgers em função de sua alta correlação, o que já foi discutido no item 3.2 do presente trabalho e demonstrado que esta correlação, no caso do milho, seria muito baixa para fins de proteção de oscilações de preços.

As sugestões dos corretores para implantação deste mercado no Brasil estão descritas na figura 20. A questão relacionada à informação foi a que apresentou maior número de sugestões, como difusão de conceitos de mercados futuros aos diversos segmentos e por commodity, criação de programas e disciplinas sobre mercados futuros nas universidades, aproximação do meio rural com estes mercados, inclusive no sentido de "desmistificar" o papel dos especuladores nas Bolsas de Futuros e divulgação através da mídia, cursos e palestras. Grande número de sugestões dizem respeito à operacionalização dos contratos, como possibilidade de liqüidação financeira e através de índices referenciais, criação de mecanismos de compensação junto aos bancos para cooperativas e outras empresas rurais, 
regras claras de padronização do produto para o caso de entrega física e criação de mecanismos de financiamentos das margens para produtores.

\begin{tabular}{|c|c|c|}
\hline SUGESTŌES & TOTAL & (\%) \\
\hline MAIOR DIFUSÁO DE CONCEITO DE MERCADOS FUTUROS POR SETOR DE COMMODITY & 7 & 33,33 \\
\hline \multicolumn{3}{|l|}{ CRIAÇĀO NAS UNIVERSIDADES DE PROGRAMAS EDUCATIVOS E DISCIPLINAS SOBRE } \\
\hline MERCADOS FUTUROS & 2 & 9,52 \\
\hline POSSIBILIDADE DE LIQUIDAÇĀO FINANCEIRA & 1 & 4,76 \\
\hline LIQUIDAÇÃO POR INNDICES REFERENCIAIS & 1 & 4,76 \\
\hline PROPORCIONAR FAMILIARIDADE E CONFIABILIDADE AOS PRODUTORES & 1 & 4,76 \\
\hline CRIAÇĀO DE MECANISMOS DE COMPENSAÇẢO JUNTO AOS BANCOS PARA AS & & 0,00 \\
\hline COOPERATIVAS E OUTRAS EMPRESAS AGRICOLAS & 1 & 4,76 \\
\hline \multicolumn{3}{|l|}{ CRIAÇĀO DE PROGRAMAS DE DIVULGAÇÃO E COMUNICAÇĀO PERMANENTE AOS } \\
\hline DIVERSOS AGENTES ENVOLVIDOS & 1 & 4,76 \\
\hline DEFINIÇĀO DE REGRAS DE PADRONIZAÇĀO DO PRODUTO & 1 & 4,76 \\
\hline \multicolumn{3}{|l|}{ ESTIMULAR PRIMEIRAMENTE GRANDES CONSUMIDORES, INTERMEDIÁRIOS, COOPERATIVA } \\
\hline DEIXANDO OS PRODUTORES RURAIS PARA UMA PRÓXIMA ETAPA & 1 & 4,76 \\
\hline DESMISTIFICAÇĀO DO PAPEL DO ESPECULADOR NAS BOLSAS & 1 & 4,76 \\
\hline MAIOR INCENTIVO DO GOVERNO PARA O SETOR DE SERVIÇOS & 1 & 4,76 \\
\hline MAIOR DIVULGAÇĀOATRAVÉS DA MIDIA, CURSOS E PALESTRAS & 1 & 4,76 \\
\hline POSSIBILIDADE DE FINANCIAMENTO DAS MARGENS PARA PRODUTORES & 1 & 4,76 \\
\hline MAIOR DIVULGAÇĀO PRINCIPALMENTE JUNTO A COOPERATIVAS & 1 & 4,76 \\
\hline
\end{tabular}

Fonte: Dados da pesquisa

Figura 20. Sugestões apontadas pelos corretores de mercados futuros para o desenvolvimento de um mercado futuro de milho no Brasil. 
6 CONCLUSÕES 


\section{CONCLUSÕES}

Os resultados da presente investigação permitem as seguintes conclusões:

1) O nivel de conhecimento dos produtores quantos aos mecanismos dos mercados futuros mostrou-se baixo (51\%), principalmente considerando-se que a população considerada era formada por produtores com mais acesso à informação. Pode-se comprovar uma relação direta entre o porte do produtor e o seu nivel de conhecimento. Os produtores se mostraram dispostos a vender parte de sua produção caso houvesse um mercado futuro de milho com transparência e liqüidez.

2) Observou-se que as Bolsas de Futuros têm exercido papel importante como instrumento auxiliar na alavancagem de recursos de financiamento para outras culturas, como a soja, atuando como instrumento de proteção para o setor industrial e exportador e importante referencial de preço para o produtor. Apesar de quase $40 \%$ das indústrias e cooperativas afirmarem que indexam seu produto ao milho, contra $75 \%$ que o fazem no caso da soja, detectou-se que nenhum produtor entrevistado recorreu a esta modalidade de financiamento indexada ao milho enquanto que $44 \%$ utilizou a equivalênciaproduto para a soja. Conclui-se que, ou os financiamentos foram oferecidos para outro perfil de produtores não atingido pela presente pesquisa ou sua não utilização poderia estar relacionada aos altos encargos embutidos nesta operação como forma de repasse de riscos pelas empresas pela falta de possibilidade de hedge de preços na aquisição antecipada do milho. 
3) Os corretores de mercados futuros acreditam no potencial de desenvolvimento dos mercados futuros agrícolas e o milho é considerado por estes agentes como a segunda commodity agrícola potencial ficando atrás da soja e junto com o açúcar. No entanto, cerca de $54 \%$ afirmam que, entre as maiores dificuldades para sua implantação, destaca-se o desconhecimento do mercado físico de milho por parte dos corretores.

4) Assim como os produtores e corretores, os traders das cooperativas e agroindústrias acreditam no potencial do mercado futuro de milho no Brasil (considerado de médio a grande). Os principais fatores que determinam esta condição, segundo os diversos agentes, são o expressivo volume financeiro e físico movimentado pelo setor, com grande possibilidade de crescimento, pulverização e diversificação dos mercados de produtores e agroindustrial, alta volatilidade dos preços e a recente estabilização econômica.

5) No que diz respeito aos maiores benefícios e vantagens deste mercado, apontadas pelos três segmentos, destacam-se a possibilidade de menores riscos a produtores e compradores do grão funcionando como proteção e sinalização de preços, a diminuição da oscilação de preços ao longo do ano, maiores dificuldades de cartelização na fixação de preços e a possibilidade de alavancagem de recursos para o financiamento de safras agrícolas.

6) Quanto às maiores restrições a estes mercados, apontadas pelos três segmentos, destacam-se o desconhecimento dos mecanismos de mercados futuros e hedge junto ao meio produtor assim como dos corretores quanto ao mercado físico, falta de integração e afinidade entre o meio rural e o setor financeiro, constantes intervenções governamentais no mercado e a desuniformidade fiscal e elevada carga tributária. 
7) Finalmente, as sugestões apresentadas com maior freqüência entre os agentes foram de ordem educacional, estrutural e operacional.

Quanto às sugestões de ordem educacional, destacam-se:

- Ampla divulgação e esclarecimentos do funcionamento destes mercados junto ao meio rural através de desenvolvimento de cursos e palestras, preferencialmente com a participação das corretoras de mercados futuros como forma de gerar integração entre os segmentos;

- Criação de programas e disciplinas sobre mercados futuros nas Universidades em cursos de Agronomia, Administração de Empresas, Economia e afins;

- Treinamento e profissionalização de pessoal das cooperativas para que possam atuar em mercados futuros inclusive auxiliando e orientando a decisão do produtor;

- Analogamente, treinamento de corretores de mercados futuros para que desenvolvam conhecimentos das cadeias agroindustriais, seus agentes e relações contratuais, mecanismos de formação e comportamento de preços, formas de comercialização nos mercados físicos e políticas governamentais para o setor;

- Enfim, medidas que possibilitem a abertura de canais de comunicação entre empresas do agribusiness e o sistema financeiro, preferencialmente com o envolvimento de líderes dos diversos setores, do governo, de instituições como as Bolsas e Bancos e Universidades.

Do ponto de vista estrutural, físico e econômico, sugere-se:

- Menor intervenção governamental nos mercados, atuando apenas de forma regulatória e com regras claras e de longo prazo; 
- Reforma fiscal e tributária simplificando e uniformizando o sistema de impostos existente;

- Estímulo à criação e desenvolvimento de formas alternativas e complementares de financiamentos e comercialização como a CPR e CM-G e incentivos ao fortalecimento de fundos de commodities que efetivamente canalizem recursos para o setor agrícola;

- Melhoria na infra-estrutura de armazenagem, escoamento e portos, promovendo a integração entre rodovias, ferrovias e hidrovias e

- Incentivo à especialização no campo através do zoneamento agrícola.

Quanto à operacionalização do sistema propõe-se:

- Elaboração de contratos que incentivem a liqüidação financeira e através de indices referenciais;

- Criação de mecanismos de compensação junto a bancos para cooperativas e empresas rurais e sistemas de financiamento para margens e ajustes diários, através de crédito rotativo.

- No caso da opção da liqüidação por entrega física, credenciamento de armazéns gerais confiáveis e eficientes em regiões com alta concentração de produção elou consumo e elaboração de regras claras de padronização

- Criação de mecanismos que facilitem o acompanhamento diário e on line da evolução dos mercados no meio rural;

- Criação de câmaras setoriais que realmente sejam representativas dos diversos setores envolvidos e

- Fortalecimento da imagem das Bolsas de Futuros para que transmitam a confiança e transparência necessárias ao sistema. 
7 ANEXOS 
Anexo A Fatores que geram as maiores dificuldades para a implantação de um mercado futuro de milho no Brasil em \%, segundo os produtores rurais.

\begin{tabular}{|l|l|r|}
\hline $10^{\circ}$ & CONSTANTES INTERVENÇŐES GOVERNAMENTAIS & 63,89 \\
\hline $2^{\circ}$ & DESCONHECIMENTO DO PRODUTOR QUANTO AS & \\
\hline & VANTAGENS DESTE TIPO DE MERCADO & 62,50 \\
\hline $3^{\circ}$ & FALTA DE ACESSO A CORRETORES DE MERCADOS & \\
\hline & FUTUROS DE SUA CONFIANÇA & 55,56 \\
\hline $4^{\circ}$ & DESUNIFORMIDADE FISCAL & 37,50 \\
\hline $5^{\circ}$ & EXISTENCIA DE ESPECULADORES DA A IDEIA DE QUE & \\
\hline & ESTE TIPO DE OPERAÇÄO ENVOLVE GRANDES RISCOS & 30,56 \\
\hline $6^{\circ}$ & NECESSIDADE DE PAGAMENTO DE AJUSTES DIARIOS & 29,17 \\
\hline $7^{\circ}$ & OS PREÇOS FISICO E FUTURO PODEM NÄO CONVERGIR & \\
\hline & GERANDO PREJUIZOS AO PRODUTOR & 19,44 \\
\hline $8^{\circ}$ & PERDA DE OPORTUNIDADE DE MAIORES LUCROS DURANTE & \\
\hline & A ENTRESSAFRA CASO O PREÇO SUBA & 6,94 \\
\hline $9^{\circ}$ & FALTA DE LIQÜIDEZ & 1,39 \\
\hline $10^{\circ}$ & FALTA DE ESTRUTURA DA BOLSA & 1,39 \\
\hline
\end{tabular}

Fonte: Dados da pesquisa

Anexo B Respostas assinaladas pelos traders às assertivas (verdadeiro, falso, em termos ou desconheço), em \%.

\begin{tabular}{|c|c|c|c|c|}
\hline \multirow{2}{*}{\multicolumn{5}{|c|}{ MERCADOS FUTUROS PODEM FACILITAR }} \\
\hline & & & & \\
\hline FINANCIAMENTOS PARA PRODUTORES & 78,69 & 6,56 & 8,20 & 6,56 \\
\hline DESUNIFORMIDADE FISCAL DIFICULTA & & & & \\
\hline \begin{tabular}{|l|} 
MERCADOS FUT \\
\end{tabular} & 69,84 & 9,52 & 12,70 & 7,94 \\
\hline É NECESSÁRIO "DESMISTIFICAÇÃO" DO & & & & \\
\hline ESPECULADOR PARA OS PRODUTORES & 54,84 & 14,52 & 17,74 & 12,90 \\
\hline MERCADOS AGRICOLAS NÁO FUNCIONAM F & & & & \\
\hline HÁ MUITA INTERVENÇĀO GOVERNAMENTAL & 41,94 & 16,13 & 35,48 & 6,45 \\
\hline MERCADOS NÄO FUNCIONAM POIS PROD & & & & \\
\hline PREFEREM VENDER NA ENTRESSAFRA & 25,8 & 32,2 & 38,71 & 3,23 \\
\hline $\mathrm{COOP}$ & & & & \\
\hline NOEXT & & & & \\
\hline
\end{tabular}

Fonte: Dados da pesquisa 
Anexo C Principais razões das possíveis dificuldades do desenvolvimento de um mercado futuro de milho no Brasil, segundo corretores (verdadeiro, falso, em termos ou desconheço), em \%.

\begin{tabular}{|c|c|c|c|c|c|}
\hline & & $\mathbf{V}$ & $\bar{F}$ & $T$ & $\mathrm{D}$ \\
\hline $1^{\circ}$ & DESCONFIANÇA DO PRODUTOR / FALTA DE DIVULGAÇAO & 81,82 & 4,55 & 13,64 & 0,00 \\
\hline $2^{\circ}$ & DESUNIFORMIDADE FISCAL & $60,87 \mid$ & 4,35 & $17,39 \mid$ & 17,39 \\
\hline $3^{\circ}$ & SONEGAÇĀO NO MERCADO FISICO DEVIDO A ALTA TAXAÇAO & 59,09 & 4,55 & 31,82 & 4,55 \\
\hline $4^{\circ}$ & FALTA DE TRADIÇAO & $59,09 \mid$ & 18,18 & $\mid 18,18$ & 4,55 \\
\hline $\mathbf{5}^{\circ}$ & DESCONHECIMENTO DO MERCADO FISICO POR PARTE DOS CORRETORES & 54,55 & $27,27 \mid$ & 13,64 & 4,55 \\
\hline $6^{\circ}$ & PREFERENCIA POR BOLSAS INTERNACIONAIS DEVIDO A ALTA & & & & \\
\hline & CORRELAÇĀO DE PREÇOS & 52,17 & 8,70 & 21,74 & 17,39 \\
\hline $7^{\circ}$ & DIFICULDADE PARA ATRAIR INVESTIDORES (ESPECULADORES) & 36,36 & 36,36 & 22,73 & 4,55 \\
\hline $8^{\circ}$ & IMPOSTOS SOBRE LUCROS NAS BOLSAS & 36,36 & 40,91 & 22,73 & 0,00 \\
\hline $9^{\circ}$ & INTERVENÇAOO GOVERNAMENTAL & 30,43 & $\mid 13,04$ & 47,83 & 8,70 \\
\hline $10^{\circ}$ & LOCAL DE ENTREGA/GRANDE EXTENSĀO TERRITORIAL & 27,27 & 27,27 & 45,45 & $\overline{0,00}$ \\
\hline$\overline{11^{\circ}}$ & DIFICULDADE PARA ATRAIR HEDGERS & 22,73 & 54,55 & $\mid 13,64$ & $\overline{9,09}$ \\
\hline $12^{\circ}$ & VOLUME FINANCEIRO PEQUENO & 18,18 & 27,27 & 36,36 & 18,18 \\
\hline $13^{\circ}$ & DIFICIL PADRONIZAÇÁO & $\mid 13,64$ & 59,09 & 9,09 & 18,18 \\
\hline
\end{tabular}

Fonte: Dados da pesquisa 
REFERÊNCIAS BIBLIOGRÁFICAS 


\section{REFERÊNCIAS BIBLIOGRÁFICAS}

ASSOCIAÇÃO NACIONAL DOS FABRICANTES DE RAÇÕES. Diferencial entre o alimento consumido e o mínimo necessário no ano de 1992. São Paulo, 1993a. 6p.

ASSOCIAÇÃO NACIONAL DOS FABRICANTES DE RAÇÕES. Estimativa de consumo de matérias-primas para fabricação de rações em função das projeções de produção do complexo dos produtos de origem animal (CPOA). São Paulo, 1993b. 20p.

ARAÚJO, N.B.; WEDEKIN, I.; PINAZZA, L.A. Complexo agroindustrial: o agribusiness brasileiro. São Paulo: Ortiz, 1990. 238p.

ATRASAS, A.L. Formação de preços no mercado futuro brasileiro. Viçosa, 1993. 104 p. Dissertação (M.S.) - Universidade Federal de Viçosa. 
BERALDO, A.D. A política de garantia de preços mínimos e a política de combate à inflação. Revista de Politica Agrícola, v.2, n.3, p.15-30, maio 1993.

BRANCO, A. Futuro da BM\&F cresce 45\%. Gazeta Mercantil, São Paulo, 17 jan. 1996. Finanças \& Mercados, p. B-16.

CHICAGO BOARD OF TRADE. Introduction to agricultural hedging. Chicago, 1985. 67p.

CHICAGO BOARD OF TRADE. Grains: production - processing - marketing. Chicago, 1992. $174 \mathrm{p}$.

COUTO, M.T.; HACKENHAAR, L. Estacionalidade na produção de milho. Preços Agrícolas, n. 91, p.4-9, maio 1994.

DAVIS, J.H.; GOLDBERG, R.A. A concept of agribusiness. Cambridge. Harvard University, 1957.

FARINA, E.M.M.Q.; ZILBERSZTAJN, D. Organização das cadeias agroindustriais de alimentos. São Paulo, 1993. p.187-208. 
FERRARI, L. Cinco empresas dominam $36 \%$ da avicultura: os cinco maiores grupos industriais brasileiros dobraram sua participação de mercado nos últimos 15 anos. Gazeta Mercantil, São Paulo, 16 abr. 1996. Finanças \& Mercados, p. B-18.

FORBES, L.F. Princípios básicos para aplicar nos mercados futuros. São Paulo: BM\&F, 1991. 40p. (Série introdutória 1)

FRICK, O.O. A cédula de produto rural e os mercados derivativos. Resenha BM\&F, n. 103, p. 69-78, jan./fev. 1995.

GALJART, B. Difusão cultural, modernização e subdesenvolvimento. In: SZMRECSANYI, T.; QUEDA, O. Vida rural e mudança social. São Paulo: Nacional, 1972. p.71-80.

HIERONYMUS, T.A. Economics of futures trading. Commodity Research Bureau, 1977. p.348.

JANK, M.S. Mercado internacional agrícola. Piracicaba, ESALQ, DESR, 1994. 
JANK, M.S.; LOPES, M.R.; ROSA, L.R.; BASTOS FILHO, G.S.; VIEIRA, L.C.; BRUM, A.L.; VILLWOCK, L.H.M.; POLI, B.T.C. Análise da competitividade das principais cadeias agroindustriais do Mercosul: trigo, soja, milho, suínos e aves. ljuí: FIDENE/UNIJUí, 1994. v.3.

KOHLS, A.L.; UHL, J.N. Marketing of agriculture products. New York: MacMillan, 1985. $621 \mathrm{p}$.

LOPES, M.R. Comercialização interna e externa da produção agrícola: principais problemas e sugestões. In: INSTITUTO DE PESQUISA ECONÔMICA APLICADA. Os principais problemas da agricultura brasileira: análise e sugestões. Rio de Janeiro, 1992. p.357-399.

LOPES, M.R. A política brasileira de preços mínimos. Conjuntura Econômica, p.37-40, set. 1994.

MALHEIROS, R.C.C. Análise de sistemas industriais. A filiére avícola de Santa Catarina. Florianópolis, 1991. Dissertação (Mestrado) Universidade Federal de Santa Catarina.

MARION, B.W. Vertical coordination and exchange arrangements: concepts and hypoteses. University of Wisconsin, 1976. (Monography, 2). 
MARQUES, P.V. Economia da integração vertical na avicultura de corte do estado de São Paulo. Piracicaba, 1991. 133p. Tese (Livre-docência) Escola Superior de Agricultura "Luiz de Queiroz", Universidade de São Paulo.

MARTIN, N.B.; GONÇALVES, J.S. Estudo das mudanças na distribuição regional e na composição da área agrícola brasileira no período 1970-93. Informações Econômicas, v.25, n.3, p.19-48, mar. 1995.

MELO, F.H. Agricultura brasileira: um novo horizonte de crescimento. Estudos Econômicos, v.21, n.3, p.299-317, set./dez. 1991.

MELO, F.H. Um balanço da crise agrícola do ano de 1995. Carta HM, p.8-14, mar 1996.

UM MERCADO para cada tipo. Notícias Abimilho, São Paulo, v. 2, n. 4, jun. 1995.

MILLER, D.C. - Handbook of research design and social measurement. 3. ed. New York: Longman, 1977. 
MORICOCHI, L.; FERREIRA, C.R.R.P.T.; VICENTE, J.R.; PIVA, L.H.O. Potencial de produção e produtividade da agricultura paulista: o caso do milho. Agricultura em São Paulo, v.36, n.1, p.127-48, 1989.

NÓBREGA, M.F.; GONÇALEZ, C.A.; MARTONE, C.L. Desenvolvimento dos mercado de futuros de commodities agrícolas e a tributação do ICMS. São Paulo: MCM Consultores Associados, 1990. 52p.

NUNES, D. Avicultura cresce em meio à crise. Correio do Povo, 21 mar. 1993. p.10-1.

OLIVEIRA, M. N. A. Situação e perspectivas do milho na região Sul e no Brasil. In: CONGRESSO NACIONAL DE MILHO E SORGO, 19., Porto Alegre, 1992. Anais. Porto Alegre: Secretaria da Agricultura do Rio Grande do Sul, 1992. p.40-68.

ORTMANN, G. F.; RASK, N.; STÜLP, V. J, Comparative costs in corn, wheat and soyabeans among major exporting countries. Columbus: The Ohio State University, Ohio Agricultural Researchand Development Center, 1989. (Research Bulletin, 1183).

PIVA, L.H.O; VICENTE, J.R.; MORICOCHI, L.; FERREIRA, C.R.R.P.T. Consumo de milho a nível de propriedade no Estado de São Paulo. In: CONGRESSO DE MILHO E SORGO, 18., Vitória, 1990. Anais. 
POWERS, M.J. Getting started in commodity future trading. lowa: Investor Publications, 1977.

REZENDE G.C. Inflação, preços mínimos e comercialização agrícola: a experiência dos anos 80. In: INSTITUTO DE PESQUISA ECONÔMICA APLICADA. Os principais problemas da agricultura brasileira: análise e sugestões. Rio de Janeiro, 1992. p.333-55.

SANTO, B.R.E.; DAMASCO, O.R.; NASSAR, A.M. Evolução e perspectivas econômicas da produção de milho no Brasil. Revista de Política Agrícola, v.3, n. 4, p.14-32, out./dez. 1994.

SANTOS FILHO, O. Estudo de uma anomalia do mercado: a queda dos negócios a termo de algodão na Bolsa de Mercadorias de São Paulo. São Paulo, 1982. 73 p. Dissertação (M.S.) - Escola de Administração de Empresas de São Paulo da Fundação Getúlio Vargas (EAESP/FGV).

SCHOUCHANA, F. Mercados futuros e de opções agropecuários: teoria e prática. São Paulo: Bolsa de Mercadorias \& Futuros, 1995. 54 p.

SOUSA, E.L.L. Sazonalidade dos preços do milho. Piracicaba, ESALQ/DESR, 1994. 20p. 
SOUSA, E.L.L.; MARQUES, P.V. Decisão entre vender e armazenar: um exemplo do milho na região de Uberaba, Minas Gerais, safra 1992/93. Informações Econômicas, v.25, n.1, p.75-83, jan. 1995.

SOUZA, N.J.; SANSON, J.R. A agroindústria brasileira do milho. Porto Alegre: Universidade Federal do Rio Grande do Sul, Faculdade de Ciências Econômicas, 1993. 96p.

SOUZA, W.A.; CRÓCOMO, F.C.; SOUSA, E.L.L. As relações contratuais da laranja no contexto do agribusiness. Piracicaba, ESALQ/DESR, 1994.

STÜLP, V.J. Tecnologia, custos e competitividade no Mercosul: Caso do trigo, soja, milho e arroz. Piracicaba: ESALQ/DESR, 1992. (Projeto Mercosul. Relatório A Agropecuária e o Mercosul).

TEIXEIRA, M.A. Mercados futuros: fundamentos e características operacionais. São Paulo: BM\&F, 1992. 53p.

THAME, A.C.M.; AMARO, A.A. Agroindústria e desenvolvimento no estado de São Paulo: aspectos dos contratos de compra e venda de produtos agrícolas. São Paulo: Instituto de Economia Agrícola, 1987. 25p. (Relatório de pesquisa, 35). 
TROMBETA, N.V. Sementes melhoradas impulsionam produção e produtividade. Anuário ABRASEM, Brasília, p.22, 1994.

TSUNECHIRO, A. O desempenho dos mercados a termo: os casos do café, soja e boi gordo na bolsa de mercadorias de São Paulo. Piracicaba, 1983. 123 p. Dissertação (M.S.) - Faculdade de Economia e Administração, Universidade de São Paulo.

VILLWOCK, L.H.M. Os impactos econômicos do Mercosul, sobre as cadeias de produção de trigo, soja, milho, suinos e aves. Porto Alegre, 1993. 222 p. Dissertação (M.S.) - Faculdade de Ciências Econômicas, Universidade Federal do Rio Grande do Sul. 
APÊNDICE 

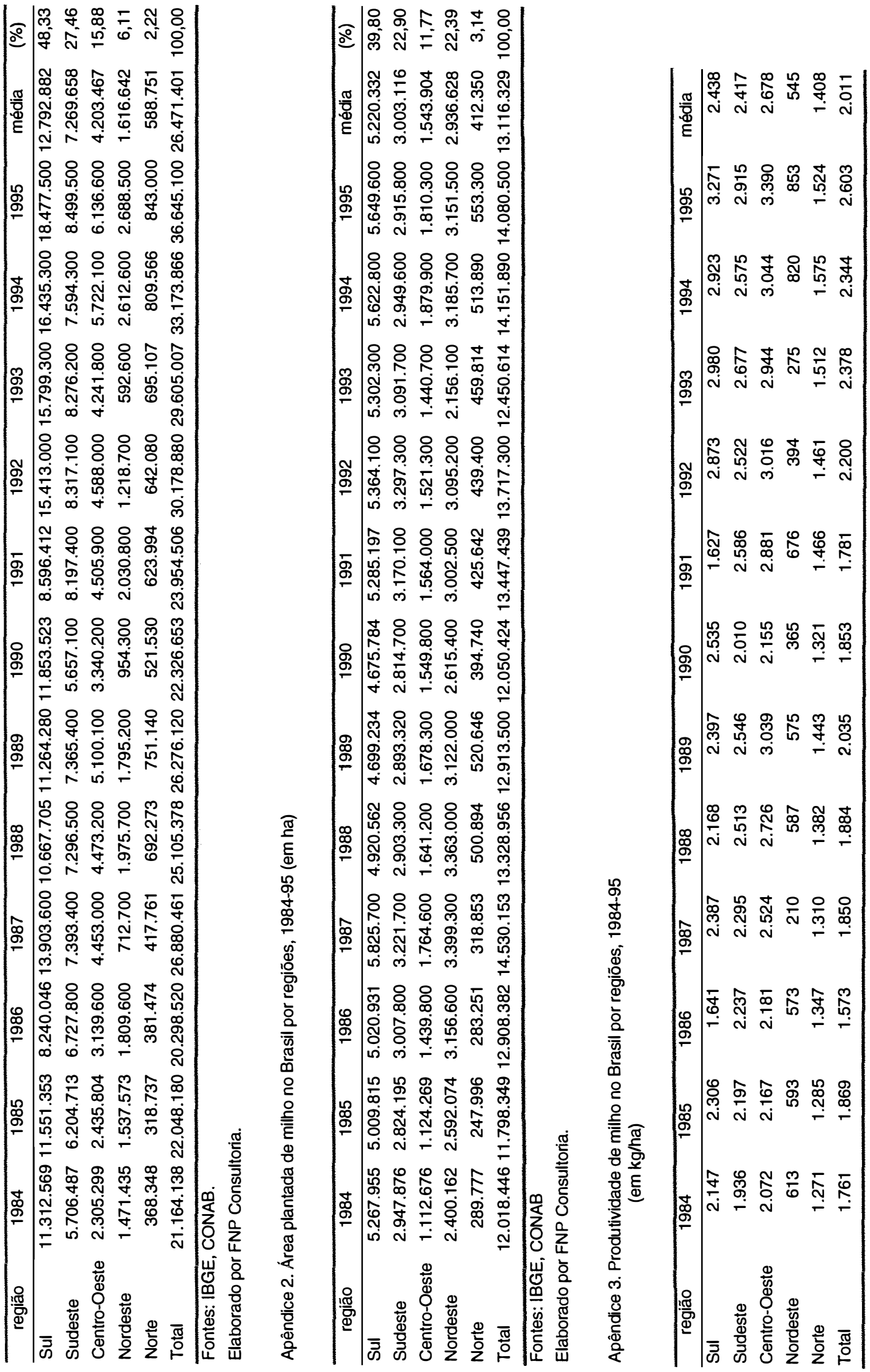
Apêndice 4 - Preços médios mensais dos principais produtos agropecuários (1987-96) - em R\$ base janeiro/96 (deflacionados pelo IGPDI/FGV).

\begin{tabular}{|c|c|c|c|c|c|c|c|}
\hline \multirow[t]{2}{*}{ mês } & milho & soja & boi gordo & cana-de-açúcar & algodão & café beneficiado & feijão \\
\hline & sc/60kg & sc/60kg & $\underset{(15 \mathrm{~kg})}{@}$ & $\mathrm{t}$ & $\underset{(15 \mathrm{~kg})}{@}$ & $\mathrm{sc} / 60 \mathrm{~kg}$ & $\begin{array}{c}\mathrm{sc} / 60 \\
\mathrm{~kg}\end{array}$ \\
\hline jan & 11,95 & 19,19 & 34,05 & 15,80 & 8,97 & 130,24 & 48,20 \\
\hline fev & 10,92 & 18,51 & 31,65 & 16,49 & 10,01 & 123,67 & 50,94 \\
\hline mar & 9,68 & 17,18 & 30,54 & 15,97 & 9,58 & 123,82 & 60,64 \\
\hline$a b r$ & 9,13 & 16,33 & 30,90 & 15,29 & 9,43 & 120,82 & 64,02 \\
\hline maio & 9,44 & 16,82 & 30,70 & 15,99 & 9,19 & 126,09 & 67,20 \\
\hline jun & 9,79 & 17,34 & 30,68 & 15,73 & 8,67 & 119,39 & 65,64 \\
\hline jul & 9,49 & 17,42 & 31,75 & 15,31 & 8,19 & 114,67 & 57,47 \\
\hline ago & 10,60 & 17,72 & 35,43 & 15,47 & 8,28 & 112,20 & 50,74 \\
\hline set & 10,58 & 17,97 & 34,91 & 15,67 & 8,83 & 115,25 & 47,02 \\
\hline out & 10,92 & 18,13 & 34,21 & 15,67 & 9,07 & 110,09 & 51,97 \\
\hline nov & 11,69 & 18,32 & 33,96 & 15,57 & 9,24 & 107,58 & 53,77 \\
\hline dez & 11,65 & 18,87 & 30,68 & 15,66 & 8,49 & 103,90 & 46,80 \\
\hline
\end{tabular}

Fonte: FEALQ/CEPEA 

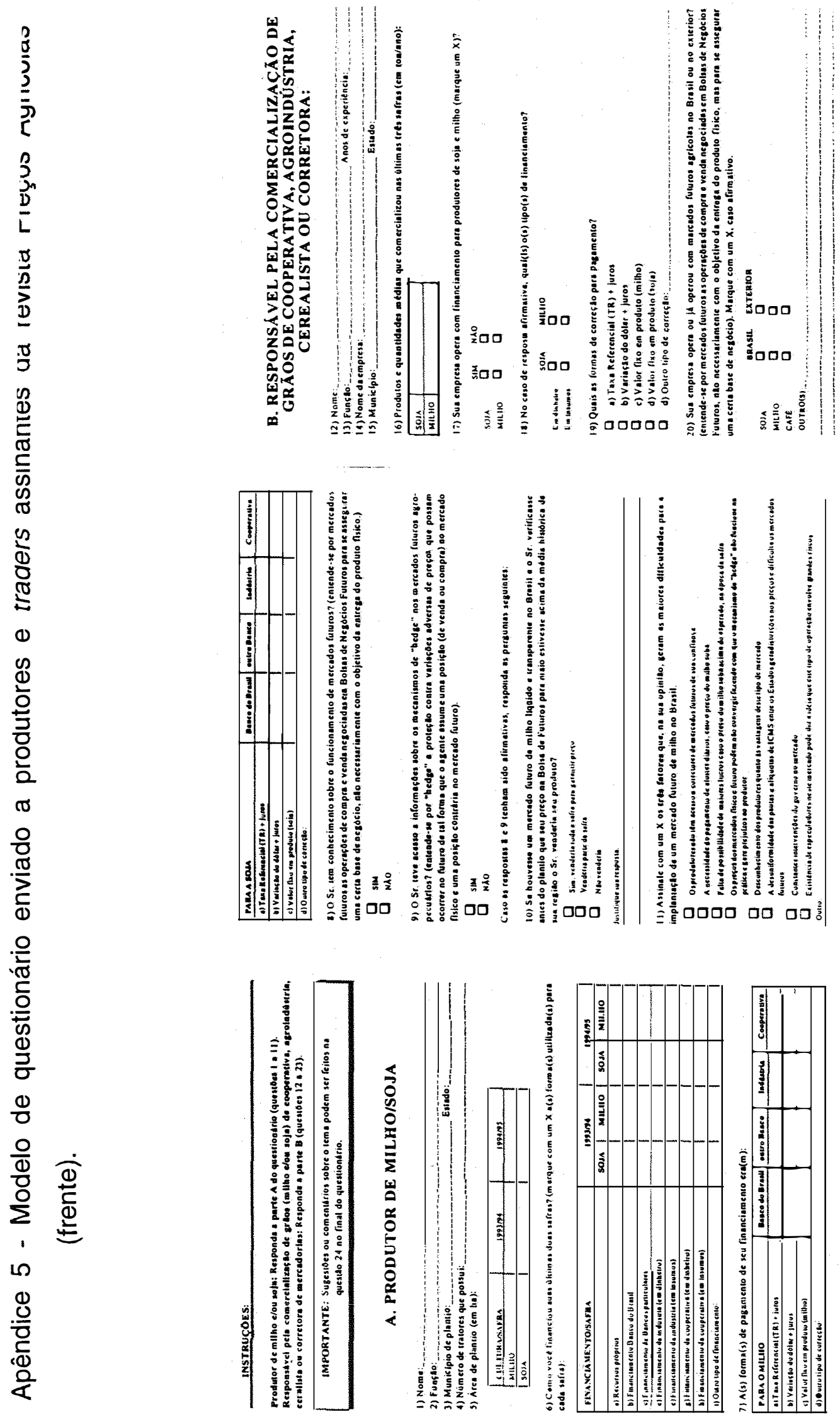







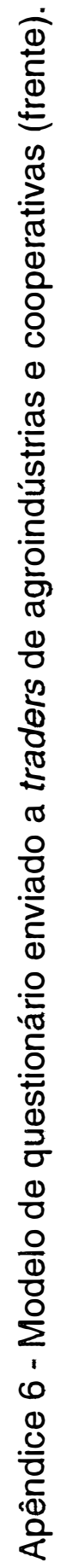
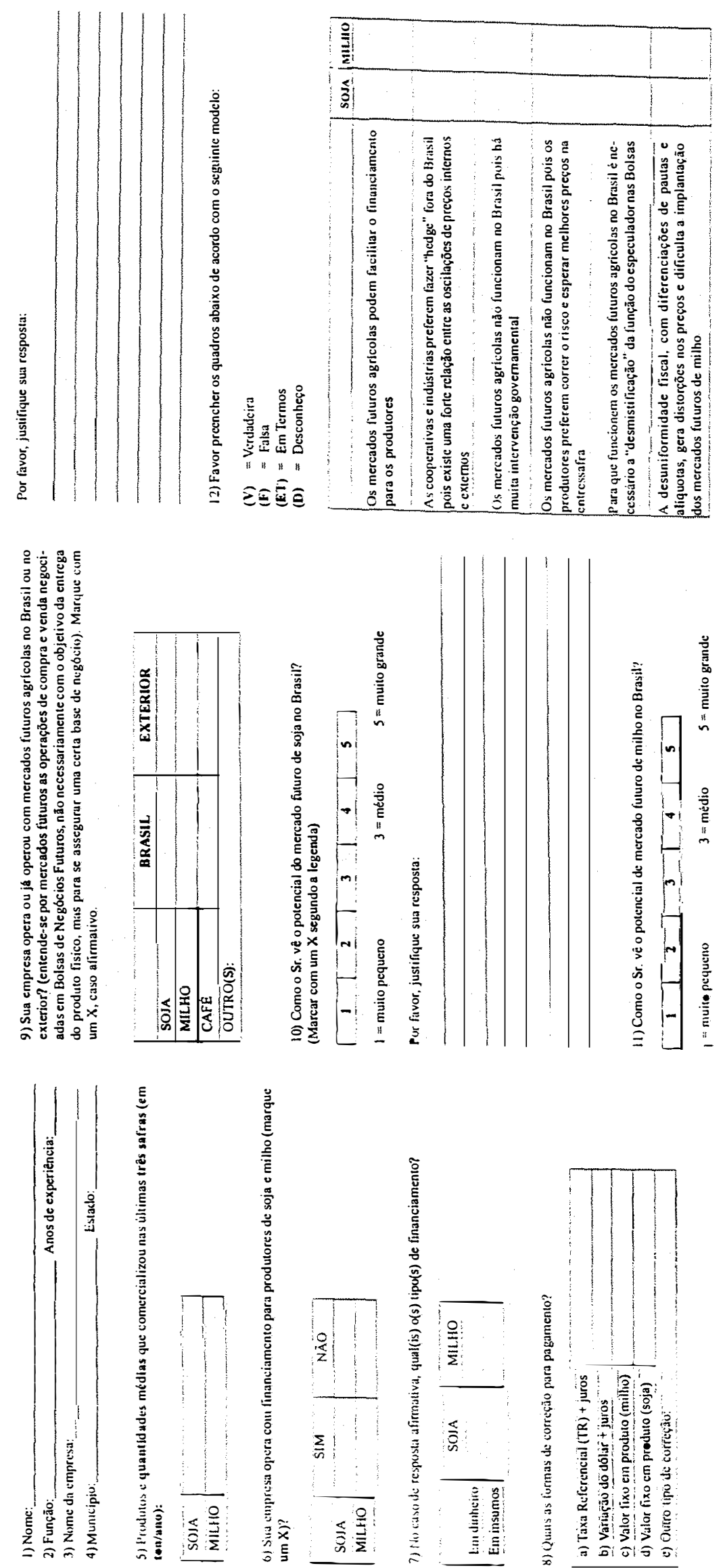

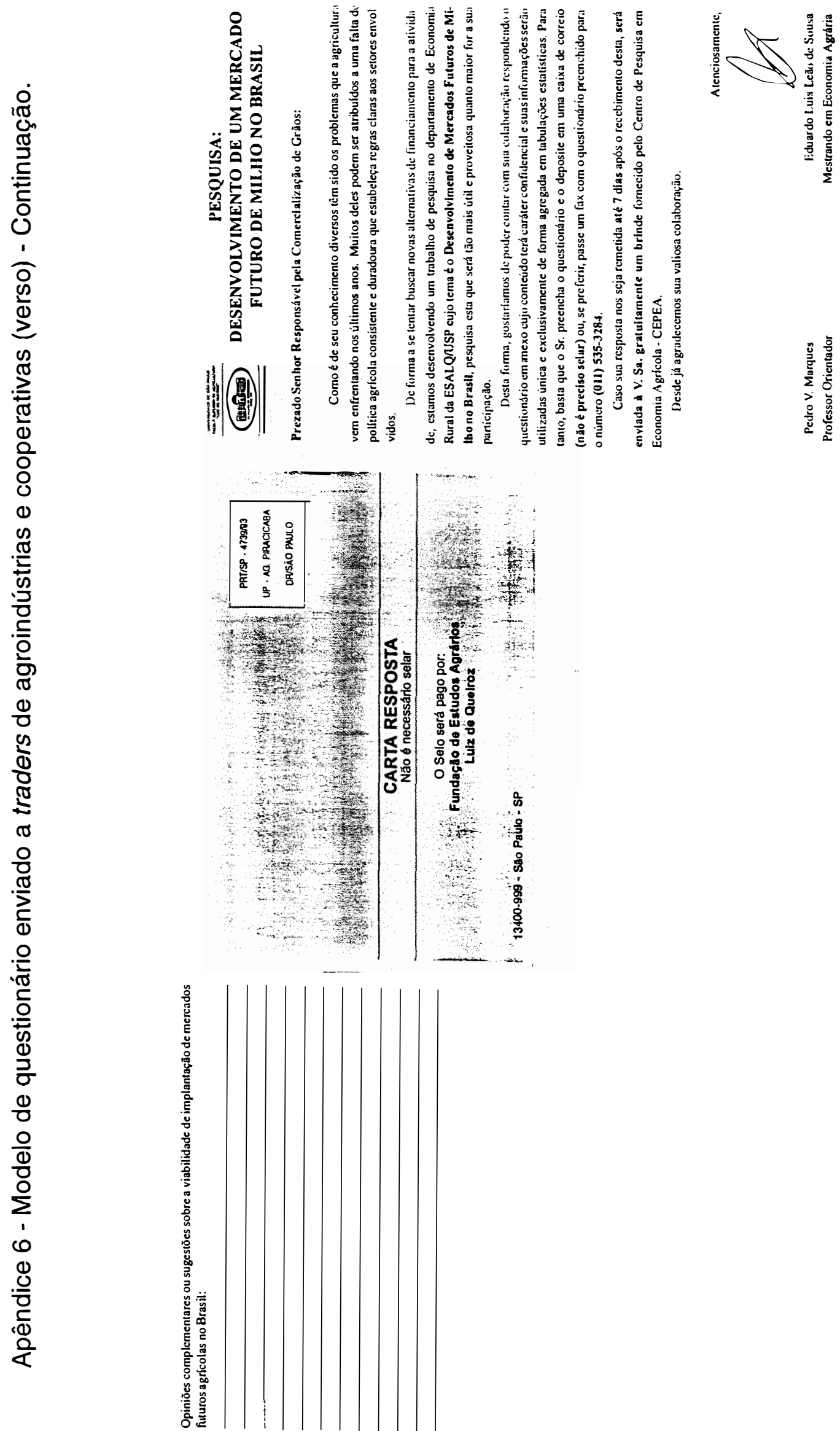


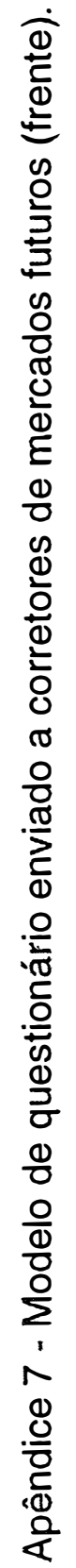
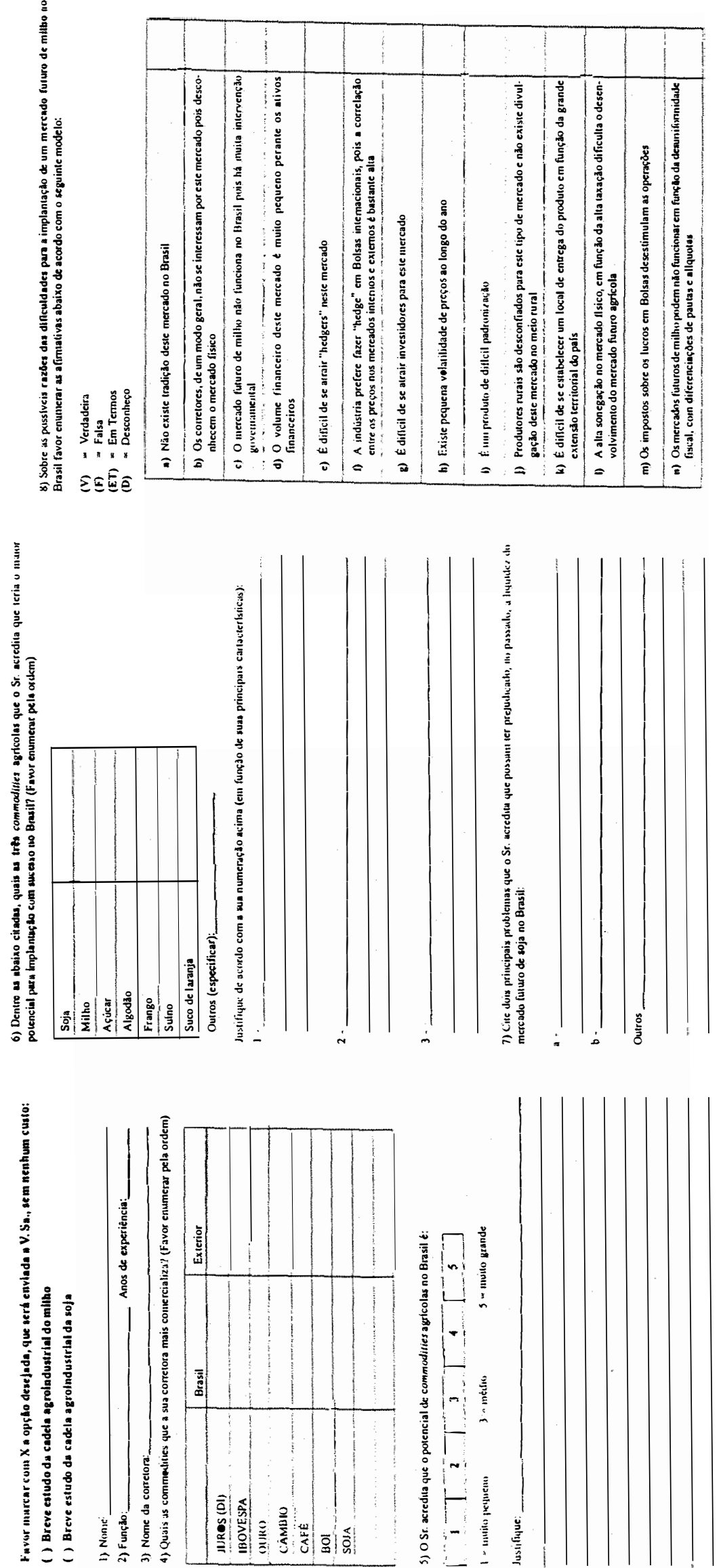


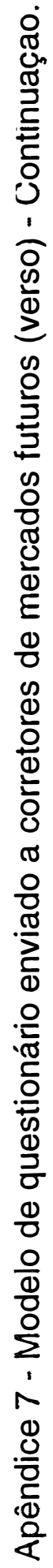
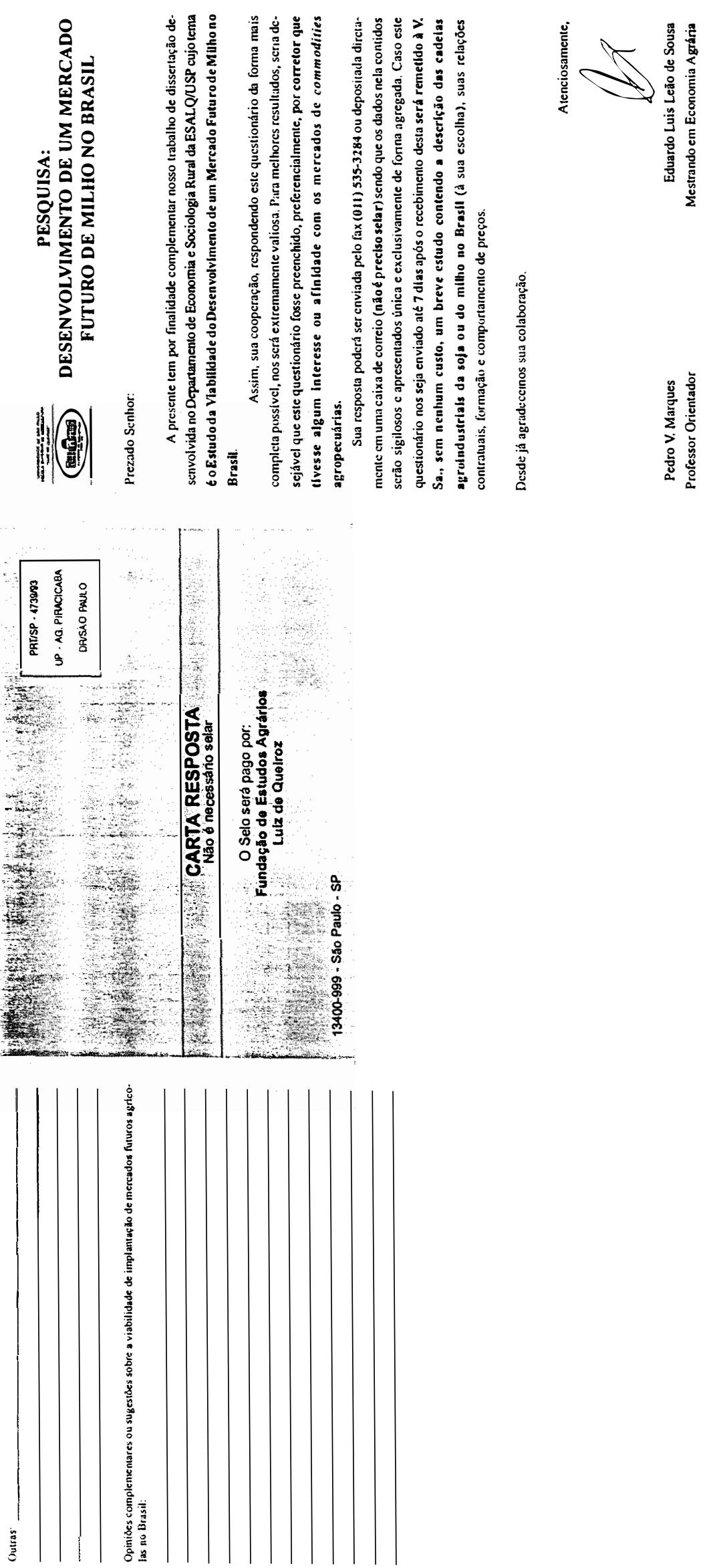